\title{
Marine Isonitriles and Their Related Compounds
}

\author{
Jens Emsermann ${ }^{\dagger}$, Ulrich Kauhl ${ }^{\dagger}$ and Till Opatz ${ }^{*}$ \\ Received: 30 November 2015; Accepted: 23 December 2015; Published: 14 January 2016 \\ Academic Editor: Orazio Taglialatela-Scafati \\ Institute of Organic Chemistry, Johannes Gutenberg-University Mainz, Duesbergweg 10-14, 55128 Mainz, \\ Germany; emsermann@uni-mainz.de (J.E.); kauhl@uni-mainz.de (U.K.) \\ * Correspondence: opatz@uni.mainz.de; Tel.: +49-6131-39-24443; Fax: +49-6131-39-22338 \\ + Both authors contributed equally to this work.
}

\begin{abstract}
Marine isonitriles represent the largest group of natural products carrying the remarkable isocyanide moiety. Together with marine isothiocyanates and formamides, which originate from the same biosynthetic pathways, they offer diverse biological activities and in spite of their exotic nature they may constitute potential lead structures for pharmaceutical development. Among other biological activities, several marine isonitriles show antimalarial, antitubercular, antifouling and antiplasmodial effects. In contrast to terrestrial isonitriles, which are mostly derived from $\alpha$-amino acids, the vast majority of marine representatives are of terpenoid origin. An overview of all known marine isonitriles and their congeners will be given and their biological and chemical aspects will be discussed.
\end{abstract}

Keywords: isonitriles; marine natural products; terpenes; isothiocyanates; formamides; antibiotics; carbonimidic dichlorides; malaria

\section{Introduction}

The isonitrile group is a unique functionality as it is isoeletronic to carbon monoxide and shows a high affinity towards transition metals which might cause toxic effects in vivo. Moreover, the isonitrile carbon has an uncommon valency state and the exergonic transformation of isonitriles to amides or related structures in countless named or unnamed two- or multi-component reactions such as Passerini- or Ugi-reactions is paramount. Most isonitriles employed in chemical reactions are man-made and are frequently derived from the corresponding amines. On the other hand, the ocurrence of the isonitrile function in natural products is still regarded as a curiosity by many due to its potential reactivity with diverse nucleophiles and electrophiles.

Until 1973, the terrestrial isonitrile xanthocillin (1) was the only known natural isonitrile which was isolated by Rothe in 1950 from Penicillium notatum (Figure 1) [1]. Then, Cafieri et al. isolated the first marine isonitrile, axisonitrile-1 (2), together with axisothiocyanate-1 (3) from the marine sponge Axinella cannabina collected in the Bay of Taranto (Italy) [2]. In contrast to the terrestrial isonitriles, which are mostly derived from amino acids, the majority of marine isonitriles have a terpenoid origin. Not much later, other research groups reported the isolation of further marine isonitriles and related compounds and new representatives are constantly being identified [3,4]. To date, about 200 isonitrile natural products are known and $63 \%$ of them originate from marine sources.

Early on, Fattorusso et al. and Burreson et al. observed that the isonitriles occurred usually with the corresponding formamide and isothiocyanate compounds [5,6]. Additionally, structurally closely related cyanates, thiocyanates and carbonimidic dichlorides have been reported, albeit in smaller numbers. The marine isonitriles can be divided into four groups, the sesquiterpenoids (Section 2.1), the diterpenoids (Section 2.2), carbonimidic dichlorides (Section 2.3) and miscellaneous structures (Section 2.4) which can not be classified into the previous groups. The sesquiterpenoids only bear 
a single nitrogenous functional group and some of them are additionally oxygenated. However, the diterpenoids can possess a higher degree of functionalization. The most complex compounds are the kalihinols which are functionalized with a tetrahydrofuran- or a tetrahydropyran-ring along with hydroxy, chloro or olefinic moieties. Marine isonitriles have been isolated from sponges and from nudibranchs but the latter are probably mostly of dietary origin.<smiles>CC(=Cc1ccc(O)cc1)C(C#N)=Cc1ccc(O)cc1</smiles>

1<smiles>[R]C(C(C)C)[C@H]1CC[C@]2(C)CCCC(=C)[C@@H]12</smiles>

$2 \mathrm{R}=\mathrm{NC}$

$3 \mathrm{R}=\mathrm{NCS}$

Figure 1. Xanthocillin (1), axisonitrile-1 (2) and axisothiocyanate (3).

The first review about isonitrile natural products was published by Edenborough and Herbert in 1988 [7] while the first review on marine isonitriles and related compounds by Chang and Scheuer appeared five years later [8]. Chang also published a review on marine and terrestrial isonitriles along with their congeners in 2000 [9]. In the same year Garson et al. published a review about the structures, biosynthesis and ecology of marine isonitriles [10]. Reviews about the biosynthesis of marine isonitriles were published by Garson in 1989 [11], by Chang and Scheuer in 1990 [12], and by Garson in 1993 [13]. An update of Garson's 1988 review appeared in 2004 [14]. A review about isolation, biological activity and chemical synthesis of isocyanoterpenes was published in 2015 by Schnermann and Shenvi [15].

Since the number of known marine-derived isonitrile natural products has increased significantly since 2000, we intend to give the reader a complete overview of all members of this compound class known to date. In addition, aspects about biosynthesis and bioactivity will be discussed.

\section{Marine Isonitriles and Related Compounds}

Most marine isonitriles and their formamide and isothiocyanate congeners are either sesquiterpenoids (Section 2.1) or diterpenoids (Section 2.2). The sesquiterpenoids have only one nitrogenous functional group whereas the diterpenes bear up to three functional groups. Carbonimidic dichlorides (Section 2.3), which originate from the corresponding isonitriles or isothiocyanates, are also known. Finally, there are some miscellaneous structures (Section 2.4) which can not be classified in the previous sections.

\subsection{Sesquiterpenoids}

Sesquiterpenoids constitute the largest subgroup of the marine isonitriles and their related compounds (-NCS, $-\mathrm{NHCHO},-\mathrm{SCN},-\mathrm{NCO},-\mathrm{N}=\mathrm{CCl}_{2}$ ) which in combination could be termed "isonitriloids" due to their close biogenetic relationship with the flagship isonitriles. Most of the isonitriles of this class have the molecular formula $\mathrm{C}_{15} \mathrm{H}_{25} \mathrm{NC}$ but they can be subdivided into nine groups based on the type of their molecular skeleton (Figure 2). To date, over 190 sesquiterpenes bearing one of the above-mentioned nitrogenous functions are known, among them are nine axanes (Ax2-Ax10), 32 eudesmanes (Eu2-Eu33), 33 cadinanes/amorphanes (Ca2-Ca34), 19 spiroaxanes (Sp2-Sp20), 14 aromadendranes (Ar2-Ar16), eight epimaalianes (Ep2-Ep9), 14 pupukeananes (Pu2-Pu15), 35 bisabolanes (Bi2-Bi36), nine guaianes (Gu2-Gu10) and 17 further sesquiterpenoids (Fu1-Fu17). 


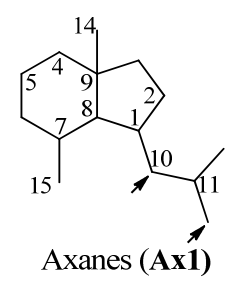

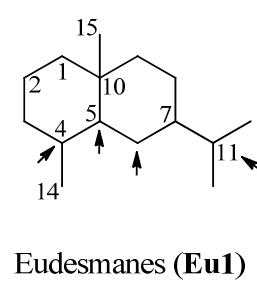
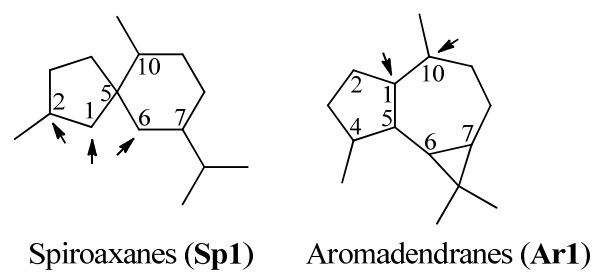

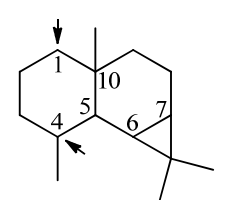

Epimaalianes (Ep1)

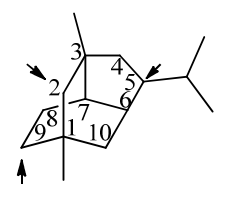

Pupukeananes (Pu1)

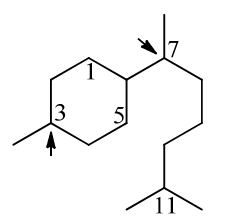

Bisabolanes (Bi1)

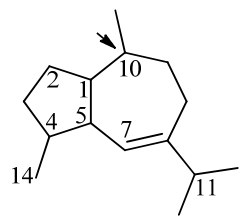

Guaianes (Gu1)

Figure 2. Skeletal-types of sesquiterpenoids (arrows indicate potential attachment points of the nitrogenous function).

\subsubsection{Axanes}

As already mentioned in the introduction, the first marine isonitrile, axisonitrile-1 (Ax2), was isolated by Cafieri et al. from the marine sponge Axinella cannabina, collected in the Bay of Taranto (Italy), along with the corresponding axisothiocyanate-1 (Ax3), in 1973 (Figure 3) [2]. The name is based on the genus of the marine sponge, Axinella cannabina, and the functional group "isonitrile" or "isothiocyanate", respectively. The corresponding formamido compound axamide-1 (Ax4) was isolated by the same group one year later [5]. Further examination of the extracts of Axinella cannabina led to some minor sesquiterpenoids, which could be identified as axisonitrile-4 (Ax5), axisothiocyanate-4 (Ax6) and axamide-4 (Ax7) [16]. The absolute configuration of axisonitrile-1 (Ax2), axisonitrile-4 (Ax5) and their related compounds was determined by X-ray crystallography and by CD-spectroscopy [17] but the configuration at C-10 was initially incorrectly assigned and had to be revised later [18].

Cavernoisonitrile (Ax8), (-)-cavernothiocyanate (Ax10) and 10-isothiocyanato-11-axene (Ax9) were isolated from the marine sponge Acanthella cavernosa and the nudibranch Phyllidia ocellata, collected at the Hachijo-jima Island (Japan) by Fusetani et al. $[19,20]$.<smiles>CC(C)CC1=CCC2(C)CCCC(C)C12</smiles>

Ax1<smiles>C=C1CCC[C@]2(C)CC[C@@H]3C(C)(C)OC3(N)[C@H]12</smiles>

Ax8<smiles>[R]C(C(C)C)[C@H]1CC[C@]2(C)CCCC(=C)[C@H]12</smiles>

Ax2 R $=$ NC $\operatorname{Ax} 3 \mathrm{R}=\mathrm{NCS}$ Ax4 R $=$ NHCHO<smiles>C=NC(C(=C)C)C1CCC[C@]2(C)CCC[C@H](C)[C@H]12</smiles>
Ax9<smiles>[R]C(C)=C(C)C1CCC2(C)CCCC(=C)C12</smiles>

$$
\text { Ax5 R }=\text { NC }
$$$$
\text { Ax6 R }=\text { NCS }
$$$$
\text { Ax7 R }=\text { NHCHO }
$$<smiles>C/C(=C\[C@@H]1CC[C@@]2(C)CCC[C@H](C)[C@H]12)C[Se]</smiles>

Ax10

Figure 3. Axanes.

\subsubsection{Eudesmanes}

The first eudesmane-type isonitrile, acanthellin-1 (Eu2), was isolated from the sponge Acanthella acuta by Minale et al., collected in the Bay of Naples, Italy, in 1974 (Figure 4) [3]. 
The corresponding isothiocyanate Eu3 and formamide Eu4 were found together with acanthellin-1 (Eu2) ten years later by Ciminiello et al. in a sample of Axinella cannabina [21]. In the same sample, these authors also detected the isonitrile Eu5, the isothiocyanate Eu6 and the formamide Eu7 [21]. The same group also reported the isolation of the isonitrile $\mathbf{E u 8}$, isothiocyanate $\mathbf{E u} \mathbf{9}$ and the formamide Eu10 from the sponge Axinella cannabina [22]. Furthermore, the isonitrile Eu8 and the isothiocyanate Eu9 were isolated from Acanthella acuta [22].<smiles></smiles>

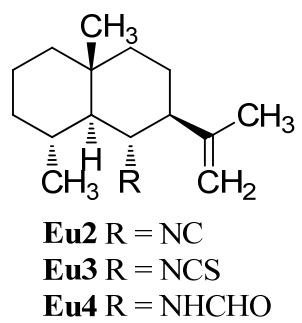

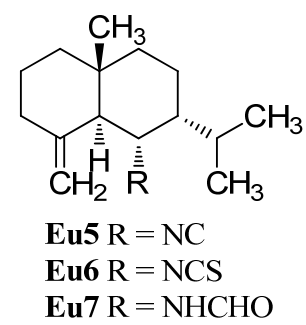<smiles>[R][C@@H]1[C]2C(=C)CCC[C@@]2(C)CC[C@@H]1C(C)C</smiles>

Eu8 R $=$ NC

Eu9 R = NCS

Eu10 R = NHCHO<smiles>[R]C1[C@H](C(C)C)CC[C@]2(C)CCCC(=C)[C@@]12C</smiles>

Eu11 $R=N C$

Eu12 $R=$ NCS

Eu13 R = NHCHO

Eu14 $\mathrm{R}=\mathrm{NHCO}_{2} \mathrm{Me}$<smiles>C=C1CCC[C@]2(C)CC[C@H](C(C)C)[C@H](NC(=O)N[C@H]3[C@@H](C(C)C)CC[C@]4(C)CCCC(=C)[C@H]34)[C@H]12</smiles><smiles>[R]C(C)(C)[C@H]1C=C2[C@@H](C)CCC[C@]2(C)CC1</smiles>

Eu16 R = NC

Eu17 R $=$ NCS

Eu18 R = NHCHO<smiles>[R]C1(C)CCC[C@]2(C)CC[C@@H](C(=C)C)C[C@]12C</smiles>

Eu19 R = NC

Eu20 R $=$ NCS

Eu21 R = NHCHO<smiles>CC(C)C1=C[C@@]2(C#N)[C@H](C)CCC[C@]2(C)CC1</smiles><smiles>CC(C)C1=C[C@@]2([N])[C@H](C)CCC[C@]2(C)CC1</smiles>

Eu23<smiles>C=C(C)C1CC[C@]2(C)CCCC(C)([N+](=O)[O-])[C@@H]2C1</smiles>

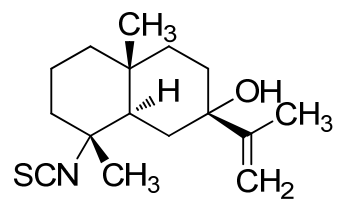

Eu25<smiles>C=C(C)C1(OO)CC[C@@H](C)[C@H]2CCCC(C)(N=[Se])[C@@H]2C1</smiles>

Eu26<smiles>CC(C)C1=CC[C@]2(C)CCC[C@](C)(NC=O)[C@H]2C1</smiles>

Eu27<smiles>CC1(C)CCC[C@]2(C)[C@@H](N=O)[C@H](C(C)(C)O)CC[C@@H]12</smiles>

Eu28

Figure 4. Eudesmanes.

In 1993, Burgoyne et al. reported the isolation of acanthene B (Eu12) from an Acanthella sponge and acanthene $C$ (Eu13) from the nudibranch Cadlina luteomarginata but they were unable to isolate the parent isonitrile Eu11 [23]. However, this compound, halichonadin C (Eu11), was obtained from the sponge Halichondria sp. from Unten Port, Okinawa, Japan [24]. In this sample, Ishiyama et al. also found halichonadin B (Eu14) with a carbamate group and halichonadin A (Eu15), a dimer with two eudesmane skeletons bridged by a urea linkage [24].

The previous compounds all carry their nitrogenous function at C-6 but compounds with the function at C-4 and C-11 are also known. 11-Isocyano-7 $\beta$-H-eudesm-5-ene (Eu16), the corresponding 11-isothiocyano-7 $\beta$-H-eudesm-5-ene (Eu17), as well as 11-formamido-7 $\beta$ - $H$-eudesm-5-ene (Eu18) were isolated by Ciminiello et al. in 1987 from the sponge Axinella cannabina [25]. The compounds were also found in the Caribbean sponge Axinyssa ambrosia [26]. Moreover the isonitrile Eu16 was obtained from the nudibranch Phyllidiella pustulosa [27] and together with the isothiocyanato 
compound Eu17 from the sponge Acanthella sp. and the nudibranch Cadlina luteomarginata [23]. The isothiocyanato compound Eu17 is also one of several sesquiterpenoids isolated from the sponge Acanthella pulcherrima [28]. 11-Isothiocyano-7 $\beta$-H-eudesm-5-ene (Eu17) did not show cytotoxity against cultured KB-3 cells $\left(\mathrm{IC}_{50}>20 \mu \mathrm{g} / \mathrm{mL}\right)$ but moderate antimalarial activity against Plasmodium falciparum was observed (chloroquine-sensitive strain D6: $\mathrm{IC}_{50}=2240 \mathrm{ng} / \mathrm{mL}$, chloroquine-resistant strain W2: $\left.\mathrm{IC}_{50}=610 \mathrm{ng} / \mathrm{mL}\right)[29]$.

4-Isocyanatoeudesm-11-ene (Eu19) and 4-formamidoeudesm-11-ene (Eu21) have been isolated from the Caribbean sponge Axinyssa ambrosia [26]. The appropriate 4-isothiocyanatoeudesm-11-ene (Eu20) was found in the sponge Acanthella klethra [30] and later also in an unidentified sponge of the genus Acanthella, the nudibranch Cadlina luteomarginata [23], the sponge Acanthella cavernosa [31,32] and the sponge Axinyssa Isabela [33]. Similar to isothiocyanate Eu17, 4-isothiocyanatoeudesm-11-ene (Eu20) displayed a moderate antimalarial activity against Plasmodium falciparum (chloroquine-sensitive strain D6: $\mathrm{IC}_{50}=4000 \mathrm{ng} / \mathrm{mL}$, chloroquine-resistant strain $\mathrm{W} 2: \mathrm{IC}_{50}=550 \mathrm{ng} / \mathrm{mL}$ ) and no cytotoxic activity against $\mathrm{KB}-3$ cells $\left(\mathrm{IC}_{50}>20 \mu \mathrm{g} / \mathrm{mL}\right)$ [29].

Stylostelline $(\mathrm{Eu} 22)\left([\alpha]_{\mathrm{D}}=+23^{\circ}\left(\mathrm{CHCl}_{3}, \mathrm{c}=2\right)\right)$, isolated from the Stylotella sp. and collected in the Southeast of New-Caledonia [34], is one of only two marine isonitriloids with the nitrogenous function attached to $\mathrm{C}-5$. The other known isonitrile is the corresponding enantiomer ent-stylotelline (Eu23) $\left([\alpha]_{\mathrm{D}}=-47^{\circ}\left(\mathrm{CHCl}_{3}, \mathrm{c}=1.7\right)\right)$ which was isolated from the nudibranch Phyllidiella pustulosa [35].

The isothiocyanate Eu24 is a C-7 epimer of compound Eu20 and was also isolated from the marine sponge Acanthella klethra [30]. The inversion of configuration at C-7 leads to a drastic reduction of the antimalarial activity against Plasmodium falciparum (chloroquine-sensitive strain D6: $\mathrm{IC}_{50}>10 \mu \mathrm{g} / \mathrm{mL}$, chloroquine-resistant strain $\mathrm{W} 2: \mathrm{IC}_{50}>10 \mu \mathrm{g} / \mathrm{mL}$ ) [29].

With only few exceptions, the nitrogenous function is the only heteroatom moiety in these secondary metabolites. However, Zubia et al. investigated the metabolites of the sponge of the genus Axynissa, collected in the Gulf of California (Mexico). In these samples, the hydroxylated axinisothiocyanate $\mathrm{M}(\mathbf{E u 2 5})$ and the hydroperoxide axinisothiocyanate $\mathrm{N}$ (Eu26) were identified [33].

In 2008, Lan et al. investigated extracts of the sponge Axinyssa sp., collected from the South Chinese Sea, and isolated the hitherto unknown formamides 4-formamidoeudesm-7-ene (Eu27) and the hydroxylated 4-formamidoeudesman-11-ol (Eu28) [36]. 4-Formamidoeudesm-7-ene (Eu27) exhibited significant cytotoxic activity against the human cancer cell lines CNE-2 $\left(\mathrm{IC}_{50}=13.8 \mu \mathrm{g} / \mathrm{mL}\right)$, HeLa $\left(\mathrm{IC}_{50}=7.5 \mu \mathrm{g} / \mathrm{mL}\right)$ and LO2 $\left(\mathrm{IC}_{50}=38.0 \mu \mathrm{g} / \mathrm{mL}\right)[36]$.

In addition to halichonadin A (Eu15), there are some other dimeric sesquiterpenoids with the eudesmane skeleton (Figure 5). Halichonadin E (Eu29) is an unsymmetrical dimer with one eudesmane and one aromadendrane (see Section 2.1.5) unit linked by a bridging urea moiety and was isolated from the Halichondria sp. by Kozawa et al. [37]. The same group isolated and identified the halichonadins G (Eu30), H (Eu31), I (Eu32) and J (Eu33) [38]. The halichonadins G-I are all dimeric sesquiterpenoids with two eudesmane skeletons with an 2-[1-(2-amino-2-oxoethyl)ureido]acetate linkage (Eu30), a 2-hydroxymalonamide linkage (Eu31) and an urea linkage (Eu32). Halichonadin $\mathrm{J}$ (Eu33) is a sesquiterpenoid with an eudesmane skeleton connected to 2-phenethylamine through a urea bridge.

\subsubsection{Cadinanes}

The first cadinane- or amorphane-type isonitrile Ca2 was isolated along with the corresponding 10-isothiocyanato-4-amorphene (Ca3) and 10-formamido-4-amorphene (Ca4) from the sponge Halichondria sp. by Burreson et al. in 1975 (Figure 6). [6,39,40].

10-Isothiocyanato-4-amorphene (Ca3) displayed a weak antiplasmodial activity against Plasmodium falciparum (strains $\mathrm{K} 1$ and $\mathrm{NF54}, \mathrm{IC}_{50}=5.7 \mu \mathrm{M}$ ) [41]. Furthermore, 10-isocyano-4-amorphene $\left(\mathbf{C a} 2, \mathrm{IC}_{50}=7.2 \mu \mathrm{g} / \mathrm{mL}\right)$ and 10-isothiocyanato-4-amorphene $\left(\mathbf{C a} 3, \mathrm{IC}_{50}=0.70 \mu \mathrm{g} / \mathrm{mL}\right)$ showed potent antifouling activity against larvae of the acorn barnacle Balanus amphitrite [42]. Later, the isonitrile Ca2 was 
isolated from a sponge of the genus Axinyssa [43] and along with the isothiocyanate Ca3 from nudibranchs of the genus Phyllidiidae [42].

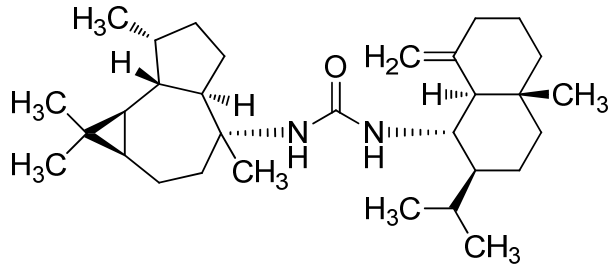

Eu29<smiles>C=C1CCCC2(C)CC[C@H](C(C)C)C(NC(=O)C(O)C(=O)N[C@H]3C(C(C)C)CCC4(C)CCCC(=C)[C@H]34)[C@H]12</smiles>

Eu31

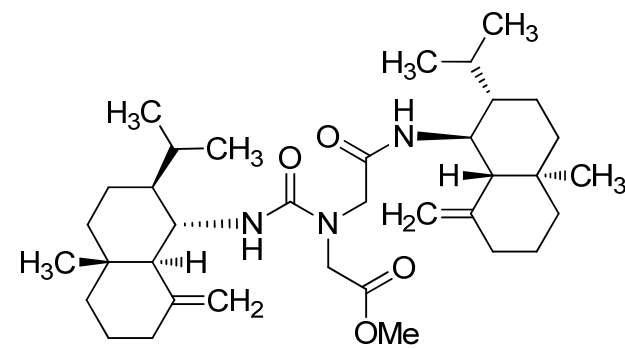

Eu30<smiles>C=C1CCCC2(C)CC[C@H](C(C)C)C(NC(=O)NC(C)(C)[C@@H]3C=C4C(C)CCCC4(C)CC3)[C@H]12</smiles>

Eu32<smiles>C=C1CCC[C@]2(C)CC[C@H](C(C)C)[C@H](NC(=O)NCCc3ccccc3)[C@H]12</smiles>

Eu33

Figure 5. Dimeric sesquiterpenoids with eudesmane skeleton.

Further investigation by Ciminiello et al. of extracts from the sponge Axinella cannabina led to the identification of minor metabolites isonitrile Ca5, isothiocyanate Ca6 and the formamide Ca7 [44]. The isothiocyanate compound halipanicine (Ca9) was found by Nakamura et al. in the sponge Halichondria panacea, collected from Okinawan Island, Japan [45]. The corresponding isonitrile Ca8 and formamide Ca10 were absent in this sponge and were isolated later from the sponge Axinyssa aplysinoides from Palau [46].

There are numerous cadinanes for which the complete isonitriloid triples of isonitrile, isothiocyanate, and formamide have not yet been found but where only one of the isonitriloid species is known. The isonitrile $4 \alpha$-isocyano-9-amorphene (Ca11) was isolated by Fusetani et al. from specimens of the nudibranch Phyllidia pustulosa, which were collected off Hachijo-jima Island, Japan [47]. The same team isolated the isonitrile $10 \alpha$-isocyano-4-amorphene (Ca12) from the sponge Acanthella cf. cavernosa and the nudibranch Phyllidia ocellata [19]. 10-Isocyano-4-cadinene (Ca13) was isolated by Okino et al. from the nudibranch Phyllidia pustulosa from Kamikoshiki-jima Island, Japan, in 1996 [42]. This isonitrile also displayed potent antifouling activity against larvae of the acorn barnacle Balanus amphitrite $\left(\mathrm{IC}_{50}=0.14 \mu \mathrm{g} / \mathrm{mL}\right)$ [42]. Four years later, the corresponding 10-isothiocyanato-4-cadinene (Ca14) was isolated from the tropical marine sponge Acanthella cavernosa [31]. Its absolute configuration was elucidated by enantioselective synthesis of both optical antipodes [48]. The isothiocyanate Ca15, a C-1 epimer of isothiocyanate Ca6, was isolated from a specimen of the sponge Acanthella pulcherrima, collected off Weed Reef, Darwin, Australia [28]. The isothiocyanate $(1 R, 6 S, 7 S, 10 S)-10$-isothiocyanato-4-amorphene (Ca16) $\left([\alpha]_{D}=+100^{\circ}\left(\mathrm{CCl}_{4}, \mathrm{c}=5.5\right)\right)$, the enantiomer of $\mathrm{Ca} 3\left([\alpha]_{\mathrm{D}}=-63^{\circ}\left(\mathrm{CCl}_{4}, \mathrm{c}=7.4\right)\right)$, was isolated from 
the sponges Axinella fenestratus, Topsentia sp. and Acanthella cavernosa [49]. Mitome et al. reported the isolation of $\left(1 R^{*}, 6 R^{*}, 7 S^{*}, 10 S^{*}\right)$-10-isothiocyanatocadin-4-ene (Ca17) from the Okinawan marine sponge Stylissa sp. [50]. Axinisothiocyanate K (Ca18) was isolated by Zubia et al. from a sponge of the genus Axinyssa, collected in the Gulf of California in 2008 [51]. $\left(1 R^{*}, 4 S^{*}, 6 R^{*}, 7 S^{*}\right)-4$-Isothiocyanato-9-amorphene (Ca19) was obtained from the Fijian sponge Axinyssa fenestratus and the Thailand sponges Topsentia sp. and Acanthella cavernosa [49].<smiles>CC1=CCC2=C(C1)C(C(C)C)CCC2C</smiles>

Ca1

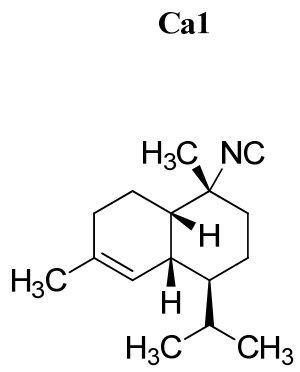

Ca12<smiles>[R]C1(C)CC[C@H](C(C)C)[C@H]2C=C(C)CC[C@H]21</smiles><smiles>[R][C@]12CC[C@@H](C)[C@@]3(C=C(C)CC[C@H]3C(C)C)[C@@H]1C2</smiles>

Ca2 $\mathrm{R}=\mathrm{NC}$

Ca3 R $=$ NCS

Ca4 R = NHCHO

Ca5 R $=$ NC

Ca6 R $=$ NCS

Ca7 R = NHCHO<smiles>[R]C1(C)CC[C@H](C(C)C)[C@H]2C=C(C)CC[C@H]21</smiles>

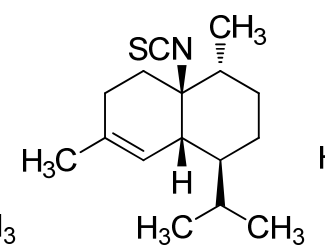

Ca13 R $=$ NC Ca14 R $=$ NCS

\section{Ca15}<smiles>CC1=CCC(C(C)C)[C@H]2C[C@](C)([N+]#N)CC[C@@H]12</smiles>

Ca20<smiles>[R]C1(C)CC=C2C(C)CC[C@H](C(C)C)[C@H]2C1</smiles>

Ca8 $\mathrm{R}=\mathrm{NC}$

Ca9 $\mathrm{R}=\mathrm{NCS}$

Ca10 R = NHCHO<smiles>CC1=CC[C@@H](C(C)C)[C@H]2CC(C)(N)CC[C@H]12</smiles>

Ca11<smiles>CC1=C[C@H]2C(C(C)C)CCC(C)([N+]#[S-])[C@@H]2CC1</smiles>

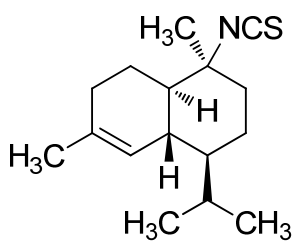

Ca16

Ca17<smiles>CC(C)C1CCC(C)(C)C2CCC(C)(O)C=C12</smiles>

Ca22<smiles>CC(C)C1CCC(C)([N+](=O)[O-])[C@@H]2C1=CC(C)(O)CCC2C</smiles>

Ca23<smiles>CC(C)C1=C2C(C(C)C)CCC(C)(O)[C@H]2CCC1(C)[N+](=O)[O-]</smiles>

Ca24

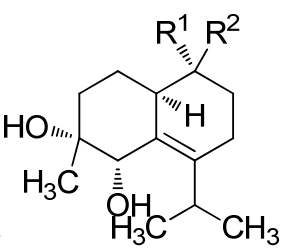

Ca25 $\mathrm{R}^{1}=\mathrm{Me}$ $\mathrm{R}^{2}=\mathrm{NCS}$

$\mathbf{C a 2 6}^{1}=\mathrm{NCS}$ $\mathrm{R}^{2}=\mathrm{Me}$

$$
\mathrm{R}^{2}=\mathrm{Me}
$$<smiles>CC(C)[C@H]1CCC(C)([N+]=[Si])[C@@]2(C)CC[C@](C)(O)C=C12</smiles>

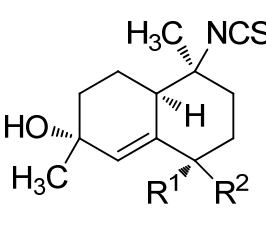

Ca30

$$
\begin{aligned}
\text { Ca31 } \mathrm{R}^{1} & ={ }^{i} \mathrm{Pr} \\
\mathrm{R}^{2} & =\mathrm{OOH} \\
\text { Ca32 } \mathrm{R}^{1} & =\mathrm{OOH} \\
\mathrm{R}^{2} & ={ }^{i} \mathrm{Pr}
\end{aligned}
$$

Ca21<smiles>CC(C)C1(O)CCC(C)(N=S)C2=CC(C)(O)CCC21</smiles>

Ca27<smiles></smiles>

Ca28 $\mathrm{R}^{1}=\mathrm{R}^{3}=\mathrm{Me}$ $\mathrm{R}^{2}=\mathrm{OH}, \mathrm{R}^{4}=\mathrm{NCS}$

Ca29 $\mathrm{R}^{1}=\mathrm{OH}, \mathrm{R}^{3}=\mathrm{NCS}$

$$
R^{2}=R^{4}=M e
$$

Figure 6. Cadinanes. 
He et al. isolated in 1989 the unusual and first marine thiocyanate Ca20 [52]. The relative stereochemistry of $\left(1 S^{*}, 4 S^{*}, 6 S^{*}, 7 R^{*}\right)$-4-thiocyanato-9-cadinene (Ca20) was determined by X-ray analysis [52]. The biogenetic relation of the thiocyanates to the classical isonitriloids remains unclear.

As for the eudesmanes (see Section 2.1.2), several hydroxylated and hydroperoxide-funtionalized cadinane sesquiterpenoids are known. The first isolated hydroxylated cadinane-type sesquiterpenoid was $\left(1 S^{*}, 4 S^{*}, 7 R^{*}, 10 S^{*}\right)$-10-isocyano-5-cadinen-4-ol (Ca21), isolated from the nudibranch Phyllidia pustulosa [53] while the closely related 10-isothiocyanatoamorph-5-en-4-ol (Ca22) was obtained from the sponges Axinella fenestratus, Topsentia sp. and Acanthella cavernosa [49]. $\left(1 S^{*}, 4 S^{*}, 7 R^{*}, 10 S^{*}\right)$-10-Isocyano-5-cadinen-4-ol (Ca21) showed antifouling activity against larvae of the barnacle Balanus amphitrite $\left(\mathrm{EC}_{50}=0.17 \mu \mathrm{g} / \mathrm{mL}\right)$ [53].

In 2008, Zubia et al. investigated specimens of the marine sponge Axinyssa sp. and were able to isolate as many as twelve new cadinane-type sesquiterpenoids, the axinisothiocyanates A-L [51]. For the non-oxygenated axinisothiocyanate K (Ca18), vide supra. Axinisothiocyanate J (Ca23) carries a hydroxy group at C-4. In contrast, axinisothiocyanates A (Ca24), B (Ca25) and C (Ca26) have two hydroxy groups at C-4 and C-5 and differ in their relative configuration. The same applies to axinisothiocyanate D (Ca27), axinisothiocyanate E (Ca28) and axinisothiocyanate F (Ca29) with the hydroxy groups at C-4 and C-7.

Another dihydroxylated isonitriloid, this time oxygenated at C-4 and at C-1, is axinisothiocyanate $G$ (Ca30). Furthermore, two isothiocyanates with one hydroxy group at $C-4$ and one hydroperoxy group at C-1, axinisothiocyanates $\mathrm{H}$ (Ca31) and I (Ca32) were isolated from the same source. The last member of the series, axinisothiocyanate L (Ca33), is characterized by a keto group at C-3.

Axiplyn C (Ca34) was isolated from the sponge Axinyssa aplysinoides, collected at Misali Island, Tanzania [54].

\subsubsection{Spiroaxane}

Di Blasio et al. isolated in 1976 the first spiroaxane-type isonitrile $(+)$-axisonitrile-3 $(\mathrm{Sp} 2)\left([\alpha]_{\mathrm{D}}\right.$ $=+68.4^{\circ}\left(\mathrm{CHCl}_{3}, \mathrm{c}=1\right)$ along with $(+)$-axisothiocyanate-3 $(\mathrm{Sp} 3)\left([\alpha]_{\mathrm{D}}=+165.2^{\circ}\left(\mathrm{CHCl}_{3}, \mathrm{c}=1\right)\right)$ and $(-)$-axamide- $3(\mathrm{Sp} 4)\left([\alpha]_{\mathrm{D}}=-6.86^{\circ}\left(\mathrm{CHCl}_{3}, \mathrm{c}=1\right)\right)$ from the marine sponge Axinella cannabina (Figure 7) [55]. Their relative configuration was determined by $\mathrm{X}$-ray crystallography while their absolute stereochemistry was determined by total synthesis of the enantiomeric (-)-axisontrile-3 (Sp6), the absolute configuration of which proved to be $(5 S, 6 R, 7 S, 10 R)$ [56]. The three compounds were also isolated from other sponges like Acanthella acuta [57], Acanthella cavernosa[19] and the nudibranchs Phyllidia ocellata [19] and Phyllidia pustulosa [42], (+)-axisonitrile-3 (Sp2) exhibited strong antimalarial activity against Plasmodium falciparum (chloroquine-sensitive strain D6: $\mathrm{IC}_{50}=142 \mathrm{ng} / \mathrm{mL}$, chloroquine-resistant strain $\mathrm{W} 2: \mathrm{IC}_{50}=16.5 \mathrm{ng} / \mathrm{mL}$ ) without cytotoxic activity against KB-3 cells $\left(\mathrm{IC}_{50}>20 \mu \mathrm{g} / \mathrm{mL}\right.$ ). The corresponding isothiocyanate $\mathrm{Sp} 3$ is 500 -fold less active than the isonitrile Sp2 (strain D6: $\mathrm{IC}_{50}=12,340 \mathrm{ng} / \mathrm{mL}$, strain W2: $\mathrm{IC}_{50}=3,110 \mathrm{ng} / \mathrm{mL}$ ) [29].

In extracts of the sponge Acanthella cavernosa was also found one of the few known marine isocyanates, axisocyanate-3 (Sp5) [58]. The enantiomeric (-)-axisonitrile-3 (Sp6) $\left(\alpha_{\mathrm{D}}^{26}=-79^{\circ}\left(\mathrm{CHCl}_{3}\right.\right.$, $\mathrm{c}=1.93))$ and $(+)$-axamide $(\mathrm{Sp} 7)\left(\alpha_{\mathrm{D}}^{26}=+17.5^{\circ}\left(\mathrm{CHCl}_{3}, \mathrm{c}=3.05\right)\right)$ were obtained from the sponge Halichondria sp., collected off Phi Phi Island in the Andaman Sea, Southern Thailand [59].

10-epi-Axisonitrile-3 (Sp8), a C-10 epimer of axisonitrile-3 (Sp6), has been isolated from the nudibranch Phyllidia pustulosa [42]. Both isonitriles exhibited potent antifouling activity against larvae of the acorn barnacle Balanus amphitrite (Sp6: $\mathrm{IC}_{50}=3.2 \mu \mathrm{g} / \mathrm{mL}, \mathbf{S p 8}$ : $\mathrm{IC}_{50}=10 \mu \mathrm{g} / \mathrm{mL}$ ) [42]. Together with the known isonitrile Sp8, exiguamide (Sp9), exicarbamate (Sp10) and exigurin (Sp11) were isolated from the sponge Geodia exigua [60]. 3-Oxoaxisonitrile-3 (Sp12) was obtained from an unidentified Chinese marine sponge of the genus Acanthella [61]. 


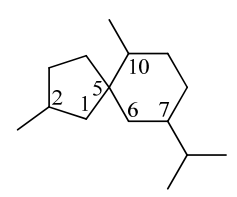

Sp1<smiles>[R]C1[C@H](C(C)C)CC[C@@H](C)[C@]12C=C(C)CC2</smiles>

Sp2 R $=$ NC Sp3 R $=$ NCS Sp4 R $=$ NHCHO Sp5 R $=$ NCO<smiles></smiles><smiles>[R]C1[C@H](C)CC[C@@]12C=C(C(C)C)CC[C@H]2C</smiles>
Sp13 R $=$ NC
Sp14 R $=$ NCS<smiles>CC(C)C1=CC2(CC(C)(NC(=O)NCCc3ccccc3)C2)C(C)CC1</smiles><smiles>[R]C1[C@H](C(C)C)CC[C@H](C)C12C=C(C)CC2</smiles>

Sp6 R $=$ NC Sp7 R $=$ NHCHO

Sp9 $\mathrm{R}=\mathrm{NHCHO}$

Sp10 R $=$ NHCOOMe

Sp11 R $=\mathrm{NHCOCH}_{2} \mathrm{~N}\left(\mathrm{CH}_{3}\right) \mathrm{CH}_{2} \mathrm{COOCH}_{3}$

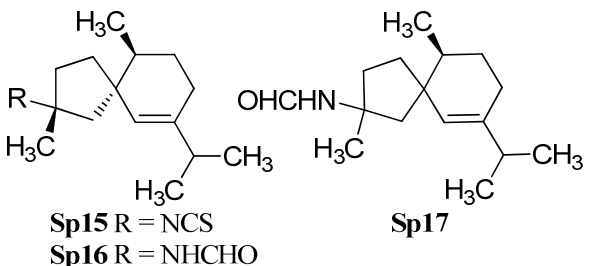

Sp19

$2 S, 5 R, 10 S$

or

Figure 7. Spiroaxanes.

In contrast to the above-mentioned spiroaxanes Sp2-Sp12, the isonitrile Sp13 and the isothiocyanate Sp14 both carry the nitrogenous functional group at C-1. Both spiroaxanes were isolated from the marine sponge Acanthella acuta [62].

$(2 R, 5 R, 10 S)$-2-Isothiocyanato-6-axene (Sp15) and (2R,5R,10S)-2-formamido-6-axene (Sp16) with the functional group at $\mathrm{C}-2$ were isolated by $\mathrm{He}$ et al. from the Palauan sponge Trachyopsis aplysinoides [52]. However, they identified the relative configuration of the both compounds as $(2 R, 5 R, 10 R)$ with a stereochemistry at C-10 unusual for natural products. Wegerski et al. revised the configuration from $(2 R, 5 R, 10 R)$ - to $(2 R, 5 R, 10 S)$-2-isothiocyanato-6-axene (Sp15) and $(2 R, 5 R, 10 S)$-2-formamido-6-axene (Sp16) [63]. During their investigations, the group also found the isothiocyanate Sp17 with $(2 S, 5 R, 10 S)$ - or $(2 R, 5 S, 10 S)$-configuration [63]. Furthermore they found in analogy to halichonadin J (Eu30), vide supra the compounds $N$-phenethyl-2-formamido-6-axene (Sp18) with either $(2 S, 5 S, 10 S)$ or $(2 R, 5 R, 10 S)$ configuration and $N$-phenethyl-2-formamido-6-axene (Sp19) with either $(2 S, 5 R, 10 S)$ or $(2 R, 5 S, 10 S)$ configuration [63].

\subsubsection{Aromadendranes}

Another type of sesquiterpene isonitriles is based on the aromadendrane-skeleton (Ar1) (Figure 8). The first example of this class was isolated directly in the early days of the discovery of marine isonitriles shortly after axisonitrile-1 (Ax2). It was found in the Mediterranean sponge Axinella cannabina collected in the bay of Taranto, Italy by Fattorusso et al. in 1974 and was named axisonitrile-2 (Ar2) [4,5]. Its relative stereochemistry was elucidated by Ciminiello twelve years later [25]. Together with axisonitrile-2 (Ar2), Fattorusso et al. were also able to isolate the corresponding formamide axamide-2 (Ar3) and the isothiocyanate congener axisothiocyanate-2 (Ar4) from the same source[5]. Axisonitrile-2 (Ar2) was later also found by Hirota in the sponge Acanthella cavernosa [47]. In 1985 Tada reported the isolation of the isothiocyanate epipolasin B (Ar4) $\left([\alpha]_{\mathrm{D}}=+91.2\left(\mathrm{CHCl}_{3}, \mathrm{c}=1.0\right)\right)$ and its $\beta$-phenylethylamine adduct epipolasinthiourea-B (Ar5) in extracts of Epipolasis kushimotoensis [64]. Epipolasin B has the same 2D-structure as axisothiocyanate-2 
(Ar4), however, based on differences in the optical rotation compared to Fattorusso's compound Ar4 $\left([\alpha]_{D}=+12.8\left(\mathrm{CHCl}_{3}, \mathrm{c}=1.5\right)\right)$, Tada proposed that both substances differ in stereochemistry. Chemical synthesis of both isothiocyanate enantiomers by da Silva makes a contamination of Fattorusso's compound likely which may have caused a wrong optical rotation and suggests both isolated substances to be in fact identical [65]. Epipolasinthiourea-B (Ar5) showed moderate cytotoxic activities against the murine $\mathrm{L} 1210$ leukemia cell line $\left(\mathrm{ED}_{50}=3.7 \mu \mathrm{g} / \mathrm{mL}\right)$ [64].

Examination of Acanthella cannabina collected off the coast of Taranto near Porto Cesareo (Italy) by Ciminiello et al. in 1987 resulted in the isolation of $10 \alpha$-isocyanoalloaromadendrane (Ar6), 10 $\alpha$-formamidoalloaromadendrane (Ar7) and 10 $\alpha$-isothiocyanatoalloaromadendrane (Ar8), an isonitriloid triad showing a C1-epimeric alloaromadendrane-skeleton compared to Ar2, Ar3 and Ar4 [25].

An isothiocyanate with an opposite stereochemistry with the exception of C-10, $(1 R, 4 S, 5 S, 6 R, 7 S, 10 R)-(+)$-isothiocyanatoalloaromadendrane (Ar9), was found in 1996 by Hirota et al. in an Acanthella cavernosa from Hachijo-jima Island (Japan) [20]. The absolute configuration was elucidated by comparison with the corresponding alcohols synthesized from (-)-alloaromadendrene. The compound was isolated again in 2010 by Lyakhova et al. from the Vietnamese nudibranch Phylidiella pustulosa [27]. The enantiomer Ar10 of this compound was prepared synthetically in 1994 by da Silva et al. and allowed the determination of the absolute configuration [65]. Ar9 and axisothiocyanate-2 (Ar4) were found to display potent antifouling activity against cyprid larvae of the acorn barnacle Balanus amphitrite [20].

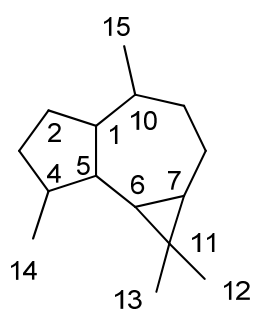

Ar1

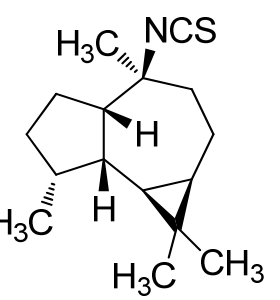

Ar10<smiles>[R][C@]1(C)CC[C@@H]2[C@@H]([C@H]1C)C2(C)C</smiles>

Ar2 $\mathrm{R}=\mathrm{NC}$

Ar3 $\mathrm{R}=\mathrm{NHCHO}$

Ar4 R $=$ NCS Ar5 R $=\mathrm{NHCSNHCH}_{2} \mathrm{CH}_{2}-\mathrm{Ph}$

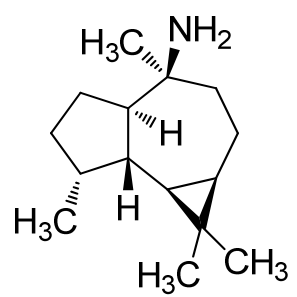

Ar11<smiles></smiles>

Ar6 $\mathrm{R}=\mathrm{NC}$

Ar7 R $=$ NHCHO

$\operatorname{Ar8} \mathrm{R}=\mathrm{NCS}$<smiles>[R][C@]12CC[C@@H](C)[C@H]1[C@H]1[C@H](C)CC[C@H]1C2(C)C</smiles>

$\operatorname{Ar12} \mathrm{R}=\mathrm{NCS}$

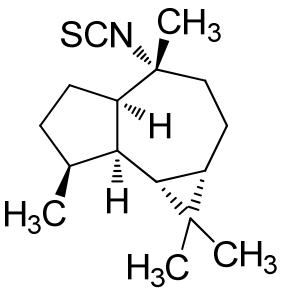

Ar9<smiles>[R][C@]12CC[C@@H](C)[C@]1([2H])[C@H]1[C@H](C)CC[C@H]1C2(C)C</smiles>

$\operatorname{Ar13} \mathrm{R}=\mathrm{NC}$

$\operatorname{Ar14} \mathrm{R}=\mathrm{NCS}$

$\operatorname{Ar15} \mathrm{R}=\mathrm{NCO}$

$\operatorname{Ar16} \mathrm{R}=\mathrm{NHCHO}$

Figure 8. Aromadendranes.

Investigation of a Halichondria sp. collected near Unten Port (Okinawa, Japan) by Ishiyama et al. in 2008 led to the isolation of halochonadin F (Ar11), an amine epimeric at C-1 to da Silva's compound. It was found to exhibit antimicrobial activity against Micrococcus luteus (MIC $=4 \mu \mathrm{g} / \mathrm{mL}$ ), Trichophyton mentagrophytes (MIC $8 \mu \mathrm{g} / \mathrm{mL}$ ) and Cryptococcus neoformans (MIC $16 \mu \mathrm{g} / \mathrm{mL}$ ) [66].

In 1988, Breakman reported the isolation of an isonitrile, an isothiocyanate, and an isocyanate from the sponge Acanthella acuta (Banyuls, France) bearing the nitrogen functionality at C-1 instead 
of C-10 of the aromadendrane skeleton. Due to a misassigned reference substance, a wrong relative configuration was initially published [9,57], which was corrected two years later [67]. The first two compounds were found in parallel in an Acanthella acuta sponge collected in the Bay of Naples (Italy) by Mayol who elucidated the correct relative stereochemistry of Ar13 and Ar14 [62].

The formamide Ar16 was discovered in 2007 by Zhang et al. in the Spanish dancer nudibranch Hexabrandies sanguinens collected in the South China Sea [68]. The isolation of the corresponding isocyanate Ar15 was reported in 2007 by Jumaryatno from an Australian specimen of Acanthella cavernosa (Coral gardens, Gneerings reef, Mooloolaba) [32]. In 1992, He and Faulkner were able to identify the C1/C10-epimer Ar12 of isothiocyanate Ar14 in a sponge Axinyssa aplysinoides collected at Ant Atoll (Pohnpei/Micronesia) [69].

\subsubsection{Epimaalianes}

The epimaaliane sesquiterpenoids have a similar skeleton to the eudesmanes with a methyl group in C-4 and C-10 position but they possess an additional bond between C- 6 and C-11, creating a cyclopropane ring (Ep1, Figure 9).

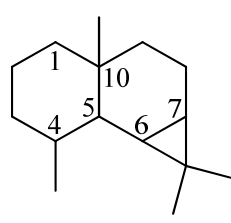

Ep1<smiles>[R][C@]1(C)CCC[C@]2(C)[C@H]3[C@@H](CC[C@H]12)C3(C)C</smiles>

$$
\begin{aligned}
& \text { Ep2 R }=\text { NC } \\
& \text { Ep3 R }=\text { NCS } \\
& \text { Ep4 R }=\text { NHCHO }
\end{aligned}
$$

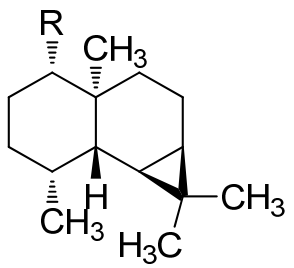

Ep7 $\mathrm{R}=\mathrm{NC}$

Ep8 R $=$ NCS

Ep9 $\mathrm{R}=\mathrm{NHCHO}$

Figure 9. Epimaalianes.

The first isolated epimaaliane-type sesquiterpenoids were the unnamed isonitrile Ep2 and (-)-epipolasin A (Ep3) $\left([\alpha]_{D}=-12^{\circ}\left(\mathrm{CHCl}_{3}, \mathrm{c}=1.1\right)\right)$ isolated from the nudibranch Cadlina luteomarginata by Thompson et al. in 1982 [70]. Their relative stereochemistry was determined by X-ray crystallography of the formamide Ep4 which was obtained by hydrolysis of the isonitrile Ep2 [70]. Later, (-)-epipolasin A (Ep3) was isolated from the sponges Acanthella pulcherrima [28] and Axinyssa sp. nov. [71] and along with the isonitrile Ep2 and the formamide Ep4 from a Northeastern Pacific Acanthella sp. [23]. The isonitrile Ep2 and the formamide Ep4 were also isolated from skin extracts of the nudibranch Cadlina luteomarginata while the corresponding (-)-epipolasin A was not found in this organism [23]. (+)-Epipolasin A (Ep5) $\left([\alpha]_{D}=+7.6^{\circ}\left(\mathrm{CHCl}_{3}, \mathrm{c}=1\right)\right)$ was found in the sponge Epipolasis kushimotoensis by Tada and Yasuda [64]. The absolute stereochemistry was deduced by correlation of ECD-spectra with those of the naturally occurring maaliol. The related isonitrile and formamide were not found while the thiourea compound Ep6 was isolated from the same producer [64]. (+)-Epipolasin A (Ep5) shows activity against Plasmodium falciparum strains D6 $\left(\mathrm{IC}_{50}=5600 \mathrm{ng} / \mathrm{mL}\right)$ and $\mathrm{W} 2\left(\mathrm{IC}_{50}=5550 \mathrm{ng} / \mathrm{mL}\right)$ whithout exhibiting cytotoxic activity against $\mathrm{KB}$ cells $\left(\mathrm{IC}_{50}>20 \mu \mathrm{g} / \mathrm{mL}\right)$ [71].

The isonitrile Ep7, the isothiocyanate Ep8 and the formamide Ep9 with the functional group attached to C-1 instead of C-4 were found during further investigations of extracts of the sponge Axinella cannabina by Ciminiello et al. [72].

\subsubsection{Pupukeananes}

A further group of sesquiterpenoids are the pupukeananes which bear a tricyclo[4.3.1.0 3,7 decane skeleton (Pu1, Figure 10). The first isolated pupukeanane was 9-isocyanopupukeanane (Pu2) which was obtained from the nudibranch Phyllidia varicosa and an unidentified sponge of the 
genus Hymeniacidon by Burreson et al. in 1975 [73]. Later, Hymeniacidon sp. was reclassified as a Ciocalypta sp. [74]. The corresponding C-9 epimer 9-epi-isocyanopupukeanane (Pu3) was isolated from the nudibranch Phyllidia bourguini along with 9-isocyanopupukeanane (Pu2) [75]. Later, the corresponding 9-isothiocyanatopupukeanane (Pu4) was found in the sponge Axinyssa sp. nov., collected at the Great Barrier Reef, Australia [71]. 9-Isocyanopupukeanane (Pu2) displayed a weak antimalarial activity against Plasmodium falciparum (strain D6: $\mathrm{IC}_{50}=2520 \mathrm{ng} / \mathrm{mL}$, strain W2 $\left.\mathrm{IC}_{50}=1610\right)$ and showed no activity against $\mathrm{KB}$ cells $\left(\mathrm{IC}_{50}>20 \mu \mathrm{g} / \mathrm{mL}\right)$. In contrast to isonitrile Sp2 and isothiocyanatate Sp3, the antimalarial activity of the corresponding isothiocyanate $\mathbf{P u} 4$ was similar to isonitrile Pu2 (strain D6: $\mathrm{IC}_{50}=3290 \mathrm{ng} / \mathrm{mL}$, strain W2: $\mathrm{IC}_{50}=890 \mathrm{ng} / \mathrm{mL}$ ) [71].

Remarkably and in sharp contrast to the other sesquiterpenoid subgroups, numerous thiocyanates with a pupukeanane skeleton are known. 9-Thiocyanatopupukeanane (Pu5) and its C-9 epimer 9-epi-thiocyanatopupukeanane (Pu6) were isolated from the nudibranch Phyllidia varicosa and the sponge Axinyssa aculeata, collected from the coral reefs of Pramuka Island, Indonesia [76]. Both compounds Pu5 $\left(\mathrm{IC}_{50}=4.6 \mu \mathrm{g} / \mathrm{mL}\right)$ and Pu6 $\left(\mathrm{IC}_{50}=2.3 \mu \mathrm{g} / \mathrm{mL}\right)$ showed potent antifouling activity against larvae of the acorn barnacle Balanus amphitrite [42].

In addition to the C-9 functionalized pupukeananes, some C-2 and C-5 functionalized representatives of this class ar known as well. 2-Isocyanopupukeanane (Pu7) was obtained by Hagadone et al. from the nudibranch Phyllidia varicosa together with isonitrile Pu2 [77]. He et al. isolated the corresponding 2-thiocyanatopupukeanane (Pu8) from the sponge Axinyssa aplysinoides [69]. Recently the corresponding formamide Pu9 was isolated from Phyllidia coelestis Bergh, collected near the Koh-Ha Islets, Thailand [78].

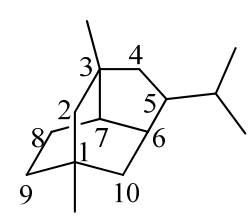

Pu1<smiles>[R]C1([R])CC2C(C(C)C)CC3(C)CC2C1C3</smiles>

Pu2 $\mathrm{R}^{1}=\mathrm{NC}, \mathrm{R}^{2}=\mathrm{H}$

Pu3 $\mathrm{R}^{1}=\mathrm{H}, \mathrm{R}^{2}=\mathrm{NC}$

Pu4 $\mathrm{R}^{1}=\mathrm{NCS}, \mathrm{R}^{2}=\mathrm{H}$

Pu5 $\mathrm{R}^{1}=\mathrm{SCN}, \mathrm{R}^{2}=\mathrm{H}$

Pu6 $\mathrm{R}^{1}=\mathrm{H}, \mathrm{R}^{2}=\mathrm{SCN}$<smiles>[R]C1C2CC3(C)CC2C(C(C)C)CC1(C)C3</smiles>

Pu7 R = NC

Pu8 $\mathrm{R}=\mathrm{SCN}$

Pu9 R = NHCHO<smiles>CC(C)C1([N+](=O)[O-])CC2CCC1(C)CC2(C)C</smiles>

Pu10

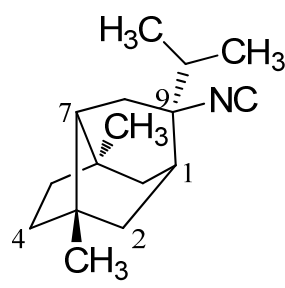

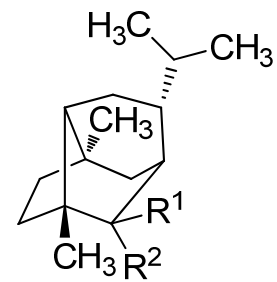<smiles>CC(C)[C@@H]1C2CC3CC(C)(C2)CC3(C#N)C1(C)C</smiles>

Pu11

Pu12 $\mathrm{R}^{1}=\mathrm{H}, \mathrm{R}^{2}=\mathrm{SCN}$

Pu13

Pu12a $\mathrm{R}^{1}=\mathrm{SCN}, \mathrm{R}^{2}=\mathrm{H}$<smiles>CN[C@]1(C)CC2CC1C1CCC2(C)C[C@@H]1C(C)C</smiles>

Pu14

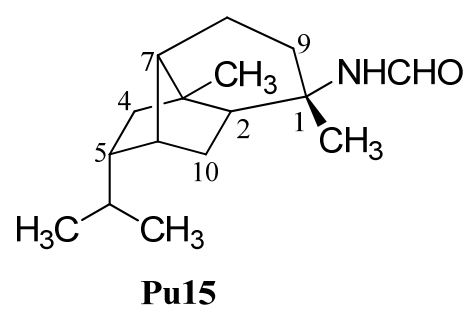

Pu15

Figure 10. Pupukeananes. 
Furthermore, one pupukeanane with an isothiocyanate group at C-5 (Pu10) was obtained by Marcus et al. from a sponge of the genus Axinyssa [43].

In addition, there are some rearranged pupukeananes like 9-isocyanoneopupukeanane (Pu11), which was obtained from the sponge Ciocalypta sp. collected in O'ahu, Hawaii [79]. 2-Thiocyanatoneopupukeanane (Pu12) was first isolated at 1991 by Pham et al. from an unidentified Phonpei sponge but they determined the configuration of the functional group at C-2 incorrectly (Pu12a) [80]. One year later He et al. also isolated the thiocyanato compound Pu12 from the sponge Axinyssa aplysinoides and revised the configuration at C-2 on the basis of NMR experiments [69]. 2-Thiocyanatoneopupukeanane (Pu12) showed a similar antimalarial activity against Plasmodium falciparum (strain D6: $\mathrm{IC}_{50}=4700 \mathrm{ng} / \mathrm{mL}$, strain W2: $\mathrm{IC}_{50}=890 \mathrm{ng} / \mathrm{mL}$ ) as 9-isocyanopupukeanane (Pu2) and 9-isothiocyanatopupukeanane (Pu4) [71]. 4-Thiocyanatoneopupukeanane (Pu13) was also isolated by Pham et al. from the sponge Phycopsis terpnis [80].

Apart from the pupukeananes (Pu2-Pu10) and the neopupukeananes (Pu11-Pu13), two other rearranged pupukeananes are known: 2-Isocyanoallopupukeanane (Pu14) was obtained from the nudibranch Phyllidia pustulosa by Fusetani et al. [47] and Jaisamut et al. isolated 1-formamido-10 $(1 \rightarrow 2)$-abeopupukeanane (Pu15) from the nudibranch Phyllidia coelestis Bergh [78].

\subsubsection{Bisabolanes}

Bisabolane-type compounds have a 1-methyl-4-(6-methyl-2-heptanyl)cyclohexane skeleton (Bi1) and the functional group is either located at C-3 or at C-7 (Figure 11). The first isolated bisabolane compounds were 3-isothiocyanatotheonellin (Bi3) and 3-formamidotheonellin (Bi4) from the Okinawan sponge Theonella cf. swinhoei reported by Nakamura et al. in 1984 [81]. The analog 3-isocyanotheonellin (Bi2) was isolated two years later by Gulavita et al. from the nudibranch Phyllidia sp. [74]. 3-Isocyanotheonellin (Bi2) showed potent antifouling activity against larvae of the acorn barnacle Balanus amphitrite $\left(\mathrm{IC}_{50}=0.13 \mu \mathrm{g} / \mathrm{mL}\right)$ [42]. In 2012 Wright et al. reported the isolation and characterization of 3-isocyanatotheonellin (Bi5) together with the known isonitrile Bi2, isothiocyanate Bi3 and 7-isothiocyanato-7,8-dihydro- $\alpha$-bisabolene (Bi7) from the sponge Raphoxya sp., collected near Blue Hole, Guam [82].<smiles>CC(C)CCCC(C)C1CCC(C)CC1</smiles>

Bi1<smiles>[R]C1(C)CCC(/C(C)=C/C=C/C(C)C)CC1</smiles>

Bi3 R $=$ NCS

Bi4 $\mathrm{R}=\mathrm{NHCHO}$

Bi5 R = NCO

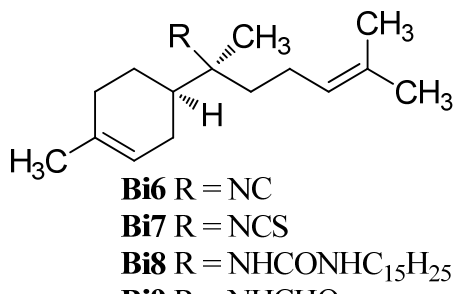

Bi9 $\mathrm{R}=\mathrm{NHCHO}$<smiles>[R]C(C)(CCC=C(C)C)[C@H]1CC=C(C)CC1</smiles><smiles>C=C(CCC=C(C)C)[C]1CCC(C)(C)CC1</smiles>

Bi12<smiles>CC(C)=CC/C=C(\C)C1CCC(C)(C)CC1</smiles>

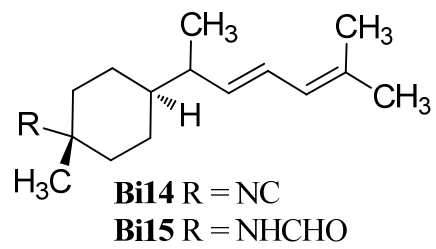<smiles>CC(C)=CCCC(C)(C#N)C1CC=C(C)CC1</smiles>

Figure 11. Bisabolanes. 
The latter compound was also found in the sponge Halichondria sp. together with the urea derivate $N, N^{\prime}$-bis $((6 R, 7 S)-7,8$-dihydro- $\alpha$-bisabolen-7-yl)urea (Bi8) in 1986 [83]. The related 7-isocyano7,8-dihydro- $\alpha$-bisabolene (Bi6) was isolated from the tropical marine sponge Acanthella cavernosa by Jumaryatno et al. in 2007 [32] and 7-formamido-7,8-dihydro- $\alpha$-bisabolene (Bi9) was isolated from the Hainan marine sponge Axinyssa sp. by Li et al. in 2008 [84].

In 1986, Gulavita et al. also reported the isolation of 7-isocyano-7,8-dihydro- $\alpha$-bisabolene (Bi10), the C-7 epimer of the isonitrile Bi6, and 7-isocyanato-7,8-dihydro- $\alpha$-bisabolene (Bi11) from the sponge Ciocalypta sp. [74].

The isonitrile Bi12 with an exo-methylene group at C-7 was obtained from the nudibranch Phyllidiella pustulosa from the South China Sea [35]. (E)-4-Isocyanobisabolane-7,10-diene (Bi13) with two non-conjugated double bonds was isolated from an Okinawan sponge of the genus Axinyssa [85].

Kassuehlke et al. reported the isolation of 3-isocyanobisabolane-8,10-diene (Bi14) from the nudibranch Phyllidia pustulosa and the appropriate 3-formamidobisabolene-8,10-diene (Bi15) from the Paulauan sponge Halichondria cf. lendenfeldi. However, the full characterization of the formamide Bi15 was not possible due to decomposition [86].

The thiocyanate axinythiocyanate A (Bi16) was obtained from the sponge Axinyssa isabela, collected in the Gulf of California, Mexico [33].

In the past 15 years, a considerable number of oxygenated bisabolanes were isolated and characterize, the majority of which being oxygenated formamides (Figure 12).

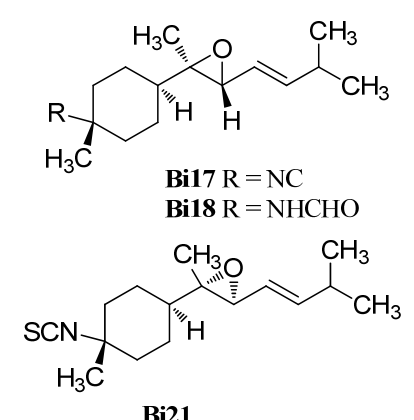

Bi21<smiles>CCOC(C)(C)/C=C/C=C(\C)C1CCC(C)(NC=O)CC1</smiles>

Bi24<smiles>C=NC1(C)CCC(C(C)=CC2OC2(C)C)CC1</smiles><smiles>C/C(=C\C=C\C(C)C)C1CCC(C)(NC(=O)C(C)(C)OC(C)(C)C)CC1</smiles><smiles>C=C(/C(O)=C/C(C)C)C1CCC(C)(NC=O)CC1</smiles>

Bi22<smiles>CCOC(C)(/C=C/C=C(C)C)C1CCC(C)(NC=O)CC1</smiles>

Bi25<smiles>C=C(C(=O)/C=C/C(C)C)C1CCC(C)(NC=O)CC1</smiles>

Bi23<smiles>CC(/C=C/C(O)C(C)(C)O)C1CCC(C)(NC=O)CC1</smiles>

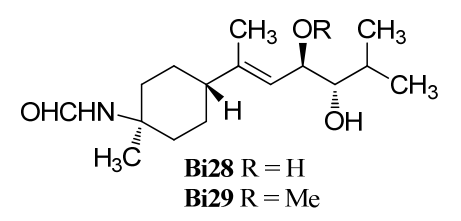<smiles>C/C(=C\C(O)C1OC1(C)C)C1CCC(C)(NC=O)CC1</smiles>

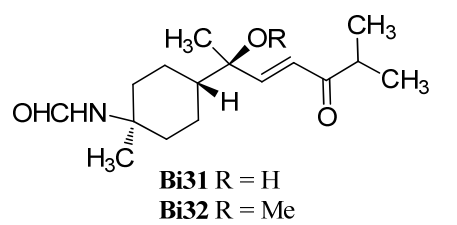

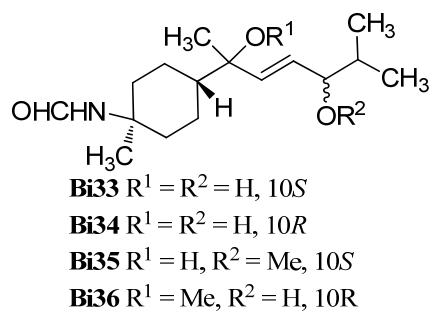

Figure 12. Oxygenated bisabolanes. 
Sun et al. reported the isolation of 3-isocyano-7,8-epoxy- $\alpha$-bisabolane (Bi17) and the corresponding 3-formamido-7,8-epoxy- $\alpha$-bisabolane (Bi18) from the Hainan sponge Axinyssa sp. [87]. Recently, axinysaline A (Bi20) and axinysaline B (Bi19) were found in an unidentified Formosan sponge of the genus Axinyssa by Liu et al. [88].

Previously, the only oxygenated isothiocyanato compound was $7 \alpha, 8 \alpha$-epoxy theonellin isothiocyanate (Bi21) which was isolated from Phycopsis sp. collected from the Mandapam coast in the Gulf of Mannar, Tamilnadu, India [89].

The first reported oxygenated bisabolanes were 3-formamidobisabolane-14(7),9-dien-8-ol (Bi22), 3-formamidobisabolane-14(7),9-dien-8-one (Bi23) and 3-formamido-8-methoxybisabolan-9-en-10-ol (Bi36). They were all isolated from a Micronesian sponge of the genus Axinyssa along with the known 3-formamidotheonellin (Bi3) [90].

Two uncommon bisabolanes with an ethoxy group at C-7 or C-11 respectively, 11-ethoxy-3formamidotheonellin (Bi24) and 7-ethoxy-3-formamidobisabolane-8,10-diene (Bi25), were isolated from a Hainan sponge Axinyssa aff. variabilis by Mao et al. [91].

In 2014, Cheng et al. reported the isolation of ten oxygenated formamidobisabolanes (Bi26-Bi35) from a Chinese sponge (Axinyssa sp.) [92]. Axinyssine C (Bi26) has two hydroxy groups at C-10 and $\mathrm{C}-11$ and a double bond in 8-position. Axinyssine D (Bi27) has the same structure as Bi26 but bears a methoxy group at $\mathrm{C}-10$. Axinyssines $\mathrm{E}$ and $\mathrm{F}$ (Bi28 and $\mathbf{B i 2 9}$ ) have the same functional groups as Bi26/Bi27 but the double bond is located at C-7, one hydroxy group is found at C-10 and the other hydroxy/methoxy group is attached to C-9. However, axinyssine G (Bi30) has one hydroxy group at $\mathrm{C}-9$ and an epoxy group at C-10. NOE experiments revealed a $7 E$ geometry and the coupling constant $J_{H-9 / H-10}=8.0 \mathrm{~Hz}$ suggests a threo-orientation of the two stereocenters in the side chain. The absolute configuration of C-9 was determined by ECD spectra of the $\mathrm{Rh}_{2}\left(\mathrm{OCOCF}_{3}\right)_{4}$ complex. Axinyssine $\mathrm{H}$ (Bi31) has a hydroxy group at C-7 and a keto group at C-10. Axinyssine I (Bi32) is the methoxylated analogue of Axinyssine $\mathrm{H}$ (Bi31). The compounds Bi33-Bi36 are the reduced compounds of axinyssine $\mathrm{H}$ (Bi31) and axinyssine I (Bi32). Axinyssine J (Bi33) has two hydroxy groups and the hydroxy-group-bearing $\mathrm{C}-10$ has $S$-configuration. In contrast, axinyssine $\mathrm{K}$ (Bi34) has $R$-configuration at C-10. Axinyssine L (Bi35) carries a methoxy group at C-7 and a hydroxy group at the $S$-configured 10-position. The corresponding 3-formamido-8-methoxybisabolan-9-en-10-ol (Bi36) was isolated earlier [90].

\subsubsection{Guaianes}

Guaiane-type sesquiterpenoids have a similar skeleton to the aromadendranes but are devoid of the cyclopropane ring (Gu1, Figure 13). Tada et al. reported the first isolation of guaiane isonitriloids in 1988. The isonitrile $\mathbf{G u 2}$, the isothiocyanate $\mathbf{G u} 3$ and the formamide $\mathbf{G u} 4$ were obtained from an unidentified sponge [93]. However, the authors speculated that the formamide $\mathrm{Gu} 4$ was not produced by the sponge but rather was an isolation artifact originating from hydrolysis of Gu2 during column chromatography [93]. The isothiocyanate $\mathrm{Gu} 3$ was also isolated from the tropical marine sponge Acanthella cavernosa wich was followed by a more detailed characterization but the orientation of the isothiocyanato group could not be elucidated [32]. Tada et al. deduced the relative configuration of the other congeners based on X-ray crystallography of the isonitrile Gu2 [93]. 


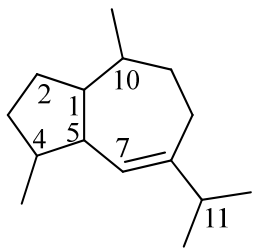

Gu1<smiles>[R]C1(C)CCC(C(C)C)=C[C@H]2[C@@H](C)CC[C@H]21</smiles>

Gu2 R = NC

Gu3 R $=$ NCS

Gu4 R = NHCHO<smiles>[R]C1(C)CCC(C(C)C)=C[C@H]2[C@@H](C)CC[C@H]21</smiles>

Gu5 R $=$ NCS

Gu6 R $=\mathrm{NC}$<smiles>[R]C1CCC(C)=C[C@H]2[C@@H](C(C)C)CC[C@]12C</smiles>

Gu7 $\mathrm{R}=\mathrm{NC}$

Gu8 R = NCS<smiles>[R]CC1=C[C@H]2[C@@H](C(C)C)CC[C@]2(C)CCC1</smiles>

Gu9 $\mathrm{R}=\mathrm{NC}$

Gu10 R = NCS

Figure 13. Guaianes.

$\left(1 S^{*}, 4 S^{*}, 5 R^{*}, 10 S^{*}\right)$-10-Isothiocyanatoguaia-6-ene (Gu5) was isolated from the sponge Trachyopsis aplysinoides collected in Palau [52]. The corresponding isonitrile Gu6 was isolated in 2004 from the nudibranch Pthyllidiella pustulosa from the South Chinese Sea [35].

In 2008, Li et al. reported the isolation of 4,5-epi-10-isothiocyanatoisodauc-6-ene (Gu8) from the Hainan marine sponge Axinyssa sp. [84]. In contrast to the other guaianes (Gu2-Gu6), one of its methyl groups is not located at C-10 but at C-1 and the isopropyl group and the methyl group at C-8 and C-4 are interchanged. The corresponding isonitrile $(\mathbf{G u} 7)$ was obtained recently by Wright $e t$ al. from the nudibranch Phyllidia ocellata [94].

Another unusual isonitrile/isothiocyanate pair, Gu9/Gu10, was isolated in 1987 by Mayol et al. from the sponge Acanthella acuta [62]. Similar to the isonitrile Gu7 and the isothiocyanate Gu8, the methyl group is located at C-1 and the isopropyl group and the methyl group are interchanged but the nitrogenous functional group is attached to the exocyclic allylic carbon.

\subsubsection{Other Sesquiterpenoids}

Apart from the above-mentioned subclasses, there is a small number of marine isonitriloids with uncommon sesquiterpene-based skeletons (Figure 14). He et al. reported in 1989 the isolation of 2-isothiocyanatotrachyopsane (Fu2) with a novel "trachyopsane" skeleton, which is related to the pupukeanane skeleton, from the sponge Trachyopsis aplysinoides [52]. The corresponding 2-isocyanotrachyopsane (Fu1) was obtained seven years later by Okino et al. from four nudibranchs of the Phyllidiidae family [42]. 2-Isocyanotrachyopsane (Fu1, $\mathrm{IC}_{50}=0.33 \mu \mathrm{g} / \mathrm{mL}$ ) exhibited potent antifouling activity against larvae of the acorn barnacle Balanus amphitrite [42]. 2-(Formylamino) trachyopsane (Fu3) and $N$-phenethyl- $N^{\prime}$-2-trachyopsane (Fu4) were isolated from the Palauan sponge Axinyssa aplysinoides [95].

The gorgonane skeleton is very similar to the eudesmane skeleton but the isopropyl group is located at C-6 instead of at C-7. Kassuehlke et al. reported the isolation of $4 \alpha$-isocyanogorgon-11-ene (Fu5) and $4 \alpha$-formamidogorgon-11-ene (Fu7) from the Philippine nudibranch Phyllidia varicosa along with $4 \alpha$-isothiocyanatogorgon-11-ene (Fu6) found in the nudibranch Phyllidia pustulosa [86].

Recently, White et al. isolated (-)-(1S,2R,5R,8R)-1-isothiocyanatoepicaryolane (Fu8), the first compound with a caryolane skeleton containing a nitrogenous functional group, from the nudibranch Phyllidia ocellata [94]. 
<smiles>[R]C1(C)CC2CC1CC(C(C)C)C2C</smiles>

Fu1 $\mathrm{R}=\mathrm{NC}$

Fu2 R $=$ NCS

Fu3 $\mathrm{R}=\mathrm{NHCHO}$

Fu4 $\mathrm{R}=\mathrm{NHCONHCH}_{2} \mathrm{CH}_{2} \mathrm{Ph}$<smiles>[R]C1(C)CCC[C@@]2(C)[C@H](C(=C)C)CCC[C@H]12</smiles>

Fu5 $\mathrm{R}=\mathrm{NC}$

Fu6 $\mathrm{R}=\mathrm{NCS}$

Fu7 R $=$ NHCHO

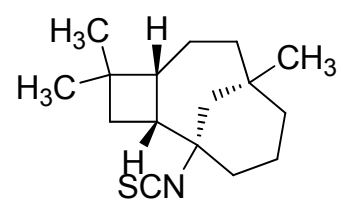

Fu8<smiles>C[C@H]1CC[C@H](C(C)(C)C)[C@H]2[C@@H](C)CC[C@@H]1[C@H]2C</smiles>

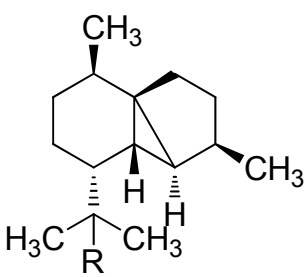

Fu10 R $=$ NC

Fu11 R = NCS

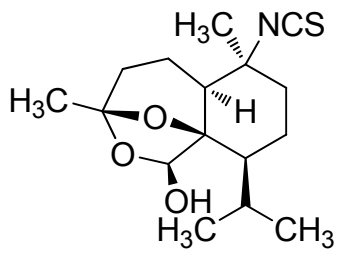

Fu14

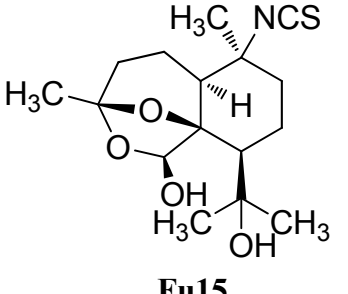

Fu15<smiles></smiles>

Fu12<smiles>CC1(C)C[C@H](C#N)[C@@]23CCC[C@@](C)(CC[C@@H]12)C3</smiles>

Fu13

Figure 14. Further sesquiterpenoids.

Cubebane sesquiterpenoids possess a very similar skeleton to the cadinanes but they have an additional bond between C-1 and C-5. The first cubebane type sesquiterpenoid, $\left(1 S^{*}, 2 R^{*}, 5 S^{*}, 6 S^{*}, 7 R^{*}, 8 S^{*}\right)$-13-isothiocyanatocubebane (Fu9), was isolated by He et al. from the sponge Axinyssa aplysinoides [69]. The relative configuration was defined by NOEDS experiments. The C-2 epimer $\left(1 S^{*}, 2 S^{*}, 5 S^{*}, 6 S^{*}, 7 R^{*}, 8 S^{*}\right)$-13-isothiocyanatocubebane (Fu11) was isolated later by Mitome et al. from the Okinawan sponge Stylissa sp. [50]. The corresponding $\left(1 S^{*}, 2 S^{*}, 5 S^{*}, 6 S^{*}, 7 R^{*}, 8 S^{*}\right)$-13-isocyanocubebane (Fu10) was obtained in 2015 by White et al. from the nudibranch Phyllidia ocellata [94].

The same group also isolated $(-)-(1 S, 5 S, 8 R)$-2-isocyanoclovene (Fu12) and the saturated (-)-(1S,2R,5S,8R)-2-isocyanoclovane (Fu13) from the nudibranch Phyllidia ocellata [94]. The $(1 S, 5 S, 8 R)$-configuration of the isonitrile Fu12 was determined by X-ray crystallography of the corresponding formamide, which could be obtained by treatment of isonitrile Fu12 with glacial acetic acid. The new stereocenter in the isonitrile Fu13 was identified by NOESY experiments. The authors propose that the cycloclovane skeleton is formed from the epicaryolane skeleton by an 1,2-alkyl shift [94].

In 2008 Sorek et al. reported the isolation of five new marine isothiocyanates (Axiplyns A-E) from the sponge Axinyssa aplysinoides collected at Misali Island, Tanzania [54]. Axiplyn A (Fu14) and B (Fu15) contain a unprecedented ring system, 6,8-dioxabicyclo[3.2.1] octane. However, Axiplyn D (Fu16) has a bridged hydroindane skeleton and Axiplyn E (Fu17) has a 2-oxabicyclo[2.2.1]heptane core. Axiplyn C (Ca34) is a cadinane type sesquiterpenoid and was already described in Section 2.1.3. Axiplyns A $\left(\mathbf{F u 1 6}, \mathrm{LD}_{50}=1.6 \mu \mathrm{g} / \mathrm{mL}\right), \mathrm{B}\left(\mathbf{F u 1 7}, \mathrm{LD}_{50}=1.5 \mu \mathrm{g} / \mathrm{mL}\right)$ and C $\left(\mathbf{C a 3 3}, \mathrm{LD}_{50}=1.8 \mu \mathrm{g} / \mathrm{mL}\right)$ displayed toxic activities to brine shrimp larvae (Artemia salina) [54]. 


\subsection{Diterpenoids}

Beside the cyclic sesquiterpenoid compounds already presented in this review, a large fraction of marine isonitriles and isothiocyanates were found to have diterpenoid backbones. They can be categorized into three classes: Acyclic diterpenes, kalihinanes, and amphilectanes.

Until today, six acylic compounds, 69 kalihinanes and 50 amphilectanes have been isolated.

\subsubsection{Acyclic}

The smallest class, the acyclic diterpenoids, is represented by a isonitriloid triad consisting of isocyanate Acy1, isothiocyanate Acy2 and formamide Acy3, which were the only representatives found until 2006 (Figure 15). The triad was found in 1974 by Burreson et al. along with cyclic sesquiterpenes in an unidentified Halichondria species [39,40].<smiles>[R]C(C)(C=C)CCC=C(C)CCC=C(C)CCC=C(C)C</smiles>

$\operatorname{Acy} 1 \mathrm{R}=\mathrm{NC}$

Acy2 $\mathrm{R}=\mathrm{NCS}$

$\operatorname{Acy} 3 \mathrm{R}=\mathrm{NHCHO}$

Figure 15. Acyclic diterpenoids.

Further open-chain terpenoid formamides were isolated from sea fans. Malonganenone C (Acy4), a diterpenoid formamide showing moderate cytotoxic activity against esophageal cancer cell lines, was found in extracts of the gorgonian Leptogorgia gilchristi collected near Ponto Malongane, Mozambique by Keyzers in 2006 (Figure 16) [96]. It was also found in another sea fan, Euplexaura nuttingi (Uvinage, Pemba Island, Tanzania) in 2007 by Sorek et al. who were able to isolate Malonganenone $C$ along with its $\Delta^{11,12}-(E)$ double bond isomer malonganenone $\mathrm{H}$ (Acy5) [97]. Examination of Euplexaura robusta collected near Weizhou Island (Guangxi Province, China) in 2012 by Zhang et al. revealed the $\Delta^{10,11}$-double bond isomer Malonganenone K (Acy6) [98]. Despite the occurrence of these three new members this class of acyclic compounds still appears as an exception among the other diterpenoid isonitriles which are usually cyclic.

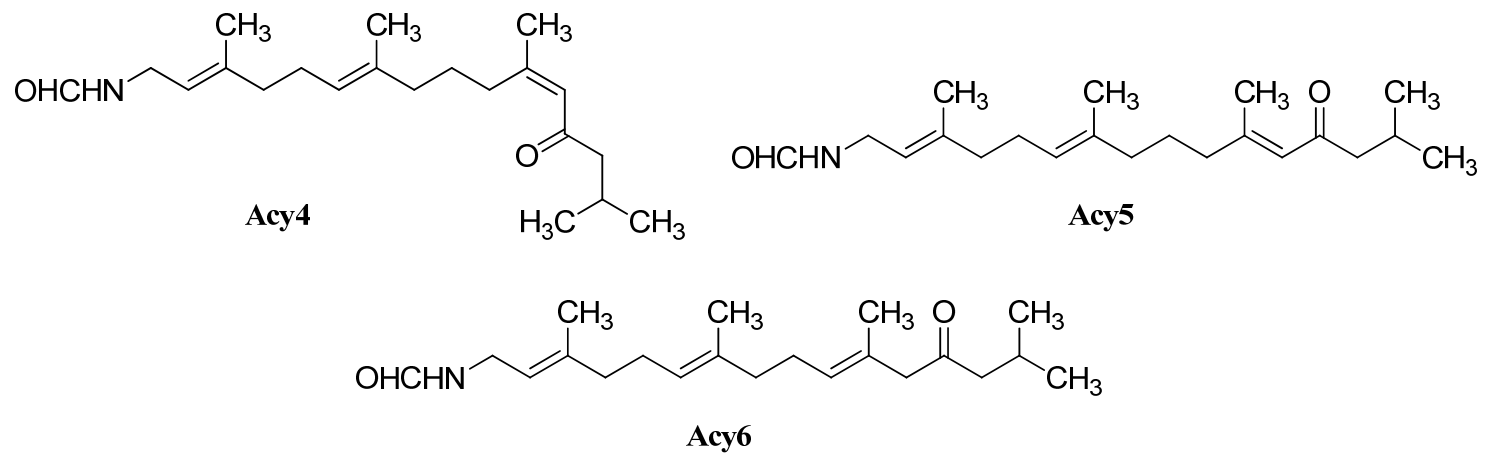

Figure 16. Malonganenones. 


\subsubsection{Kalihinanes}

Common to all kalihinanes is the decalin ring system which, apart from some exceptions (cavernenes) which will be discussed later on, either bears a tetrahydofuran, a tetrahydropyran or a dihydropyran moiety linked to C-7. All three rings can bear a large variety of functional groups including isocyano-, isothiocyanato- and hydroxy groups or chlorine. The kalihinanes can be further classified into kalihinols, kalihinenes, kalihipyranes and cavernenes. Most kalihinanes were found in A. cavernosa whereas also a few examples exist that were isolated from the sponge Phakellia pulcherrima.

\section{Kalihinols}

Characteristic for the kalihinols is the tertiary alcohol function at C-4 of a trans-decalin system being part of a bifloran skeleton (Figure 17). They can be further subdevided into two groups according to their substitution with a tetrahydropyran or a tetrahydrofuran moiety at C-7. The first eleven kalihinols were found by the Scheuer group of Hawaii in 1987 in two sponges of Acanthella sp. (later indentified as A. cavernosa) [99] and were published in a series of communications [100-102]. The kalihinols A-H were isolated from an Acanthella sp. collected at Guam, whereas examination of a Fijian Acanthella species revealed kalihinols X (Kol4), Y (Kol9) and Z (Kol3). Kalihinols A (Kol1), $\mathrm{E}$ (Kol6), X (Kol4), Y (Kol9) and Z (Kol3) are all linked at C-7 to a C-14 chlorinated tetrahydropyran moiety and bear an isonitrile function at C-5. Kalihinol E (Kol6) represents the C-14-epimer of kalihinol A (Kol1) just having another orientation of the chlorine substituent. The formamide derivatives of A and E, 10 $\beta$-formamido kalihinol A (Kol2) and 10ß-formamido kalihinol E (Kol7) were isolated in 1996 by Hirota et al. from A. cavernosa while the isothiocyanato derivative, found in the same producer by Xu et al. in 2004, was named kalihinol O (Kol8) [20]. Kalihinol Z (Kol3) on the other hand represents the C-10-epimer of kalihinol A (Kol1), whereas kalihinol X (Kol4) is the 10-isothiocyanato derivative of kalihinol Z (Kol3). Further investigation of A. cavernosa by Sun et al. in 2009 revealed a kalihinol with the opposite stereochemistry at C-10, 10-epi-kalihinol X (Kol5) [103]. Unlike the other tetrahydropyran kalihinols, kalihinol Y (Kol9) bears an exocyclic methylene group at C-10. In 1998, Wolf was able to isolate along with kalihinol Y its double bond isomer $\Delta^{9}$-kalihinol Y (Kol10) from the sponge Phakellia pulcherrima, which was the first time that kalihinanes were found in sponge other than A. cavernosa [104]. Independently from Wolf, Miyaoka also discovered the same kalihinol in A. cavernosa in the same year [105]. In antihelmintic screenings, kalihinol Y (Kol9) displayed extremely high activity against the rodent-pathogenic roundworm Nippostongylus brasiliensis. The kalihinols A (Kol2), X (Kol4) and Z (Kol3) also showed high activity [106].

The first time that kalihinols with other functional groups than the isonitrile group at C-5 were found in 1991 when Alvi was able to isolate kalihinols I (Kol14) and J (Kol13) from A. cavernosa, which are the 5-formamide and the 5-isothiocyanato congeners of kalihinol X (Kol4) respectively [49]. 10-epi-Kalihinol I (Kol15) was isolated by Miyaoka, while Hirota et al. were able to identify the C-5 isocyanato- and isothiocyanato-derivatives $10 \beta$-formamido- $5 \beta$-isothiocyanato-kalihinol A (Kol16) and $10 \beta$-formamido-5 $\beta$-isocyanato-kalihinol A (Kol17) [20,105]. The isocyanato derivative of kalihinol A (Kol1) was found in 2012 by Xu et al. and was named kalihinol P (Kol11) as well as kalihinol $\mathrm{S}$ (Kol12), representing the C-5 formamide derivative of 10-epi-kalihinol X (Kol5) [107]. Further investigations of the same sample revealed kalihinols Q (Kol18) and R (Kol19), which are the C-14 epimers of Kol11 and Kol15 respectively [107]. 


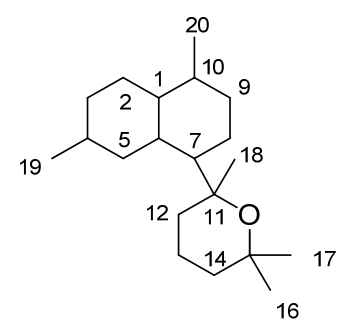

Kol

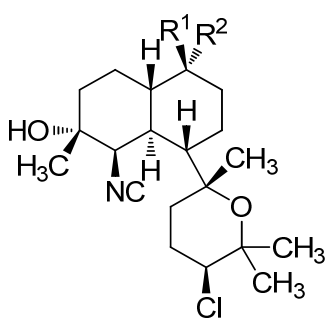

$\mathbf{R}^{1}$

$\mathbf{R}^{2}$

Kol1 NC Me A

Kol2 NHCHO Me $10 \beta$-form. A

Kol3 Me NC Z

Kol4 Me NCS X

Kol5 NCS Me 10-epi-X

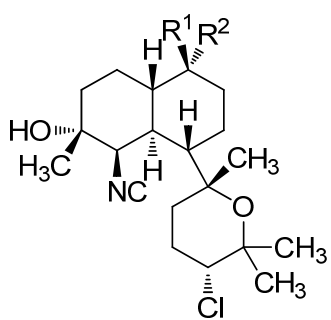

$R^{1} \quad R^{2}$

Kol6 NC Me E

Kol7 NHCHO Me $10 \beta$-form. E

Kol8 NCS Me O

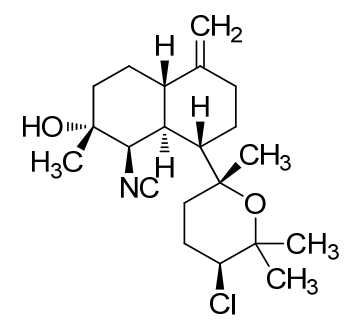

Kol9 Y

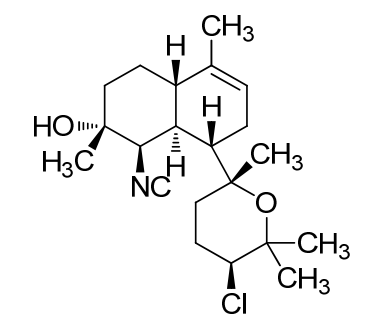

Kol10 $\Delta^{9}-$ Y

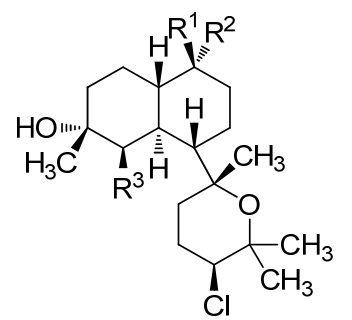

$\mathbf{R}^{1}$

Kol11 NC Kol12 NCS

Kol13 Me

Kol14 Me

Kol15 NCS

Kol16 NHCHO Me

NHCHO Me NCO

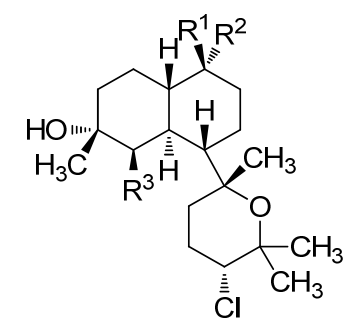

$\begin{array}{lll}\mathbf{R}^{1} & \mathbf{R}^{2} & \mathbf{R}^{3}\end{array}$

Kol18 NC Me NCS Q

Kol19 NCS Me NCS R

Figure 17. Tetrahydropyran kalihinols.

The first representatives of the tetrahydrofuran subclass of kalihinols were kalihinols B (Kol20), C (Kol28), D (Kol30), F (Kol21), G (Kol24) and H (Kol26) discovered by the Scheuer group in the 1980s (Figure 18) [101,102]. The stereochemical and functional variations occur at C-5 and C-10 as in the tetrahydropyran-type kalihinols. Additionally, the tetrahydrofuran moiety can be functionalized at C-15 with isonitrile, isothiocyanate, formamide or chlorine. Examples bearing an isopropenyl side chain are also known.

Kalihinol F (Kol21), a representative of the tetrahydrofuran-type kalihinols, is substituted with three isonitrile groups at C-5, C-10 and C-15. It was shown to be a topoisomerase I inhibitor in Asterina pectinifera, inhibiting the chromosome separation in fertilized starfish eggs [108] and to have antimicrobial activity against Bacillus subtilis, Staphylococcus aureus and Candida albicans [101]. Kalihinol B (Kol20) differs from Kalihinol F (Kol21) just in the functional group at C-15, which is a chlorine instead of an isocyano group. In 2004, Bugni was able to isolate the formamide derivatives 10-formamido kalihinol F (Kol22) and 15-formamido kalihinol F (Kol23) from two Philippine specimens of $A$. cavernosa [109]. The C-15 isothiocyanate derivative of kalihinols B and $\mathrm{F}$ was named kalihinol G (Kol24), while kalihinol H (Kol26) represents the C-10-isothiocyanato derivative of kalihinol F [102]. 

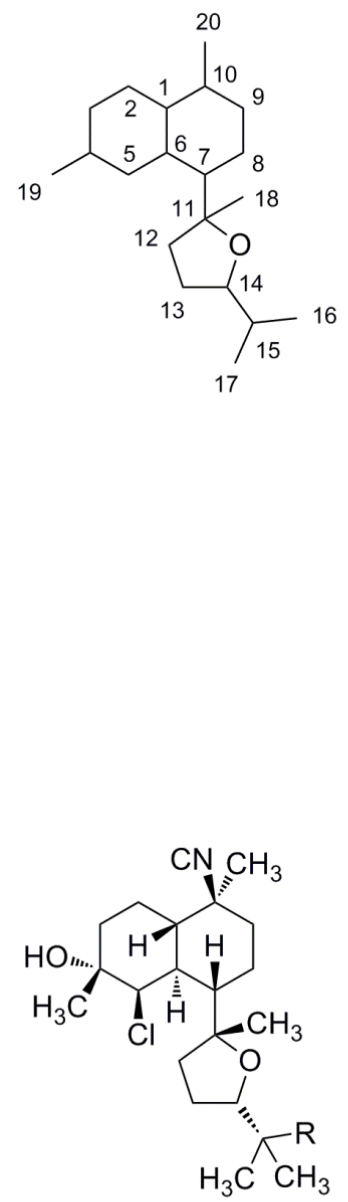

$\begin{array}{ll}\text { Kol30 R }=\text { NC } & D \\ \text { Kol31 R }=\text { NCS } & T\end{array}$

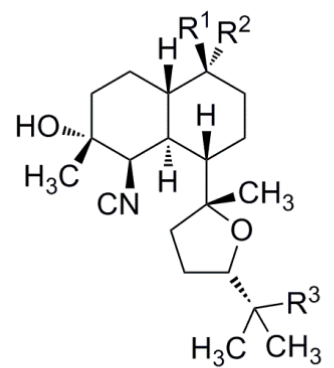

\begin{tabular}{llll}
\multicolumn{1}{c}{$\mathbf{R}^{\mathbf{1}}$} & $\mathbf{R}^{\mathbf{2}}$ & $\mathbf{R}^{\mathbf{3}}$ & \\
Kol20 NC & Me & Cl & B \\
Kol21 NC & Me & NC & F \\
Kol22 HNCHO & Me & NC & 10 -form. F \\
Kol23 NC & Me & NHCHO 15 -form. F \\
Kol24 NC & Me & NCS & G \\
Kol25 NCS & Me & NCS & 10 -isothio. G \\
Kol26 NCS & Me & NC & H \\
Kol27 Me & NCS & NC & 10 -epi H
\end{tabular}

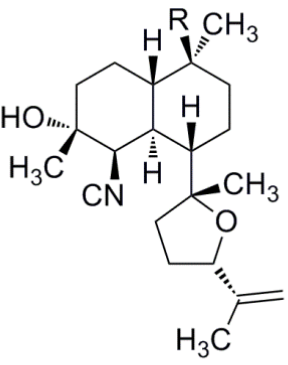

Kol28 R $=$ NC $\quad \mathrm{C}$

Kol29 R = NCS 10-isothio. C

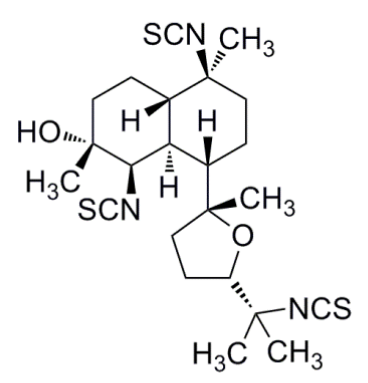

Kol34 5,10-bisisothio. G

Figure 18. Tetrahydrofuran-substituted kalihinols.

The first member of the class bearing an isopropenyl side chain was kalihinol C (Kol28), which is functionalized at C-5 and C-10 with two isonitrile groups. Kalihinol D (Kol30) represents the 5-Cl-derivative of kalihinol F (Kol21)[102]. Its C-15-isothiocyanato derivative, kalihinol T (Kol31), was isolated by $\mathrm{Xu}$ in 2012 from A. cavernosa [107].

In 1998, the Miyaoka group was able to isolate the tris-isothiocyanato compound 5,10-bisisothiocyanatokalihinol G (Kol34) [105]. Further tetrahydrofuran-type kalihinols were presented in the same year by Wolf et al. who identified 10-isothiocyanato kalihinol G (Kol25), 10-epi-kalihinol H (Kol27), and 10-isothiocyanato kalihinol C (Kol29) from a sample of Phakellia pulcherrima [104]. From the same sample, the structures of two compounds with a 10-exo-methylene group were elucidated, kalihinol K (Kol32) bearing an isonitrile substituent at C-5 and its isothiocyanato derivative kalihinol L (Kol33), representing the tetrahydrofuran analogues of kalihinol Y (Kol9) [104].

Already in 1988, Omar et al. were able to isolate a variant of the kalihinols with swapped positions of the hydroxy and isonitrile groups at C-4 and C-5 (Figure 19) [106]. The stereochemistry of both groups is opposite compared to the normal kalihinols, presumably due to a different opening of the intermediate epoxide in the biosynthetic pathway. The first example of this so-called "isokalihinols" was isokalihinol F (Kol36) which, except for C-4 and C-5, showed the same configuration and functionalization as kalihinol F (Kol21). 8-OH-Isokalihinol F (Kol41), a rather unusual isokalihinol bearing an additional hydroxy group at C-8, was isolated by Clark et al. in 2000 from A. cavernosa collected at Heron Island (Great Barrier Reef, Australia) [31]. 


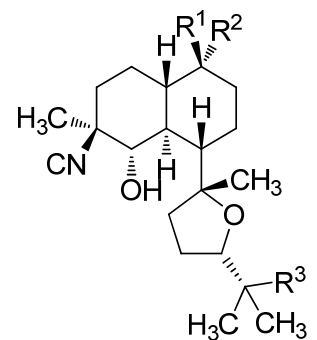

$\begin{array}{lll}\mathbf{R}^{1} & \mathbf{R}^{2} & \mathbf{R}^{3}\end{array}$

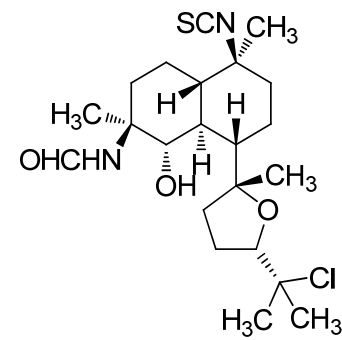

Kol39 M

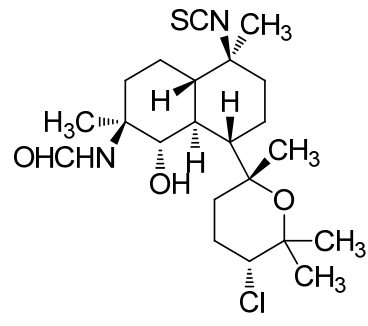

Kol40 N

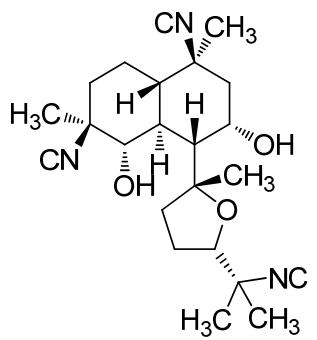

Kol41 8-OH-Isokalihinol F

Figure 19. Isokalihinols.

Three further isokalihinols with an NC-function at C-4 are known to date: Isokalihinol B (Kol35), being related to kalihinol B (Kol20), was found in 1990 by Fusetani in a marine sponge collected in Kuchihoerabu Island of the Satsunan Archipelago (Japan) which was identified as Acanthella klethra [110]. Rodriguez and Crews revised this assignment afterwards based on voucher samples to be actually A. cavernosa [99]. Isokalihinol B (Kol35) and kalihinene (Ken1) demonstrated besides antifungal activities against Mortierella romannicus and Penicillium chrysogenum also cytotoxic potency against P388 murine leukemia cells ( $\mathrm{IC}_{50}=0.8 \mu \mathrm{g} / \mathrm{mL}$ and $1.2 \mu \mathrm{g} / \mathrm{mL}$ ), respectively [110].

Many kalihinanes displayed antifouling potency. Kalihinols Kol1 $\left(\mathrm{EC}_{50}=0.087 \mu \mathrm{g} / \mathrm{mL}\right), \mathbf{K o l 2}$ $\left(\mathrm{EC}_{50}<0.5 \mu \mathrm{g} / \mathrm{mL}\right), \mathrm{Kol6}\left(\mathrm{EC}_{50}<0.5 \mu \mathrm{g} / \mathrm{mL}\right), K_{017}\left(\mathrm{EC}_{50}=0.5 \mu \mathrm{g} / \mathrm{mL}\right), K_{0116}\left(\mathrm{EC}_{50}=0.05 \mu \mathrm{g} / \mathrm{mL}\right)$ and Kol17 $\left(\mathrm{EC}_{50}=0.05 \mu \mathrm{g} / \mathrm{mL}\right)$ and kalihinenes Ken2 $\left(\mathrm{EC}_{50}=0.095 \mu \mathrm{g} / \mathrm{mL}\right), \operatorname{Ken} 14\left(\mathrm{EC}_{50}=0.49 \mu \mathrm{g} / \mathrm{mL}\right)$, $\operatorname{Ken} 15\left(E_{50}=0.45 \mu \mathrm{g} / \mathrm{mL}\right)$ and $\operatorname{Ken} 16\left(\mathrm{EC}_{50}=1.1 \mu \mathrm{g} / \mathrm{mL}\right)$ were shown to inhibit the attachment and metamorphosis of cyprid larvae of the acorn barnacle Balanus amphitrite [20,111].

The other two known isokalihinols are 10-epi-isokalihinol F (Kol37) and the C-4,5-regioisomer of 10-epi-kalihinol H (Kol27), 10-epi-isokalihinol H (Kol38), which were isolated by Faulkner in 1994 from A. cavernosa collected in the Seychelles [112].

In 2012, Xu et al. reported two novel C-4 formamido representatives of isokalihinols in a South China Sea specimen of A. cavernosa, kalihinol M (Kol39) bearing an isothiocyanato group at C-10 and a chlorine atom at C-15 and kalihinol N (Kol40), the 4-formamido-iso-derivative of kalihinol O (Kol8), representing the first example of isokalihinols of the tetrahydropyran type [107].

\section{Kalihinenes}

Common to all kalihinenes is the trisubstituted $\Delta^{4}$-double bond and a heterocyclic $\mathrm{C}_{8}$-substituent at C-7 equal to the kalihinols. However, unlike the kalihinols, which to date exclusively featured trans-decalin skeletons, the kalihinenes also exist with cis-decalin backbones (Figure 20).

The prototype of this class after which all other members are named, kalihinene (Ken1), was found in 1990 by Fusetani in a misassigned Acanthella klethra sample (actually cavernosa) [110]. Examination of a Fijian sample of $A$. cavernosa by Rodriguez et al. resulted in the isolation and identification of 15-formamido-kalihinene (Ken2), 10-formamido kalihinene (Ken3) and 10,15-bisformamido kalihinene (Ken4) [99]. The team additionally proved the persistence of these compounds in sponges kept in an aquaculture for seven months. Together with the three cis-formamido kalihinenes, Rodriguez et al. were also able to identify four members with a novel 6-hydroxy kalihinene framework. The first representative, 6-hydroxy-kalihinene (Ken5), exhibits the same cis-decalin backbone and functional groups as kalihinene but is hydroxylated at C-6. The other isolated examples are the formamido- and formamido-isothiocyanato derivatives 6-hydroxy-15-formamido kalihinene 
(Ken6), 6-hydroxy-10-formamidokalihinene (Ken7) and 6-hydroxy-10-formamido-15-isothiocyanato kalihinene (Ken8) [99].

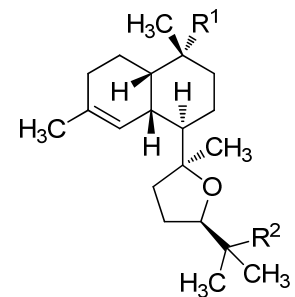

\begin{tabular}{lll}
\multicolumn{1}{c}{$\mathbf{R}^{\mathbf{1}}$} & $\mathbf{R}^{\mathbf{2}}$ & \\
Ken1 NC & NC & kalihinene \\
Ken2 NC & NHCHO & 15-form.-kalihinene \\
Ken3 NHCHO & NC & 10-form.-kalihinene \\
Ken4 NHCHO & NHCHO & 10,15-bisform.-kalihinene
\end{tabular}

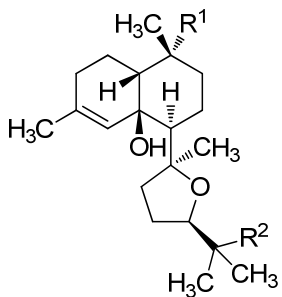

$\begin{array}{rlr}\mathbf{R}^{1} & \mathbf{R}^{2} & \\ \text { Ken5 NC } & \text { NC } & \text { 6-OH-kalihinene }\end{array}$

Ken6 NC NHCHO 6-OH-15-form.-kalihinene

Ken7 NHCHO NC 6-OH-10-form.-kalihinene

Ken8 $\mathrm{NHCHO}$ NCS 6-OH-10-form.-15-isothio.-

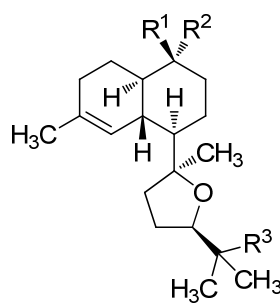<smiles>CC1=CC2(C3(C)CCC(C(C)(C)NC=O)O3)CCC(C)C2CCC1C</smiles>

$\begin{array}{lll}\mathbf{R}^{1} \quad \mathbf{R}^{2} & \mathbf{R}^{3}\end{array}$

Ken9 $\mathrm{NC}$ Me $\mathrm{NC}$ kalihinene A (diepi-kalihinene) Ken12 F

Ken10 Me NC NC kalihinene B(1-epi-kalihinene)

Ken11 Me NC NCS 15-isothio--1-epi-kalihinene

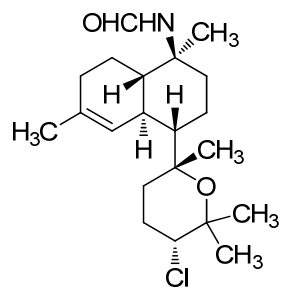

Ken13 E

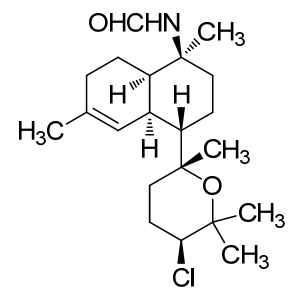

Ken14 X<smiles>CC1=C[C@@H]2C(C)(C)CC[C@@](C)(N=C=O)[C@@]2(C=O)CC1</smiles>

Ken15 Y<smiles>CC1=C[C@H]2[C@H](CC1)[C@@](C)(N=C=O)CC[C@]2(C)C1CC[C@@H](Cl)C(C)(C)O1</smiles>

Ken16 Z

Figure 20. Kalihinenes.

Another variation of the cis-decalin tetrahydrofuran-substituted kalihinenes is kalihinene $\mathrm{F}$ (Ken12), which was isolated in 2012 by Xu et al. and bears a trisubstituted $\Delta^{9}$-double bond similar to $\Delta^{9}$ kalihinol Y (Kol10) [113].

Three kalihinenes with a trans-decalin framework were reported in 1994 by Faulkner et al. [112]. Besides kalihinene A (also named diepi-kalihinene) (Ken9) which is, apart from the double bond, identical to kalihinol F (Kol21), the group could also isolate kalihinene B (or 1-epi-kalihinene) (Ken10) and 15-isothiocyanato-1-epi-kalihinene (Ken11). In contrast to the twelve isolated members of the tetrahydrofuran-substituted kalihinene series, only four tetrahydropyran derivatives are known to date. The first three examples were the kalihinenes X (Ken14), Y (Ken15), and Z (Ken16) isolated in 1995 by Okino et al. from A. cavernosa [111]. All of them bear a formamide function at C-10 and a chlorine at C-14. Differences only consist in the stereochemistry at C-1 and C-14. In 2012, the Xu group added the missing fourth diastereomer kalihinene E (Ken13) also found in the same producer [113]. Its absolute configuration was elucidated by $\mathrm{X}$-ray crystallography. 
Kalihinene (Ken1), kalihinol A (Kol1), and kalihinol E (Kol6) were also found by Manzo et al. in 2004 in Phylidiella pustulosa, a nudibranch from the South China Sea [35]. The dietary origin of these diterpenoids is strongly supported by several investigations.

Besides the tetrahydropyran and tetrahydrofuran series of kalihinenes, a third group of kalihinenes with a different pendant $\mathrm{C}_{8}$-unit exists. The first member of this class, kalihipyran (Kpy1), was discovered by Faulkner et al. in 1994 in A. cavernosa (Figure 21) [112]. It shows a kalihinene type trans-decalin system with an isonitrile function at C-10 and is connected at C-7 to a dihydropyran with isopropenyl side chain. Its C-10 formamide derivative kalihipyran A (Kpy2) was isolated in 2012 by Xu et al. along with the cis-decalin derivative kalihipyran C (Kpy4) [113]. Kalihipyran B (Kpy3) isolated by Fusetani, again features a trans-decalin backbone, but contains a chlorine in the side chain [114]. The configuration at C-14 remains unknown.

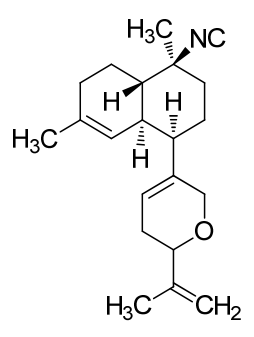

Kpy1

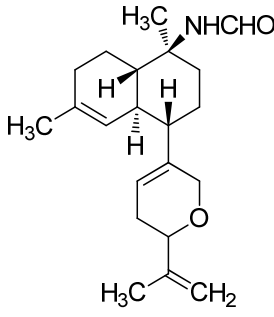

Kpy2

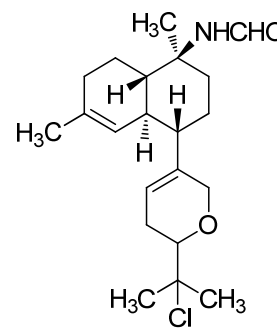

Kpy3

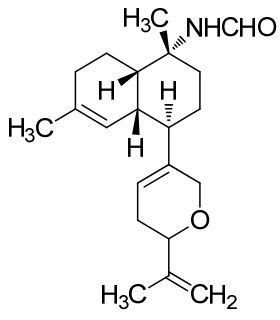

Kpy4

Figure 21. Kalihipyrans.

\section{Cavernenes and Other Intermediates}

Over the years, a couple of potential intermediates in the biosynthetic pathway of kalihinanes have been identified (Figure 22). In 1996, the first example of a new class of kalihinane diterpenes with an open-chained substituent at C-7 and a kalihinene cis-decalin framework was discovered in Cymbastella hooperi by König et al. who determined the relative configuration to correspond to that of $\left(1 S^{*}, 6 R^{*}, 7 R^{*}, 10 S^{*}, 11 R^{*}\right)$-10-isothiocyanatobiflora-1,14-diene (Int5) $\left([\alpha]_{\mathrm{D}}=+45^{\circ}\left(\mathrm{CHCl}_{3}, \mathrm{c}=0.26\right)\right)$ [115].<smiles>C=C(CCC=C(C)C)[C@H]1CC[C@H](C)[C@]2(NC=O)CCC(C)=C[C@H]12</smiles>

Int1

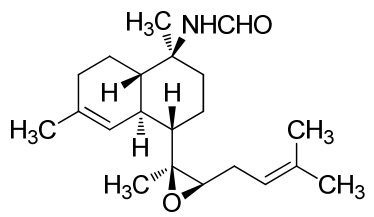

Int4<smiles>CC(C)=CCCC(C)[C@H]1CC[C@](C)(N=C=O)[C@H]2CCC(C)=C[C@@H]21</smiles>

Int2

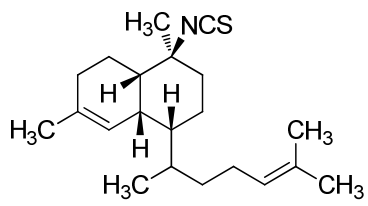

Int5<smiles>CC(C)=CCCC(C)[C@H]1CC[C@@](C)(N=C=O)[C@H]2CCC(C)=C[C@H]21</smiles>

Int3<smiles>CC(C)=CCCC(C)C1CCC(C)(C)[C@H]2CCC[C@](C)(O)[C@H]1[C@H]2N</smiles>

Int6<smiles>CC(C)=CCC1OC1(C)C1CCC(C)(N)C2(C)CCCC(C)(C)[C@H]12</smiles>

Int7

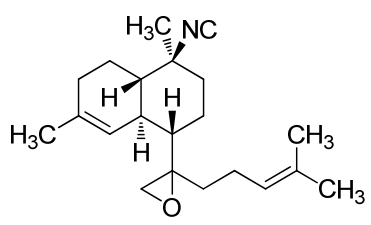

Int8

Figure 22. Intermediates. 
Already in 1992, a kalihinene derivative with an open isoprenoid side chain was isolated by Sharma et al. from a sample of Adocia sp. showing the same 2D structure but a different optical rotation $\left([\alpha]_{\mathrm{D}}=+97^{\circ}\left(\mathrm{CHCl}_{3}, \mathrm{c}=0.085\right)\right)$ compared to König's compound [116]. Its relative configuration was not elucidated.

Examination of an A. cavernosa sponge, collected at Heron Island (Great Barrier Reef, Australia) by Clark et al. in 2000 resulted in the isolation of two oxirane-derivatives, 11,12-epoxy-10-isocyano-4,14-bifloradiene (Int7) possessing a trisubstituted epoxide in the side chain and a trans-decalin framework, and 11,18-epoxy-10-isocyano-4,14-bifloradiene (Int8) featuring a terminal epoxide group. The authors suggest the latter one to be a precursor to the kalihipyran ring system [31].

From the same sponge, four further members of this class of intermediates were reported by Xu et al. in 2012, which all bear a formamide group at C-10 and differ just in the nature of the side chain linked to C-7 and the cis- or trans-configuration of the decalin moiety. Cavernene A (Int1), a trans-decalin, is connected to an isoprenoid unit. In contrast to cavernene A (Int1), cavernene B (Int2) shows a monoolefinic isoprenoid side chain, while cavernene C (Int3) is identical to cavernene B (Int2) apart from the cis-decalin moiety. Cavernene D (Int4) possesses a trisubstituted epoxide in the side chain and the same trans-decalin unit as cavernenes A and B and represents the C-10-formamido derivative of Int7 [113].

The missing link in the kalihinol synthesis was discovered by Wolf et al. in 1998 in a sample of Phylidiella pulcherrima and was named pulcherrimol (Int6) [104]. In contrast to the other intermediates, it shows the decalin framework of kalihinol A, which makes its role as an intermediate in the biosynthesis of kalihinols plausible.

For the proposed role of the intermediates in the kalihinane synthesis see the Chapter 3 on biosynthesis.

\subsubsection{Amphilectanes}

Besides the diterpenoid class of highly substituted decalins, the kalihinanes, which are found almost exclusively in A. cavernosa and apart from the small group of acyclic diterpenes, a third class of naturally occurring diterpenoid isonitriles with tricyclic or tetracyclic structures is known. These so-called amphilectanes are predominantly found in Amphimedon sp., Hymenacidon amphilecta and Halichondria sponges and can furthermore be subdivided based on their carbon frameworks into amphilectanes, cycloamphilectanes, isocycloamphilectanes, neoamphilectanes and isoneoamphilectanes (Figure 23). Recently the assignment of the species Hymeniacidon amphilecta has been revised to Pseudoaxinella amphilecta and will be referred to in the latter way hereinafter [117].

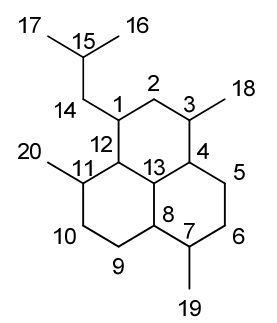

amphilectanes

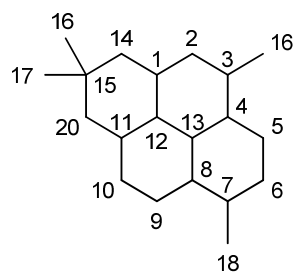

cycloamphilectanes

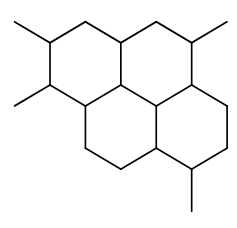

isocycloamphilectanes

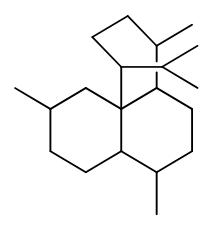

neoamphilectanes

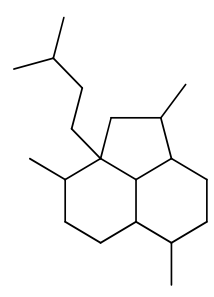

isoneoamphilectanes

Figure 23. Amphilectane frameworks.

\section{Amphilectenes}

Examination of the Caribbean sponge Pseudoaxinella amphilecta by Wratten et al. in 1978 revealed a diterpenoid diisocyanide with a novel tricyclic carbon skeleton, 8,15-diisocyano-11(20)amphilectene/((-)-DINCA) (Amp1) which became the lead substance of the new class of 
amphilectenes (Figure 24). It was shown later by Ciavatta et al. to reduce the proliferation of $\mathrm{T}$ and B lymphocytes [118]. In the same source, the goup around Wratten was also able to isolate its 15-formamide derivative Amp2 [119].<smiles>CC1=CCC2C(C)CCC3C(C)CC(CC(C)C)C(C1)C23</smiles>

Amp<smiles>CC(C)=CC1=C2[C@H](C)CC[C@]3(C)[C@H](C)CC[C@@H]([C@H]1C)[C@]23C</smiles>

Amp6<smiles>[R]C1(C)CC[C@H]2[C@@H](C)C[C@@H](C=C(C)C)[C@H]3C(=C)CC[C@@]21[C@@H]3C</smiles>

Amp13 R $=$ NC

Amp14 R $=$ NHCHO<smiles>CC(C)=C[C@@H]1C[C@@H](C)[C@H]2CC[C@](C)(C#N)[C@H]3CC=C(C)[C@H]1[C@@H]32</smiles>

Amp19<smiles>[R]C(C)(C)C[C@H]1C[C@@H](C)[C@@H]2CC[C@](C)(C#N)[C@@H]3CCC(=C)[C@H]1[C@H]23</smiles>

Amp23 R $=$ NC Amp24 R = NCS<smiles>[R]C([R])(C)C[C@H]1C[C@@H](C)[C@H]2CC[C@H](C)[C@]3(C)CCC(=C)[C@H]1[C@H]23</smiles>

Amp1 R $=$ NC Amp2 R $=$ NHCHO Amp3 R $=$ NCS<smiles>C=C(C)C[C@H]1C[C@@H](C)[C@H]2CC[C@H](C)[C@]3(C)CCC(=C)[C@@H]1[C@H]23</smiles>

Amp7<smiles>CC(C)=C[C@@H]1C[C@@H](C)[C@H]2CC[C@](C)(C#N)[C@H]3CCC(C)=C1[C@H]32</smiles>

Amp15

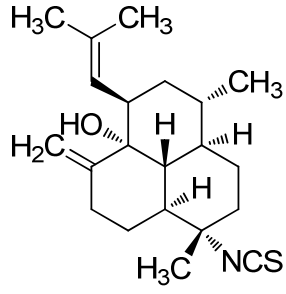

Amp20<smiles>C=C(C)C[C@H]1C[C@@H](C)[C@H]2CC[C@](C)(N)[C@H]3CCC(=C)[C@@H]1[C@H]32</smiles>

Amp25<smiles>C=C1CC[C@@]2(C)[C@@H]3[C@@H]1[C@H](C=C(C)C)C[C@@H](C)[C@H]3CC[C@H]2C</smiles>

Amp4<smiles>CC(C)=C[C@H]1C[C@@H](C)[C@H]2CC[C@@H](C)[C@]3(C)CC=C(C)[C@H]1[C@]23C</smiles>

Amp5

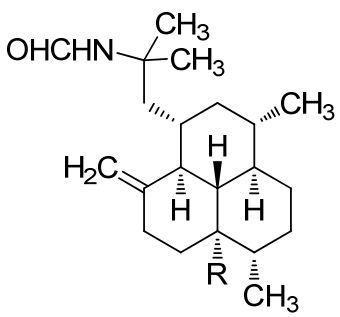

$$
\text { Amp8 R }=\text { NCO }
$$$$
\text { Amp9 R }=\text { NCS }
$$<smiles>[R]C1(C)CC[C@H]2[C@@H](C)C[C@@H](CC(=C)C)[C@H]3C(=C)CC[C@@]21[C@@H]3C</smiles>

Amp16 R $=$ NC Amp17 R $=$ NHCHO

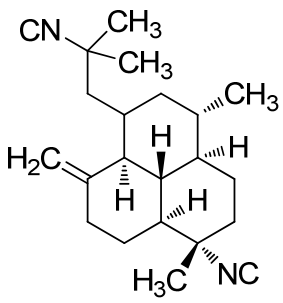

Amp21<smiles>C=C1CC[C@H]2[C@@H](C=C(C)C)C[C@@H](C)[C@@H]3CC[C@](C)(C#N)[C@H]2[C@H]13</smiles>

Amp26

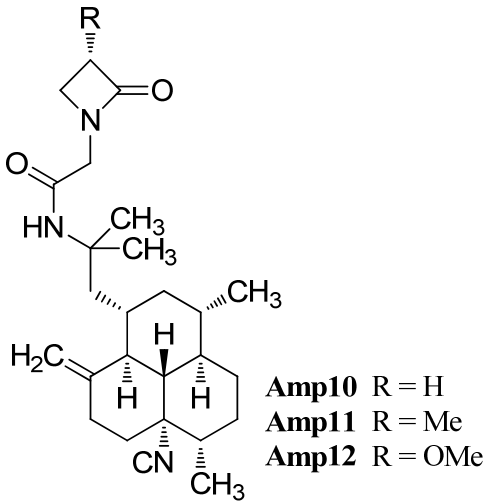<smiles>CC(C)=C[C@H]1C[C@@H](C)[C@H]2CC[C@](C)(C#N)[C@H]3CC=C(C)[C@H]1[C@@H]32</smiles>

Amp18

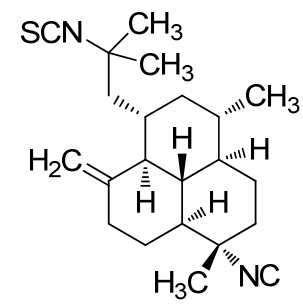

Amp22<smiles>CC(C)=CCCC(C)[C@H]1CC=C(C)[C@H]2CCC(C)=C[C@@H]21</smiles>

Amp27

Figure 24. Amphilectenes. 
The corresponding 15-thiocyanato derivative Amp3 was isolated in 2005 from the unidentified Caribbean sponge Cribochalina sp. by Ciavatta et al., who also were able to assign the absolute configuration of several amphilectenes based on an investigation of Amp1 by a modification of Mosher's method in 2005, revising a misassignment of the absolute configuration published in 1999 by the same group [118,120].

Further investigations of a Palauan sponge Halichondria sp. by Molinski et al. in 1987 resulted in the isolation of 8-isocyano-10,14-amphilectadiene (Amp5) bearing an isobutenyl side chain [121]. In 2004, Mitome et al. were able to find two double bond isomers $\left(1 S^{*}, 3 S^{*}, 4 R^{*}, 7 S^{*}\right.$, $\left.8 S^{*}, 12 S^{*}, 13 S^{*}\right)$-8-isocyanato-amphilecta-11(20),14-diene (Amp4) and $\left(3 S^{*}, 4 R^{*}, 7 S^{*}, 8 S^{*}, 11 S^{*}, 13 S^{*}\right)-8$ isocyanoamphilecta-1(12),14-diene (Amp6) in an unidentified Okinawan sponge Stylissa sp. taken from the coral reef of Iriomote Island (Japan) [50].

Another double bond isomer was identified in 2009 by Wattanapiromsakul et al. who were able to isolate 8-isocyanoamphilecta-11(20),15-diene (Amp7) from Ciocalapata sp. (family Halichondriidae), collected in Koh-Tao in the Surat-Thani province of Thailand [122].

Examination of the sponge Stylissa cf. massa, collected also in Koh-Tao (Thailand) by Chanthathamrongsiri in 2012 revealed two C-5 derivatives of Amp2, 8-isocyanato-15formamidoamphilect-11(20)-ene (Amp8) and 8-isothiocyanato-15- formamidoamphilect-11(20)-ene (Amp9) [123].

The isolation of three unprecedented $\beta$-lactam amphilectenes was reported in 2010 and 2015 by Avilés et al. from a Puerto Rican Hymeniacidon sp. (Demospongiae) collected in Mona Island [124,125]. The absolute configuration of monamphilectine A (Amp10), B (Amp11) and C (Amp12) was assigned by semisynthesis starting from 8,15-diisocyano-11(20)-amphilectene/((-)-DINCA) (Amp1). Monamphilectines B and $C$ bear a methyl and a methoxy group in $\alpha$-position of the $\beta$-lactam and represent the first $\alpha$-substituted $\beta$-lactams of marine origin.

Monoamphilectine A (Amp10) and Amp1 exhibited activity against Mycobacterium tuberculosis $\mathrm{H}_{37} \mathrm{Rv}$ with MIC values of $15.3 \mu \mathrm{g} / \mathrm{mL}$ and $3.2 \mu \mathrm{g} / \mathrm{mL}$, respectively [124].

7-Isocyano-11(20),14-epiamphilectadien (Amp13) or $\quad\left(1 R^{*}, 3 S^{*}, 4 R^{*}, 7 S^{*}, 8 S^{*}, 12 S^{*}, 13 S^{*}\right)-7$ isocyanoamphilecta-11(20),14-diene, isolated in 1980 by Kazlauskas from an Adocia species, was the first member of a series of amphilectanes bearing a 7-isonitrile substituent instead of a substituent at C-8 [126]. Its corresponding formamide $\left(1 R^{*}, 3 S^{*}, 4 R^{*}, 7 S^{*}, 8 S^{*}, 12 S^{*}, 13 S^{*}\right)$ 7-formamidoamphilecta-11(20),14-diene (Amp14) was found in 2009 by Wright et al. in the tropical marine sponge Cymbastela hooperi (Kelso Reef, Queensland, Australia) [127]. Already in 1996, an examination of the same sponge by König et al. had revealed among others the presence of five new 7-substituted amphilectenes, the $\Delta^{11,12}$-double bond isomer of Amp13 $\left(1 R^{*}, 3 S^{*}, 4 R^{*}, 7 S^{*}, 8 S^{*}, 13 R^{*}\right)-7$-isocyanoamphilecta-11,14-diene (Amp15), $\quad\left(1 S^{*}, 3 S^{*}, 4 R^{*}, 7 S^{*}, 8 S^{*}\right.$, $\left.12 S^{*}, 13 S^{*}\right)$-7-isocyano-amphilecta-10,14-diene (Amp18), the C-15 isothiocyanato exo-methylene derivative $\quad\left(1 S^{*}, 3 S^{*}, 4 R^{*}, 7 S^{*}, 8 S^{*}, 12 S^{*}, 13 S^{*}\right)$-7-isocyano-15-isothiocyanatoamphilecta-11(20)-ene (Amp22), and $\left(1 R^{*}, 3 S^{*}, 4 R^{*}, 7 S^{*}, 8 S^{*}, 12 R^{*}, 13 R^{*}\right)$-12-hydroxy-7-isothiocyanato-amphilecta-11(20),14-diene (Amp20), an unprecedented natural product which still represents the only example of an amphilectane containing an oxygen-based functional group [115].

The $\left(1 S^{*}, 3 S^{*}, 4 R^{*}, 7 S^{*}, 8 S^{*}, 12 S^{*}, 13 S^{*}\right)$-7-isocyanoamphilecta-11(20),15-ene (Amp16) also isolated by König, is probably identical with the so-called 7-isocyano-11(20),15-epiamphilectadiene that was described by Kazlauskas et al. in 1980 with an undetermined configuration at C-1 [115,126]. From the same sample, Kazlauskas was able to isolate 7,15-diisocyano-11(20)-epiamphilectene (Amp21) again with an uncertain stereochemistry at C-11.

Further investigation of a sample of Stylissa sp. by Mitome et al. revealed the C-1-epimer of Amp18 $\left(1 R^{*}, 3 S^{*}, 4 R^{*}, 7 S^{*}, 8 S^{*}, 12 S^{*}, 13 S^{*}\right)$-7-isocyanoamphilecta-10,14-diene (Amp19), while examination of Cymbastela hooperi by Wright et al. in 2009 resulted in the discovery of the formamide-derivative of Amp16, $\left(1 S^{*}, 3 S^{*}, 4 R^{*}, 7 S^{*}, 8 S^{*}, 12 S^{*}, 13 S^{*}\right)$-7-formamidoamphilecta-11(20),15-diene (Amp17) [50,127]. 
X-ray structural analysis of amphilectene metabolites from an unidentified Cribochalina species by Ciavatta et al. in 2005 led to the discovery of three members of the amphilectane class with a rather unusual cis-ring junction between C-8 and C-13, 7,15-diisocyano-11(20)-amphilectene (Amp23), its C15 isothiocyanato derivative 7-isocyano-15-isothiocyanato-11(20)-amphilectene (Amp24), as well as the isobutenyl derivative $(1 S, 3 S, 4 R, 7 S, 8 R, 12 S, 13 S)$-7-isocyanoamphilecta-11(20),15-diene (Amp25) which is the C-8-epimer of Amp16 [120].

In 2011, Lamoral-Theys et al. were able to reisolate compounds Amp1, Amp23 and Amp25 from the Caribbean sponge Pseudoaxinella flava from the Grand Bahamas along with a new representative with cis-junction Amp26. Amphilectenes Amp25 and Amp26 showed cytotoxic effects against the apoptosis-sensitive human PC3 prostate cancer cell line whereas Amp1 and Amp23 displayed cytostatic effects [128].

A putative precursor Amp27 of the amphilectene compounds with a biflora-4,9,15-triene skeleton was isolated by Hirota in 1996 [20]. The absolute configuration and a plausible biosynthetic pathway to the amphilectanes were reported in 2005 by Ciavatta [120].

Cycloamphilectenes

The first representative of the cycloamphilectanes (Figure 25), 8-isocyano-10-cycloamphilectene (Cam1) was isolated in 1980 by Kazlauskas et al. from an Adocia specimen [126]. The group also was able to detect traces of a second cycloamphilectane but due to the limited amount, the structure was initially misassigned. The correct relative configuration was reported in 1987 by Faulkner et al. who proved the compound to be $\left(3 S^{*}, 4 R^{*}, 7 S^{*}, 8 S^{*}, 11 S^{*}, 13 R^{*}\right)$-8-isocyano-1(12)-cycloamphilectene (Cam4) after reisolation from a Palauan Halichondria specimen [121].<smiles>[R]C1[C@H](C)CC[C@H]2[C@@H](C)C[C@@H]3CC(C)(C)CC4=CC[C@]12[C@H]43</smiles>

Cam1 R $=\mathrm{NC}$

Cam2 R $=$ NCS

Cam3 R $=$ NCO

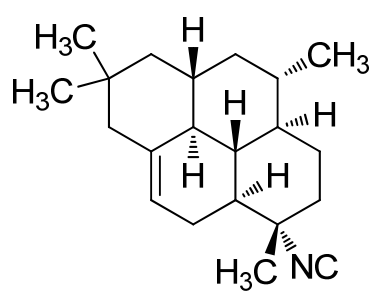

Cam7

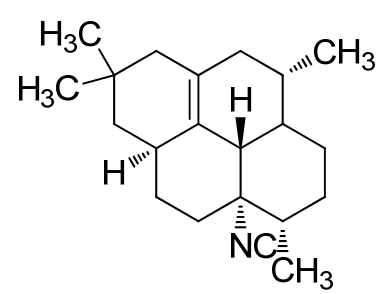

Cam4

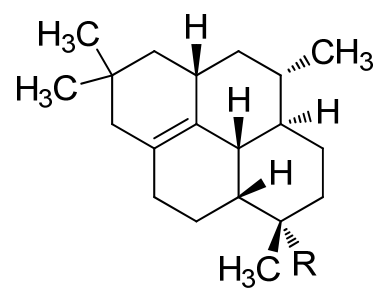

Cam8 R $=$ NC

Cam9 R $=$ NHCHO

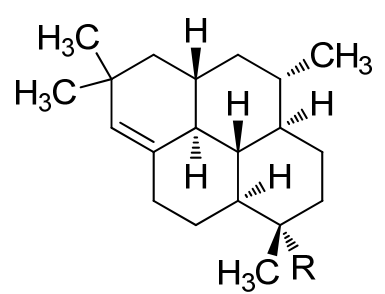

Cam5 R $=$ NC

Cam6 R $=$ NHCHO

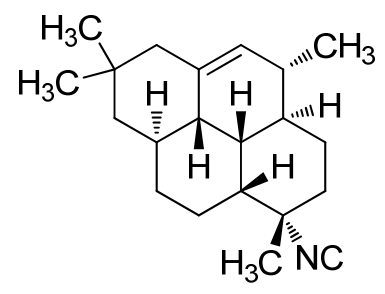

Cam10

Figure 25. Cycloamphilectenes.

In 2004, investigation of the Okinawan sponge Stylissa sp. by Mitome et al. resulted in the isolation of the isocyanato and isothiocyanato derivatives of Cam1, 8-isocyanatocycloamphilect-10-ene (Cam3) and 8-isothiocyanato-amphilect-10-ene (Cam2) [50]. Their absolute configuration was determined by anomalous X-ray dispersion of the corresponding semisynthetic 8-p-bromobenzamide derivative to be $1 S, 3 S, 4 R, 7 S, 8 S, 12 S, 13 S$. Cycloamphilectanes Cam 2 and Cam3 and amphilectanes Amp6 and Amp18 
displayed weak cytotoxicity towards HeLa cells showing $\mathrm{IC}_{50}$ values of $88.7 \mu \mathrm{g} / \mathrm{mL}, 38.3 \mu \mathrm{g} / \mathrm{mL}$, $11.2 \mu \mathrm{g} / \mathrm{mL}$, and $20.0 \mu \mathrm{g} / \mathrm{mL}$, respectively [50].

In 1996, the group around König was able to identify two 8-isocyano cycloamphilectanes in a sample of $C$. hooperi, the $\left(1 S^{*}, 3 S^{*}, 4 R^{*}, 7 S^{*}, 8 S^{*}, 12 S^{*}, 13 S^{*}\right)$-7-isocyanocylcoamphilect-10-ene (Cam7) and the $\left(1 S^{*}, 3 S^{*}, 4 R^{*}, 7 S^{*}, 8 S^{*}, 12 S^{*}, 13 S^{*}\right)$-7-isocyanocycloamphilect-11(20)-ene (Cam5) [115]. The formamide derivative of the latter compound, $\left(1 S^{*}, 3 S^{*}, 4 R^{*}, 7 S^{*}, 8 S^{*}, 12 S^{*}, 13 S^{*}\right)$-7-formamidocy cloamphilect-11(20)-ene (Cam6) was reported by Wright et al. in 2009 [127]. As for the amphilectenes, some members of the cycloamphilectenes with the uncommon 8,13-cis-junction are also known. The first two examples, $\left(1 S^{*}, 3 S^{*}, 4 R^{*}, 7 S^{*}, 8 R^{*}, 13 R^{*}\right)$-7-isocyano-11-cycloamphilectene (Cam8) and $\left(3 S^{*}, 4 R^{*}, 7 S^{*}, 8 R^{*}, 11 S^{*}, 12 R^{*}, 13 S^{*}\right)$-7-isocyano-1-cycloamphilectene (Cam10) were revealed in 1987 by Molinski et al. during their investigations of a Palauan Halichondria species [121]. In 2002, Ciasullo et al. were able to find the $\left(1 S^{*}, 3 S^{*}, 4 R^{*}, 7 S^{*}, 8 R^{*}, 13 R^{*}\right)$ - $N$-formyl-7-amino-11-cycloamphilectene (Cam9) in a sample of Axinella sp. from Vanuatu [129].

\section{Isocycloamphilectanes}

The first representative of the isocycloamphilectenes (Figure 26), which could be derived from amphilectene or cycloamphilectene precursors by a formal single methyl shift [126], was diisocyanoadociane or $(1 S, 3 S, 4 R, 7 S, 8 S, 11 S, 12 S, 13 S, 15 R, 20 R)-7,20$-diisocyanoisocycloamphilectane (Ica1), isolated already in 1976 by Baker from a sponge species of the genus Adocia (Great Barrier Reef, Townsville, Australia) [130]. Its absolute configuration was determined in 1988 by Fookes via X-ray analysis of its $p$-bromobenzamide derivative and was additionally proven by total synthesis (Corey 1987) [131,132]. The mono- and diformamido derivatives $(1 S, 3 S, 4 R, 7 S, 8 S, 11 S, 12 S, 13 S, 15 R, 20 R)$-7-formamido-10-isocyanoisocycloamphilectane (Ica5) and $(1 S, 3 S, 4 R, 7 S, 8 S, 11 S, 12 S, 13 S, 15 R, 20 R)-7,20$-diformamidoisocycloamphilectane (Ica6) were found by Wright in 2009 in a sample of Cymbastela hooperi [127]. Examination of the same species thirteen years earlier by König et al. resulted in the isolation of the isocyanato compounds $(1 S, 3 S, 4 R, 7 S, 8 S, 11 S, 12 S, 13 S, 15 R, 20 R)$-20-isocyano-7-isocyanatoisocycloamphilectane (Ica2) and $(1 S, 3 S, 4 R, 7 S, 8 S, 11 S, 12 S, 13 S, 15 R, 20 R)$-20-isocyanato-7-isocyanoisocycloamphilectane (Ica4) and the isothiocyanato derivative $(1 S, 3 S, 4 R, 7 S, 8 S, 11 S, 12 S, 13 S, 15 R, 20 R)$-20-isocyano-7-isothiocyanatoiso cycloamphilectane (Ica3) [115]. Apart from these, the group was also able to identify the monoolefinic derivative $\left(1 S^{*}, 3 S^{*}, 4 R^{*}, 7 S^{*}, 8 S^{*}, 11 R^{*}, 12 R^{*}, 13 S^{*}, 20 S^{*}\right)$-7-isocyanoisocycloamphilect-14-ene (Ica8).

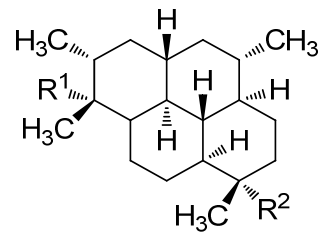

\begin{tabular}{ll}
\multicolumn{1}{c}{$\quad \mathbf{R}^{\mathbf{1}}$} & $\mathbf{R}^{\mathbf{2}}$ \\
Ica1 $\mathrm{NC}$ & NC \\
Ica2 $\mathrm{NC}$ & NCO \\
Ica3 $\mathrm{NC}$ & NCS \\
Ica4 $\mathrm{NCO}$ & NC \\
Ica5 NC & NHCHO \\
Ica6 $\mathrm{NHCHO}$ & NHCHO
\end{tabular}

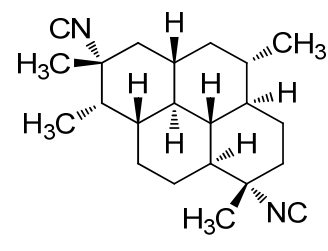

Ica7

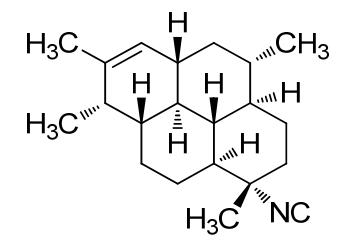

Ica8

Figure 26. Isocycloamphilectanes.

One example of an isocycloamphilectane with a different substitution pattern at C-15 and C-20 is known, the diisocyano compound 7,15-diisocyanoadociane (Ica7), isolated in 1980 by Kazlauskas [126,130]. 
Neoamphilectene

In 1992, a compound with an unusual amphilectane-framework in which ring $C$ is spirocyclic to the cyclohexene ring was found by Sharma in a sponge of the Adociae family, collected off the island of Miyako (Japan, Figure 27). To date 7-isocyanoneoamphilecta-11,15-diene (Neo1) remains the only known representative of its class [116].

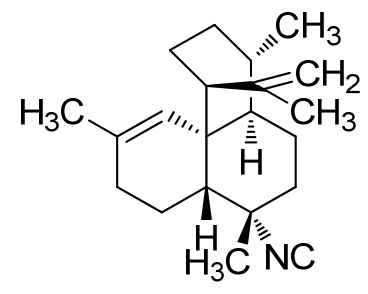

\section{Neo1}

Figure 27. Neopamphilectene.

Isoneoamphilectenes

In 1996, examination of $C$. hooperi by König et al. revealed the unique tricyclic diterpene 7-isocyanoneoamphilecta-1(14),15-diene (Ina1, Figure 28) [115]. It was not before 2013 that Avilés et al. were able to identify two further members of this class, the formamide derivative 7-formamidoisoneoamphilecta-1(14),15-diene (Ina2) and the unusual $\mathrm{N}$-methyl derivative 7-methylaminoisoneoamphilecta-1(14),15-diene (Ina3) in extracts of the Caribbean sponge Svenzea flava collected in Great Inagua Island, Bahamas [133]. Avilés et al. were able to determine the absolute configuration of these natural products to be $(3 S, 4 R, 7 S, 8 S, 11 R, 12 S, 13 R)$ by VCD-spectroscopy and DFT-calculations of the semisynthetic $\mathrm{NH}_{2}$-derivative Ina4.

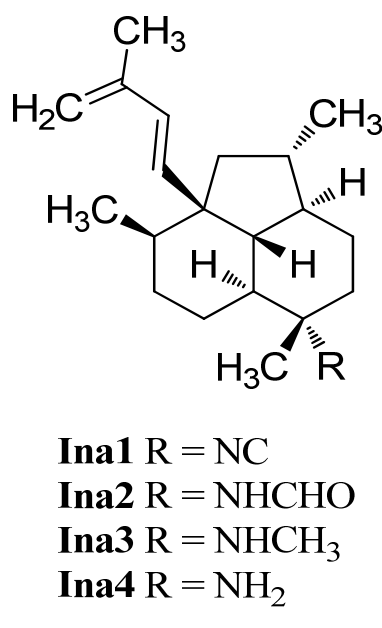

Figure 28. Isoneoamphilectenes.

Isoneoamphilectenes Ina1, 2, 3 and the semisynthetic Ina4 demonstrated strong growth inhibition potency against Mycobacterium tuberculosis $\mathrm{H}_{37} \mathrm{Rv}(\mathrm{MIC}=8 \mu \mathrm{g} / \mathrm{mL}, 15 \mu \mathrm{g} / \mathrm{mL}, 32 \mu \mathrm{g} / \mathrm{mL}$ and $6 \mu \mathrm{g} / \mathrm{mL}$, respectively) [133].

\subsection{Carbonimidic Dichlorides}

Carbonimidic dichlorides or dichloroimines represent a rare group of natural products of which to date only 16 representatives are known which are all of marine origin (Figures 29 and 30). They have been isolated from four marine sponges (Pseudaxinyssa pitys, Axinyssa sp., Stylotella aurantium and 
Ulosa spongia) and from the nudibranch Reticulidia fungia presumably feeding on these sponges. Carbonimidic dichlorides exhibit a strong IR absorption at $\sim 1650 \mathrm{~cm}^{-1}$ and a low intensity ${ }^{13} \mathrm{C}$ signal at $\delta \approx 127 \mathrm{ppm}$ and can therefore be unequivocally identified.

The first examples of this class of natural products were isolated in 1977 from the Indo-pacific marine sponge Pseudoaxinyssa pitys by Wratten, who identified the trans linear isoprenoid derivative Dcl2 containing three chlorines [134]. The substance was isolated again in 1997 by Simpson from Stylotella aurantium, a tropical marine sponge collected at Heron Island (Great Barrier Reef, Australia), and was named stylotellane B (Dcl2) [135]. The sponge also contained farnesyl isothiocyanate (Mis1) and Stylotellane A (Dcl1), a similar sesquiterpene without the chlorine substituent at C-2. Both stylotellanes were testet against tumor cell line P-388, however only a weak activity was observed for stylotellane B (Dcl 2).

Investigation of the Australian sponge Ulosa spongia collected at Wistari Reef (Great Barrier Reef, Australia) by König et al. in 2001 revealed the presence of ulosin A (Dcl3) which could be obtained from stylotellane B (Dcl2) by formal elimination of $\mathrm{HCl}$ and ulosin B (Dcl4) bearing three exo-methylene groups and two hydroxy groups at C-6 and C-10 [136]. Ulosin A was found independently from König in the same year also by Musman et al. in Okinawan Stylotella aurantium [137].<smiles>CC(C)=CCC/C(C)=C/CC/C(C)=C/CN=C(Cl)Cl</smiles>

Del1<smiles>C=C(CC/C=C(/C)CCC1OC1(C)C)C(Cl)CN=C(Cl)Cl</smiles><smiles>C=C(CC/C=C(/C)CCC=C(C)C)C(Cl)CN=C(Cl)Cl</smiles>

Dcl2<smiles>C=C(/C=C/N=C(Cl)Cl)CC/C=C(/C)CCC=C(C)C</smiles>

Del3<smiles>C=C(/C=C/N=C(Cl)Cl)CCC(O)C(=C)CCC(O)C(=C)C</smiles>

Dcl4
Del5<smiles>C=C(CC/C=C(\C)CC[C@@H](O)C(C)(C)O)C(Cl)CN=C(Cl)Cl</smiles>

Del6

Del7<smiles>[R]C1CC(=C(Cl)CN=C(Cl)Cl)C[C@@](C)(CCC=C(C)C)[C@H]1Cl</smiles>

Dcl8 $\mathrm{R}=\mathrm{OH}$

Dc19 $\mathrm{R}=\mathrm{H}$<smiles>C=C(CCC1C(=C)CCC(Cl)C1(C)C)C(Cl)CN=C(Cl)Cl</smiles>

Dcl10

Figure 29. Acyclic and monocyclic carbonimidic dichlorides. 
<smiles>CC1(C)C2CCC(/C=C\N=C(Cl)Cl)=C[C@@]2(C)C[C@H](O)[C@H]1Cl</smiles>

Del11<smiles>CC1(C)C2CCC(/C=C\N=C(Cl)Cl)=C[C@@]2(C)CC[C@@H]1Cl</smiles>

Del13<smiles>CC1(C)C2CC=C(/C=C\N=C(Cl)Cl)C[C@]2(C)C[C@H](O)[C@@H]1Cl</smiles>

Del12<smiles>CC1(C)[C@H]2CCC(/C=C/N=C(Cl)Cl)=C[C@@]2(C)CC[C@H]1Cl</smiles>

Del14<smiles>CC1(C)[C@H](Cl)[C@@H](O)C[C@]2(C)C=C(/C=C/N=C(Cl)Cl)CC[C@H]12</smiles>

Del15<smiles>CC1(C)[C@H](Cl)[C@@H](O)C[C@]2(C)CC(/C=C/N=C(Cl)Cl)=CC[C@H]12</smiles>

Del16<smiles>CC1(C)[C@H](Cl)[C@@H](O)C[C@]2(C)C=C(/C=C/N=C(Cl)Cl)CC[C@H]12</smiles>

Del17

Figure 30. Bicyclic carbonimidic dichlorides.

Examination of a marine sponge of the genus Axinyssa collected off Hachijo-jima Island (Japan) by Hirota et al. in 1998 led to the isolation of three new oxygenated sesquiterpenoid carbonimidic dichlorides [53]. Axinyssimide A (Dc15) represents the 10,11-epoxy derivative of stylotellane B while axinyssimides B (Dc16) and C (Dc17) turned out to be the 10,11-dihydroxy derivatives resulting from a ring-opening of the oxirane moiety. Axinyssimides $B$ and $C$, differing in magnitude and sign of their optical rotation, are diastereomers. All three compounds demonstrated potent antifouling activities against the cypris larvae of the acorn barnacle Balanus amphitrite with an $\mathrm{IC}_{50}$ value of $1.2 \mu \mathrm{g} / \mathrm{mL}$ for axinyssimide $\mathrm{A}, 70 \%$ inhibition at a concentration of $0.5 \mu \mathrm{g} / \mathrm{mL}$ for axinyssimide $\mathrm{B}$ and $90 \%$ inhibition at the same concentration for axinyssimide $C$ respectively [53].

Apart from stylotellane B, the investigation of Pseudoaxynissa pitys in 1977 by Wratten also revealed a monocyclic sesquiterpene containing the carbonimidic dichloride functionality [134]. This $\left(1 R^{*}, 5 S^{*}, 6 S^{*}\right)$-6,14-dichloro-5-hydroxy-9,3(14)-(Z)-axinyssadien-15yl-carbonimidic dichloride (Dcl8) was the first representative of a natural product with an axinyssane framework. In 2004, a second example without hydroxy goup at C-5 (Dc19) was discovered by Brust et al. [138].

Another monocyclic carbonimidic dichloride (Dcl10) was isolated in 2001 by Musman et al. from Stylotella aurantium collected from a coral reef of Iriomate Island (Okinawa, Japan) [137]. Both monocyclic carbon skeletons can be derived from Stylotellane B by an enzymatic chlorination including a formal "chloronium ion" initiated cyclization [139].

Further examination of the Pseudoaxinyssa pitys saple of Wratten in 1978 also revealed four examples of bicyclic sesquiterpenes with carbonimidic dichloride functionality [140]. Compound Dcl11, its $\Delta^{7,8}$-double bond isomer Dcl12 and the non-hydroxylated derivative Dcl13 all show a Z-configurated $\Delta^{14}$-double bond in the side chain. The fourth isolated isomer, isoreticulidin B (Dcl17) showing a $\Delta^{7,8}-14(E)$-diene system, was also found in the nudibranch Reticulidia fungia collected at Irabu Island (Okinawa) in 1999 by Tanaka et al. besides a monocyclic (Dcl8) and two bicyclic compounds that were named reticulidins A (Dcl15) and B (Dcl16) [141]. In 2001, Musman et al. were able to determine the absolute configuration of reticulidin A by a modification of Mosher's method to be $2 R, 3 R, 5 S, 10 S$ [137]. The same group also revealed the structure of the non-hydroxylated derivative Dcl14 of reticulidin A and isoreticulidin B isolated from Stylotella aurantium.

Dcl10 and Dcl14 exhibited moderate cytotoxicity showing $\mathrm{IC}_{50}$ values of $0.1-1 \mu \mathrm{g} / \mathrm{mL}$ against the tumor cell lines P-388, A549, HT29 and MEL28 [137]. Furthermore, reticulidins A (Dcl15) and B 
(Dcl16) showed moderate cytotoxic potency against $\mathrm{KB}$ cells ( $\mathrm{IC}_{50} 0.41$ and $0.42 \mu \mathrm{g} / \mathrm{mL}$ ) and L1210 cells $(0.59$ and $0.11 \mu \mathrm{g} / \mathrm{mL})$ [141].

\subsection{Other Marine Isonitriles and Related Compounds (Miscellaneous Structures)}

Among the isonitriles, isothiocyanates, and formamides of marine origin there are compounds that cannot be categorized in the structural families already presented (Figure 31).<smiles>[R]C/C=C(/C)CC/C=C(/C)CCC=C(C)C</smiles><smiles>CC(C)=CCC/C(C)=C/CC/C(C)=C\CN=O</smiles>

Mis4

Figure 31. Farnesyls.

Farnesylisothiocyanate (Mis1), an intermediate in the biosynthetic pathway of many sesquiterpene-isothiocyanates, was isolated in 1997 by Simpson from Stylotella aurantium [135,140]. Its corresponding formamide Mis2 and isofarnesyl formamide (Mis4) were found in 2008 in Axinyssa sp. collected in Sanya, Hainan Province, China by Li [84]. Until now, farnesyl isocyanide (Mis3) remains elusive which might be caused by the instability of this compound.

Apart from the marine isonitriles and isothiocyanates of terpenoid origin, a few examples with long saturated alkyl chains and structures related to sphingoids and lipids are also known (Figure 32). Investigation of the dorid nudibranch Actinocyclis papillatus collected at Wei Zhou Island (South China Sea, China) by Manzo et al. in 2011 resulted in the isolation of the unique ether lipid (R)-(-)-actisonitrile (Mis5) [142]. In 2008, Hung et al. reported the isolation of the ceramide (2R,3S)-2-formamido-1,3-dihydroxy-octadecane (Mis6) from the red alga Gracilaria verrucosa collected off the coast of Jeju Island, South Korea [143]. A further example, the sphingoid clavaminol L (Mis7), was isolated by Aiello et al. in 2009 from the Mediterranean ascidian Clavelina plegraea found in the Bay of Naples, Italy [144].<smiles>CCCCCCCCCCCCCCCOCC(N)COC(C)=O</smiles><smiles>CCCCCCCCCCCCCCCC[C@H](O)C(C#N)CNC(C)[C@H](CCCCCCCCC)OC(C)=O</smiles>

Figure 32. Lipid and amino alcohol derivatives.

In 1987, the investigation of an unidentified Fijian Pseudoaxinyssa species by Karuso/Scheuer resulted in the isolation of 21 mono- and diolefinic long-chain isothiocyanates (Figure 33). Eight diolefinic $\alpha, \omega$-bisisothiocyanates (Mis8-15) were found along with 10 monoolefinic 
$\alpha, \omega$-bisisothiocyanates (Mis16-25) and three monoolefinic $\alpha$-isothiocyanato- $\omega$-formyl derivatives (Mis26-28) [145].

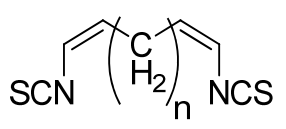

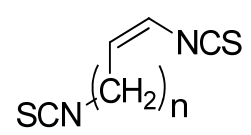

Mis26 $n=9$

Mis27 $n=15$

Mis28 $n=16$

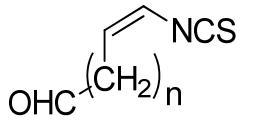

Figure 33. Long-chain isothiocyanates.

$$
\begin{array}{ll}
\operatorname{Mis16} n=9 & \operatorname{Mis21} n=14 \\
\operatorname{Mis17} n=10 & \operatorname{Mis22} n=15 \\
\operatorname{Mis18} n=11 & \operatorname{Mis23} n=16 \\
\operatorname{Mis19} n=12 & \operatorname{Mis24} n=17 \\
\text { Mis20 } n=13 & \text { Mis25 } n=18
\end{array}
$$

Examination of an Axinyssa sp. collected in the Andaman Sea (inner coral reef, Thailand) in 2014 by Cheng et al. revealed the bisabolene-based formamides axinyssine A (Mis29), axinyssine B (Mis30) and 1-acetyl-4-formamido-4-methylcyclohexane (Mis31, Figure 34) [92]. The corresponding isonitrile of Mis32 1-acetyl-4-isocyano-4-methylcyclohexane had already been discovered in the nudibranch Phyllidia sp. by Gulavita et al. in 1986 [74]. These four compounds could represent catabolic derivatives of the axinyssine sesquiterpenoids presented earlier.

Despite from the huge variety of marine isothiocyanates just a few examples of structures bearing a thiocyanate functionality are known (Figure 35). Among these is thiocyanatin A (Mis33) that was isolated from Oceanapia sp. (collected off the northern Rottnest shelf, Australia) in 2001 by Capon et al. together with its $\Delta^{8}$ - and $\Delta^{7}$-elimination products thiocyanatins B (Mis34) and C (Mis35) [146]. Thiocyanatin A was reported to possess in vitro nematicidal activities against the barber pole worm Haemonchus contortus whereas the non-hydroxylated derivatives thiocyanatins B and C showed no activity at all.<smiles>CC1(N=C=O)CCC(=O)CC1</smiles>

Mis29<smiles>C[C@H](O)C1CCC(C)(NC=O)CC1</smiles>

Mis30<smiles>CC(=O)C1CCC(C)(NC=O)CC1</smiles>

Mis31<smiles>CC(=O)[C@H]1CC[C@@](C)(C#N)CC1</smiles>

Mis32

Figure 34. Derivatives with $C_{7}$ - and $C_{9}$-carbon skeletons.

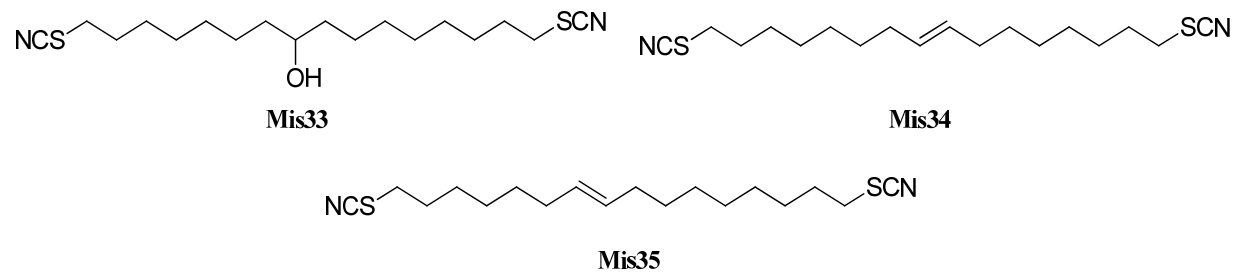

Figure 35. Thiocyanatins.

Three other thiocyanates with a unique carbon skeleton were found in the ascidian Clavelina cylindrica collected from the Bay of Islands (South Bruny Island, Tasmania) by Li et al. in 1994 (Figure 36) [147]. Cylindricines F (Mis40) and G (Mis41) show the same carbonyl skeleton as cylindricin A (Mis36) which was the first natural pyrrolo[2,1-j]quinoline to be identified. The isolation of cylindricine H (Mis30), the C-4-acetoxy-derivative of cylindricin G, was reported together with its corresponding isothiocyanate cylindricin I (Mis43) and the pyrido[2,1-j]quinoline isothiocyanate 
cylindricin J (Mis45), which shows the cylindricin B ring system (Mis44) [148]. Li also reported the interconvertibility of both ring systems.

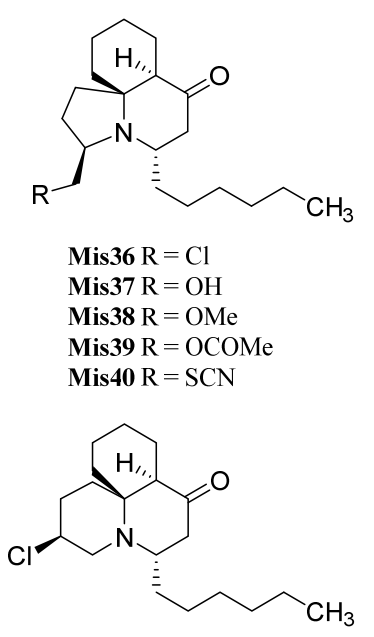

Mis44<smiles>CCCC[C@H]1CC(=O)C2CCCC3CC(CSC#N)N2C31</smiles>

Mis41

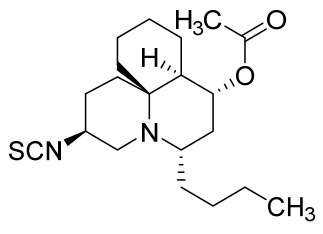

Mis45<smiles>[R]CC1CCC2CCCC3C(OC(C)=O)CC(CCCC)N(CCCC)C123</smiles>

$\operatorname{Mis} 42 \mathrm{R}=\mathrm{SCN}$ Mis43 R $=$ NCS

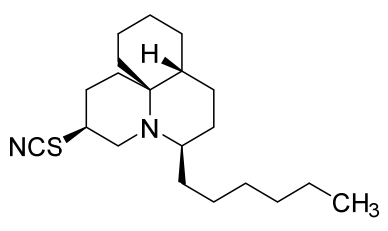

Mis46

Figure 36. Cylindricins and Fasicularin.

In 1997 Patil et al. reported the isolation of an thiocyanate derivative with a non-oxygenated pyrido[2,1-j]quinolin ring system from the Micronesian ascidian Nephteis fasicularis, which was named fasicularin (Mis46). It was demonstrated to have a selective activity against a DNA-repair deficient yeast strain and to be cytotoxic against Vero cells $\left(\mathrm{IC}_{50}=14 \mu \mathrm{g} / \mathrm{mL}\right)[149]$.

Another thiocyanate derivative was revealed when the investigation of the sponge Psammaplysilla purpurea by Jiménez and Crews in 1991 resulted in the isolation of the highly modified bromotyrosine-cysteine derivative psammaplin B (Mis47) showing antimicrobial activity against Gram-positive Staphylococcus aureus and mild tyrosine kinase inhibition potency $\left(\mathrm{IC}_{50}=2800 \mu \mathrm{M}\right)$ (Figure 37) [150].<smiles>N#CCCNC(=O)/C(Cc1ccc(O)c(Br)c1)=N/O</smiles>

Figure 37. Psammaplin B.

\section{Biosynthesis}

Two years after the first isolation of a marine isonitrile (Ax2) in 1973, Fattorusso et al. and Burreson et al. observed that the isonitriles are often occurred associated with the corresponding formamido and isothiocyanato analogues. Therefore, they speculated that the formamide function was the precursor for the isonitrile function which itself was the precursor for the isothiocyanate function $[5,6]$.

Iengo et al. fed the sponge Axinella cannabina with [ $\left.{ }^{14} \mathrm{C}\right]$-labeled axamide-1 (Ax4) over five days in well aerated sea water. No incorporation of the labeled formamide was observed and therefore the authors assumed that the formamide function is not the precursor for the isonitrile function. Nevertheless the authors questioned their own results because of several factors such as an insufficient incorporation rate [151]. 
Hagadone et al. performed experiments with the sponge Hymeniacidon sp. in its natural habitat. They synthesized $\left[{ }^{13} \mathrm{C}\right]$-labeled 2-formamidopupukeanane (Pu9) and 2-isothiocyanatopupukeanane and fed the sponges with these compounds. However, no $\left[{ }^{13} \mathrm{C}\right]$-labeled 2-isocyanopupukeanane (Pu7) was isolated after usual workup. Thereby neither the formamide function nor the isothiocyanato function appear to be the precursor for the isonitrile. Additionally, they observed, that $\left[{ }^{13} \mathrm{C}\right]$-formate is not a component in the biosynthesis of marine isonitriles. Finally, the sponge Hymeniacidon sp. was fed with $\left[{ }^{13} \mathrm{C}\right]$-labeled isocyanopupukeanane (Pu7) and appearance of labeled 2-formamidopupukeanane (Pu9) and 2-isothiocyanatopupukeanane, detected by GC-MS, demonstrated that the isonitrile function is the precursor for the formamido function as well as the isothiocyanato function [152].

Garson et al. demonstrated that cyanide is the source for the isonitrile carbons in diisocyanoadociane (Ica1). A marine sponge of the genus Amphimedon incorporated sodium $\left[{ }^{14} \mathrm{C}\right]$-cyanide and after usual workup Garson et al. isolated $\left[{ }^{14} \mathrm{C}\right]$-labeled diisocyanoadociane (Ica1). Zinc $\left[{ }^{14} \mathrm{C}\right]$-cyanide and isobutyraldehyde $\left[{ }^{14} \mathrm{C}\right]$-cyanohydrin are also effective precursors for this experiment due to their better solubility. Furthermore, the sponges were incubated with sodium $\left[2-{ }^{14} \mathrm{C}\right]$-acetate but it does not appear to be part of the biogenesis of diisocyanoadociane (Ica1). Nevertheless they detected labeled carotenoids. Finally they performed tracer studies with $\left[\mathrm{U}-{ }^{14} \mathrm{C}\right]$-alanine, $\left[2-{ }^{14} \mathrm{C}\right]$-glycine, $\left[\mathrm{U}-{ }^{14} \mathrm{C}\right]$-leucine and [guanidine- $\left.{ }^{14} \mathrm{C}\right]$-arginine but none of these amino acids are precursors for the isonitrile synthesis $[131,153]$.

Experiments with doubly labeled $\left[{ }^{13} \mathrm{C}_{1}^{15} \mathrm{~N}\right]$-cyanide were performed by Karuso and Scheuer with the sponge Ciocalypta sp. and showed that also the nitrogen in the isonitrile has its origin in cyanide. Moreover $\left[{ }^{14} \mathrm{C}\right]$-cyanide was also incorporated in the sponge Acanthella sp. which produces the diterpene kalihinol $\mathrm{F}$ (Kol21). Some evidence exists that several natural products isolated from sponges may actually have been synthesized by microrganisms associated with these sponges [154]. Thereby the biosynthesis of marine isonitriles differs distinctly from that in terrestrial microorganisms [155].

\subsection{Sesquiterpenoids}

All sesquiterpenoids are produced from farnesyl pyrophosphate (I) and by different cyclizations and Wagner-Meerwein rearrangements the various skeletons will be formed (Figure 38).

First, a 1,6-cyclization of farnesyl pyrophosphate (I) leads to the carbenium ion II which is the precursor for the bisabolanes (Bi1-Bi15) [156]. Furthermore, farnesyl diphosphate (I) can cyclize to the cyclodecane cation III. After formation of the cyclopropane ring with proton abstraction the bicycle IV can either convert by 1,5-cyclization to the aromadendranes (Ar2-Ar16) or by 1,6-cyclization to the epimaalianes (Ep1-Ep8) [157].

Additionally, farnesyl diphosphate (I) can convert to the bicycle VI with a cyclobutane ring and after 1,6-cyclization the tricyclic carbocation VIII is available which is the precursor for the epicaryolanes (So8) [94]. Furthermore, the carbenium ion VIII can transform by a 1,2-alkyl shift to the cation IX, which is the precursor for isocyanoclovane (So13) and isocyanoclovene (So12) [94].

Farnesyl diphosphate (I) can also cyclize to the cyclodecadiene cation III. After 1,5-cyclization of III, the guaianes (Gu1-Gu9) are available [157]. Through a 1,3-H shift and a following deprotonation XI is produced and after 1,6-cyclization, the precursor XII for the eudesmanes (Eu2-Eu33) is available. Additionally, the cation XII can convert by a Wagner-Meerwein rearrangement into the cation XIII which is the precursor for the axanes (Ax2-Ax10) [158].

In addition to the 1,6-cyclization to XII, $\mathbf{X I}$ can also transform to cation $\mathbf{X V}$ via 1,6-cyclization. Firstly, this carbocation XV is the precursor for the cadinanes (Ca2-Ca34) [44]. Secondly, after 1,2-H shift to the cation XVI and formation of a cyclopropane ring, the precursor XVII for the cubebanes (Fu9-Fu11) is formed [44]. Moreover, after a Wagner-Meerwein rearrangement of XVII to XVIII, the precursor for the spiroaxanes is obtained [44]. Finally, the cation $\mathbf{X V}$ can cyclize to the tricyclic system XX, which has two options for a 1,2-alkyl shift. The first option leads to cation XXI which is the precursor for the pupukeananes (Pu2-Pu10). The second option is a 1,2-alkyl shift to cation XXII which is the precursor for the neopupukeananes (Pu11-Pu13) [79]. 


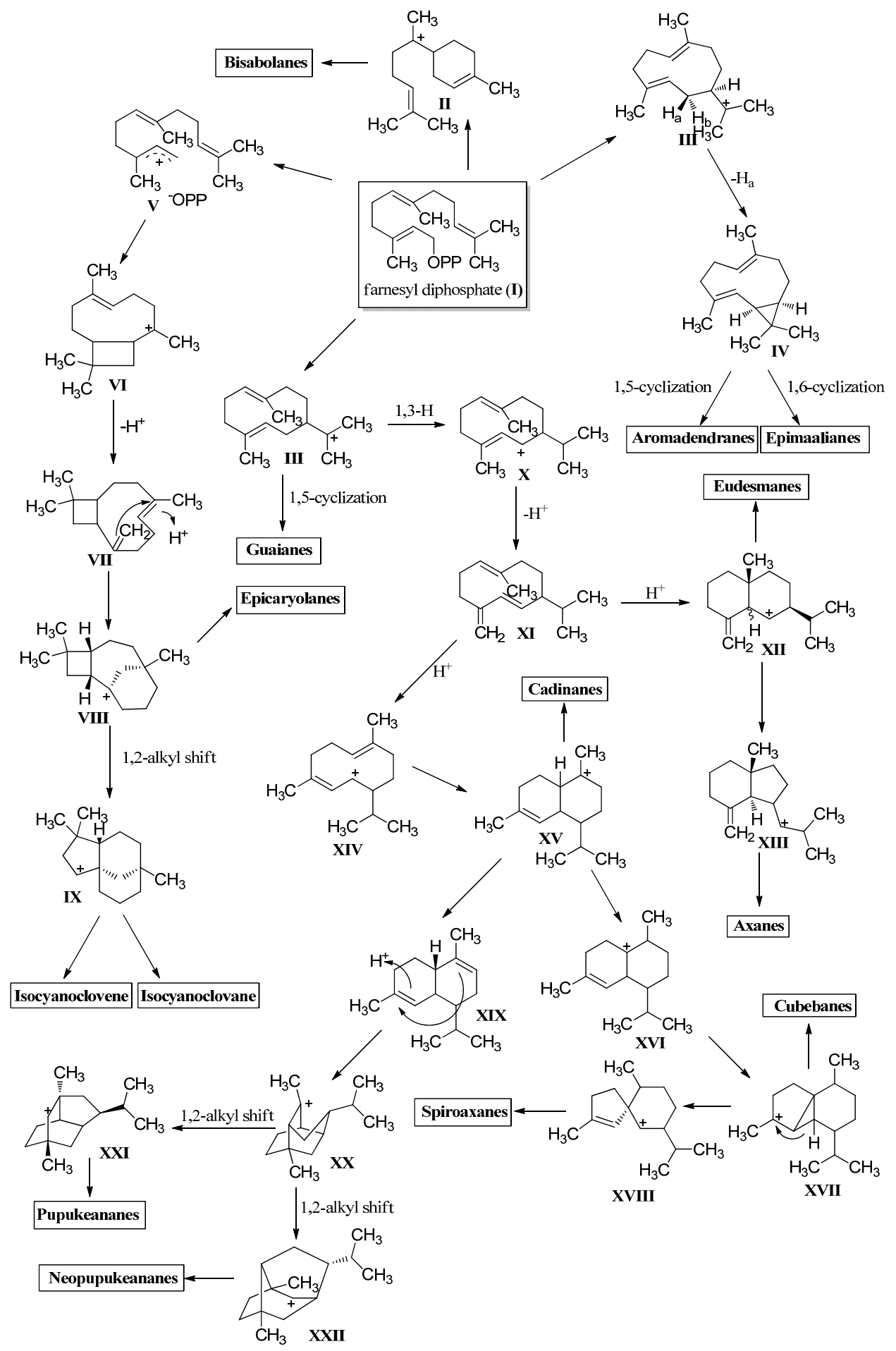

Figure 38. Proposed biosynthesis to sesquiterpenoids.

\subsection{Diterpenoids}

Rodriguez et al. proposed a possible biosynthetic pathway for diterpenoids in 1994 and postulated the ring closure by trans- and cis-cyclases [99]. Garson et al. extended the biosynthetic pathway to further structures in 2004 [14].

All Diterpenes are formed from the pyrophosphate XXIII (Figure 39). After integration of an additional double bond, the substrate XXIV can cyclize with a cis-cyclase to the $(4 S, 8 S)$-hexahydro naphthalene system $\mathbf{X X V}$ or with a trans-cyclase to the $(4 R, 8 S)$-hexahydronaphthalene system $\mathbf{X X V I I}$. 


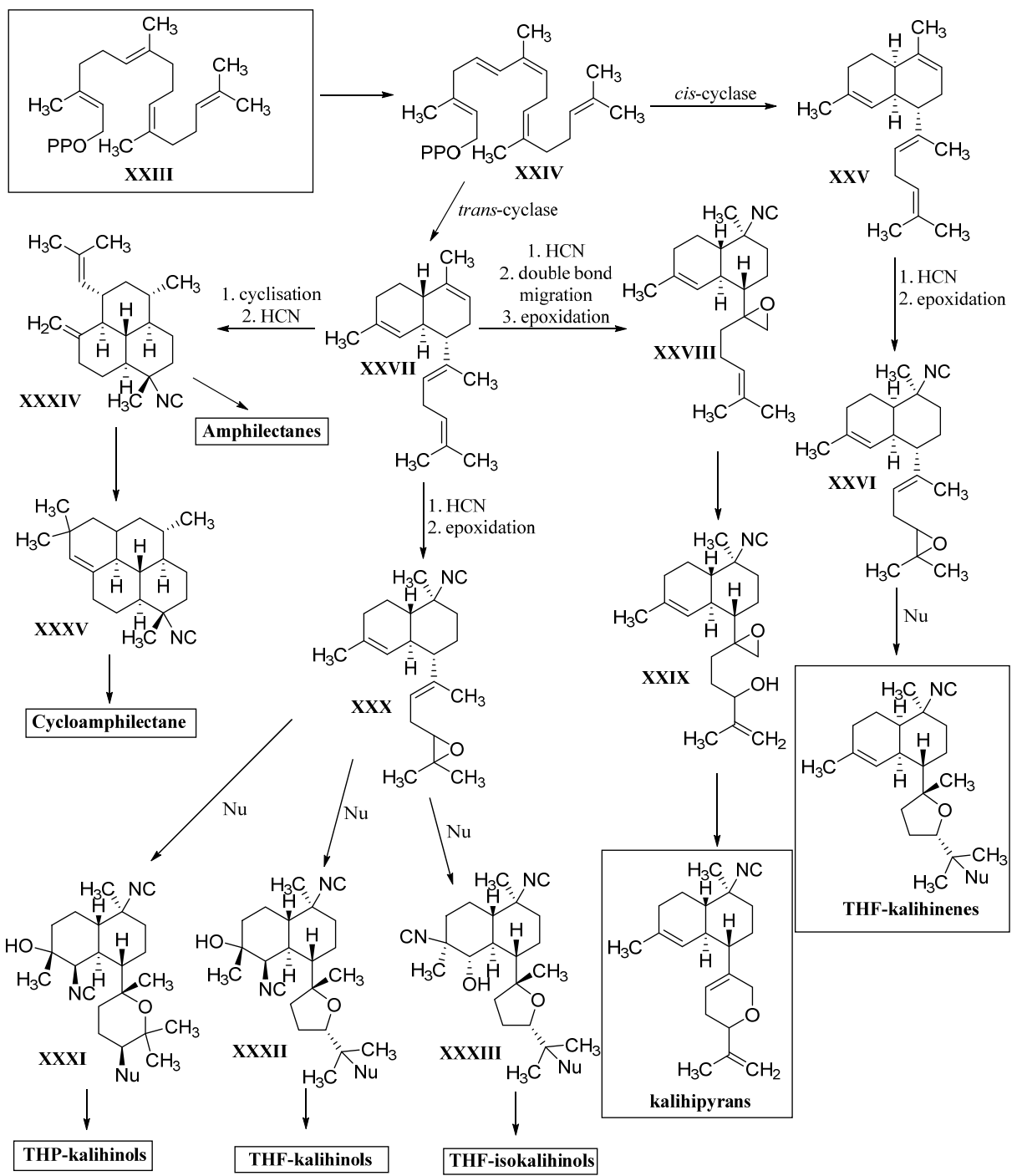

Figure 39. Proposed biosynthesis of diterpenoids [12,14,99].

After addition of hydrogen cyanide and epoxidation of XXV to XXVI, a nucleophile can attack the epoxide under ring opening and the resulting alcohol can attack at the double bond under formation of the tetrahydrofuran ring in the THF-kalihinenes (Ken1-Ken12) [14,99].

For the other marine diterpenes $(4 R, 8 S)$-hexahydronaphthalene system XXVII is the origin. After addition of hydrogen cyanide, a double bond migration and an epoxidation form the epoxide XXVIII. In further steps, the hydroxylated epoxide XXIX is formed and after nucleophilic attack of the hydroxy group at the epoxide and subsequent elimination of water, the biogenesis of the kalihipyrans (Kpy1-Kpy4) is achieved [14,100].

After addition of hydrogen cyanide and epoxidation of XXVII without double bond migration, epoxide XXX is generated. Garson and Simpson postulated the attack of a nucleophile at both positions of the epoxide XXX and after attack of the oxyanion at the double bond under ring closure either the THP-kalihinols (Kol1-Kol19) or the THF-kalihinols (Kol20-Kol34) or isokalihinols (Kol35-Kol41), respectively, should be formed $[14,99]$. The hydroxy and isonitrile function at C-4 or C-5, respectively, are established by epoxidation of the double bond and following nucleophilic attack at C-4 or C-5.

A further option for the $(4 R, 8 S)$-hexahydronaphthalene system XXVII is an additional cyclization and subsequent addition of hydrogen cyanide to the dodecahydrophenalene system XXXIV which represents the precursor for the amphilectanes (Amp1-Amp26). Moreover, a further cyclization of 
XXXIV to the tetradecahydropyrene system XXXV provides the precursor for the cycloamphilectanes (Cam1-Cam10) [14,99].

\subsection{Carbonimidic Dichlorides}

Along with the discovery of the carbonimidic dichlorides in 1977, Wratten already proposed the hypothesis that this uncommon functionality may result from enzymatic chlorination of the corresponding isonitriles or isothiocyanates (Figure 40) [134]. Feeding experiments using radioactive inorganic cyanide in 1997 by Simpson et al. proved this hypothesis to be correct [135].

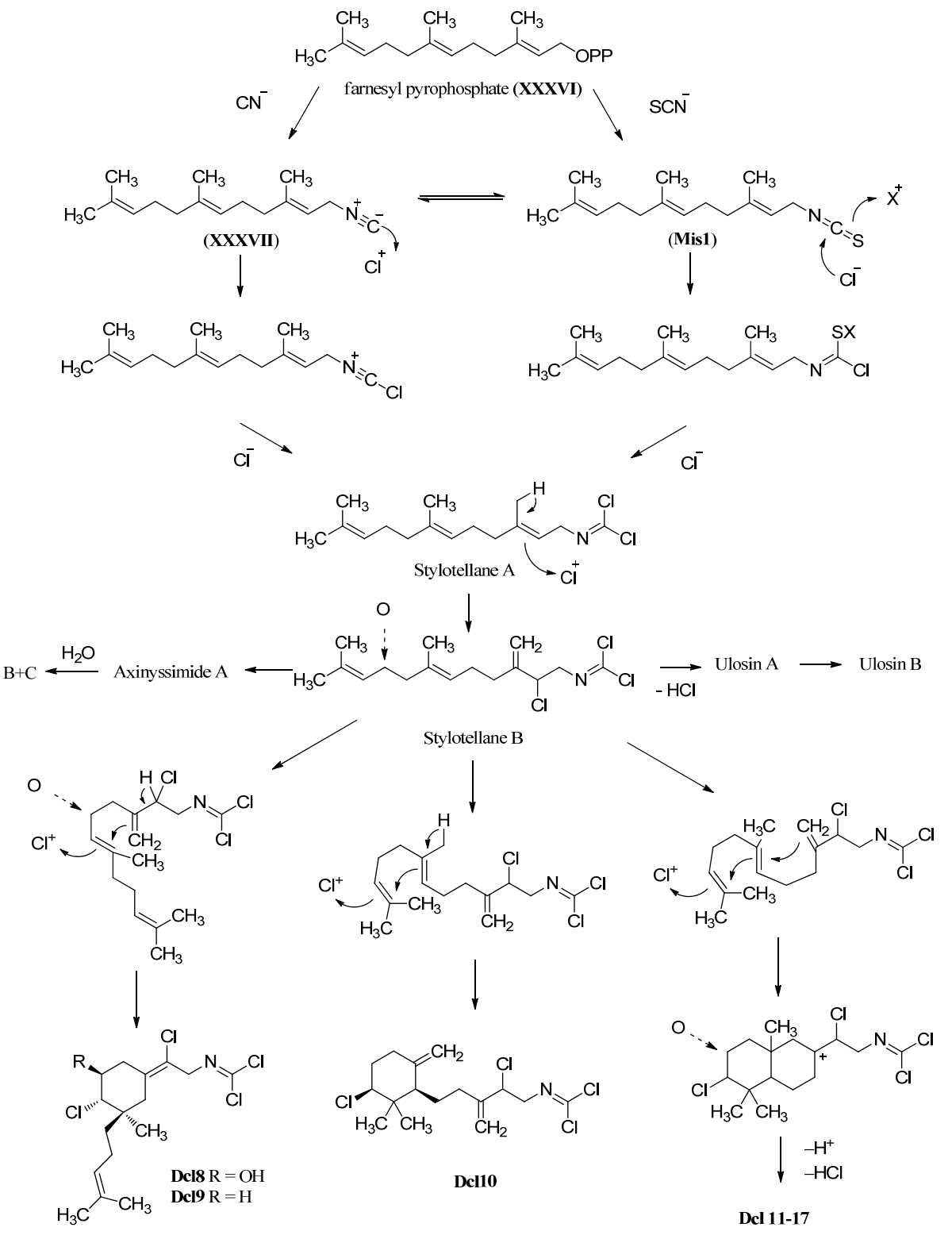

Figure 40. Proposed biosynthesis of carbonimidic dichlorides.

Starting from farnesyl pyrophosphate (XXXVI), they were able to show the presence of radioactive stylotellane A in Stylotella aurantium fed with potassium $\left[{ }^{14} \mathrm{C}\right]$-cyanide or isothiocyanate. It could be biosynthesized from farnesyl isocyanide (XXXVII) as well as from the corresponding farnesyl isothiocyanate (Mis1). Through enzymatic chlorination, stylotellane A can be converted into stylotellane B which is the precursor for both monocyclic carbon skeletons as well as for the bicyclic sesquiterpenoid derivatives, which all result from an enzyme catalyzed chlorinating cyclization. 
Hydroxylation could either occur from allylic oxidation of stylotellane B at C-9 or after the cyclization. Investigations of the biosynthetic pathway to the cyclic carbonimidic dichlorides were performed by Simpson et al. in 2004 using further feeding experiments [139].

\section{Biological Activity}

In general, marine isonitriles have a weak to moderate activity in mammalian cell cytotoxicity assays (10-100 $\mu \mathrm{M})$ against a broad range of cell lines [15]. Toxicity studies of simple isonitriles revealed surprisingly low toxicity with oral and subcutaneous toxic doses up to $\mathrm{LD}_{50}=5 \mathrm{~g} / \mathrm{kg}$ [159].

Ireland and coworkers reported on the antibacterial activity of kalihinols A (Kol1), F (Kol21), G (Kol24), J (Kol13), X (Kol4), Y (Kol9), 10-formamido-kalihinol F (Kol22), 15-formamido-kalihinol F (Kol23) and kalihinene (Ken1) on the basis of inhibition of the bacterial folate biosynthesis as well as on the growth inhibition of Bacillus subtilis [109]. The most potent substances tested were the pyranyl-type kalihinols Y (Kol9) and X (Kol4), each showing an MIC of $1.56 \mu \mathrm{g} / \mathrm{mL}$. Nevertheless, negative results of selectivity tests for the folate biosynthesis inhibition mechanism strongly suggest an additional mechanism of action for the pyranyl-bearing derivatives. The furanyl type kalihinols F (Kol21) and G (Kol24) and kalihinene (Ken1) on the other hand are more selective inhibitors than the pyranyl type kalihinols. The substitution pattern at C-10 seems to be important for the potency which becomes apparent in the loss of activity for kalihinol A (Kol1) which just differs in the orientation of the isonitrile group at C-10 from the highly active kalihinols Y (Kol9) and X (Kol4) which bear an exo-methylene and an isothiocyanate group, respectively. Finally, the presence of a formamido-substituent, irrespective of its position, is accompanied by a significiant decrease of activity which may be caused by a diminished cellular uptake [109].

Recently, Mayer et al. reported that several amphilectanes (Amp1, 2, 10, 23 and 25) exhibit promising anti-inflammatory effects, measured in an assay on thromboxane $B_{2}$ and superoxide anion generation from Escherichia coli LPS-activated rat brain microglia [160]. Furthermore, several amphilectanes with antimalarial [115,122,127], anti-microbial [102,119,121,126], anti-fungal [112], cytotoxic [50,110], anti-fouling [20], anti-algal [161], anti-tubercular [124,133,161] and anti-photosynthetic [161] activity were reported.

The most promising biological activity of marine isonitriles and their related compounds is their antimalarial activity. A large part of the humanity lives in malaria endangered regions. In 1996, Wright and König gave an overview of the antimalarial effects [115].

Isocycloamphilectenes Ica 1, 2, 3, 4 and 9, cycloamphilectenes Cam 5 and 7, amphilectenes Amp 13, 15, 16, 18, 20 and 22, isoneoamphilectene Ina1, eudesmanes Eu17 and Eu21 and axisonitrile-3 (Sp2) all demonstrated significiant in vitro activity against the malaria parasite Plasmodium falciparum [115,162]. Investigations by Wright and König revealed the isocycloamphilectenes diisocyanoadociane (Ica1) and (Ica4) to display the highest antimalarial activity and selectivity with $\mathrm{IC}_{50}$ values of $4 \mathrm{nM}$ and $9 \mathrm{nM}$, respectively. Structure-activity relationship studies for the amphilectane derivatives using computer-based molecular modeling resulted in the conclusion that the orientation of the C-4 side chain and the negative electrostatic potential in the region of C-7 have a major impact on the activity of these compounds. An $\alpha$-orientation of the C-4 side chain as for amphilectenes Amp16, 18 and 22 results in a decrease of activity due to unfavourable steric influences, which also occur with the $\mathrm{OH}$-group of compound Amp20. An isonitrile group at C-7 shows best results for the antimalarial activity. Another functional group at this center or a migration of the $\Delta^{11,20}$-exo-double bond of Amp13 to $\Delta^{11,12}$ (Amp15) causes a distinct loss of antiplasmodial activity, whereas the KB cytotoxicity stays almost unaffected. On the other hand, the nature of the C-20-functionality seems to have no influence on the activity [162]. In agreement with these findings are the results of Chanthathamrongsiri et al. who proved the C-8 isonitrile Amp2 to have a tenfold higher antiplasmodial activity than the isocyanate (Amp8) and the isothiocyanate Amp9. The C-7-formamide Amp17 was inactive [123].

The $\beta$-lactam bearing amphilectenes monoamphilectines A (Amp10), B (Amp11) and C (Amp12) demonstrated $\mathrm{IC}_{50}$ values of $0.60 \mu \mathrm{g} / \mathrm{mL}$ against the chloroquine-resistant $\mathrm{W} 2$ strain of $P$. falciparum 
for Amp10 and $44.5 \mathrm{nM}$ and $43.3 \mathrm{nM}$ against wild-type P. falciparum 3D7 strain for Amp11 and Amp12, respectively [124,125].

In a series of investigations Wright et al. showed that the high antiplasmodial activity of Ica1 $\left(\mathrm{IC}_{50}=4 \mathrm{nM}\right)$, Amp13 $\left(\mathrm{IC}_{50}=47 \mathrm{nM}\right)$ and Cam5 $\left(\mathrm{IC}_{50}=24 \mathrm{nM}\right)$ may arise from the inhibition of detoxification processes in P. falciparum. Ica1 and, to a lesser degree, Amp13 and Cam5, inhibit the crystallization of free-heme (ferriprotoporphyrin IX) to hemozoin which may cause a colloidal osmotic instability in P. falciparum. Additionally, a concomitant impairment of $\mathrm{H}_{2} \mathrm{O}_{2}$ detoxification processes may arise $[41,161,163]$.

Both effects are attributed to an interaction of the marine isonitriles with hemoglobin in a cavity close to heme [41]. Initial studies proposed a direct binding to the free heme iron [161].

In spite of the variety of marine isocyanoterpenoids showing promising antimalarial activity, only a few kalihinane-type isonitriles have been evaluated for their potency in this respect. In 1998, Miyaoka demonstrated kalihinol A (Kol1) to have potent antimalarial activity against the drug-resistant FCR-3 strain of Plasmodium falciparum $\left(\mathrm{IC}_{50}=1.2 \mathrm{nM}\right)$ while 10-epi-kalihinol I (Kol15), 5,10-bisisothiocyanatokalihinol G (Kol34), kalihinene (Ken1) and 6-hydroxy-kalihinene (Ken5) were somewhat less active [105].

In 2015, Daub et al. proved kalihinol B (Kol) to exhibit antiplasmodial activity $\left(\mathrm{IC}_{50}=8.4 \mathrm{nM}\right.$ for the wild type of the 3D7 strain of P. falciparum and $4.6 \mathrm{nM}$ for chloroquine-resistant Dd2 strain) in a similar range as kalihinol A (Kol1). The group developed a twelve-step synthesis towards kalihinol B (Kol20), thus establishing a synthetic route to other kalihinol derivatives for further antiplasmodial testing [164].

As is obvious from the promising activities against P. falciparum, the marine isonitriles may well be viewed as attractive lead structures for new drugs against malaria.

\section{Conclusions}

Since the last review on marine isonitriles in 2000, the number of isolated marine isonitriles and their related compounds has continued to increase steadily (Figure 41). Today, the marine isonitriles and their derivatives are still very interesting molecules in terms of their structure, their biosynthesis, and their potential application in the biomedical field. Although it can safely be assumed that the malaria parasite Plasmodium falciparum and the isonitrile-bearing marine organisms have never met in recent evolution, the pronounced antimalarial activity of natural isonitriles is one of several reasons to continue research on these odd, yet fascinating molecular gemstones from the oceans.

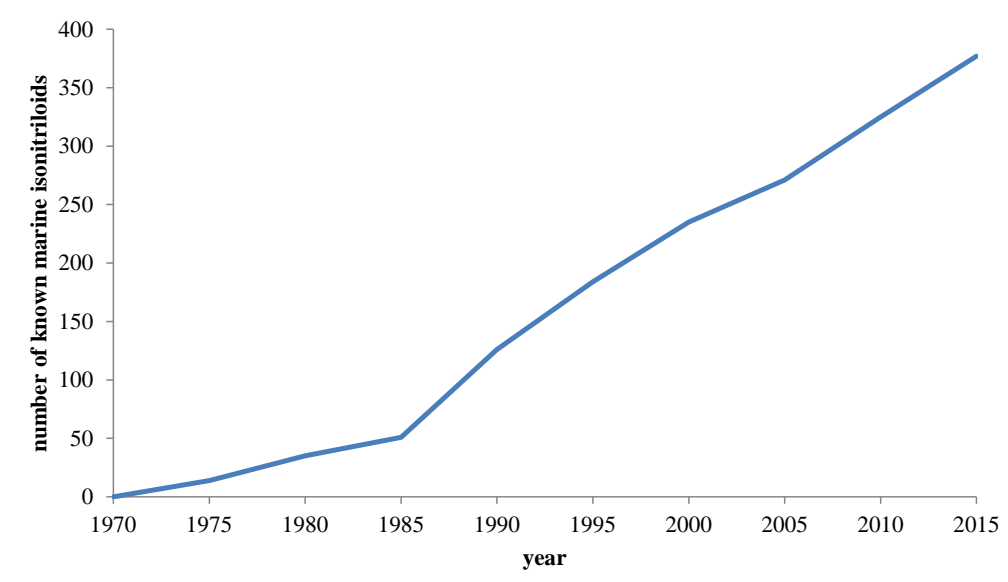

Figure 41. Number of new marine isonitriles and related compounds found until 2015.

\section{Overview about All Marine Isonitriles and Their Related Compounds}

All known marine isonitriloids are listed in the following table (Table 1). 
Table 1. Overview of all known marine isonitriles and their related compounds.

\begin{tabular}{|c|c|c|c|c|}
\hline Trivial Name (Structure) & Organism & Origin & Year & References \\
\hline \multicolumn{5}{|c|}{ Sesquiterpenoids } \\
\hline \multicolumn{5}{|c|}{ Axanes } \\
\hline axisonitrile-1 (Ax2) & Axinella cannabina & Bay of Taranto, Italy & 1973 & [2] \\
\hline axisothiocyanate-1 (Ax3) & Axinella cannabina & Bay of Taranto, Italy & 1973 & [2] \\
\hline axamide-1 (Ax4) & Axinella cannabina & Bay of Taranto, Italy & 1974 & {$[4]$} \\
\hline axisonitrile-4 (Ax5) & Axinella cannabina & Bay of Taranto, Italy & 1977 & {$[16]$} \\
\hline axisothiocyanate-4 (Ax6) & Axinella cannabina & Bay of Taranto, Italy & 1977 & [16] \\
\hline axamide-4 (Ax7) & Axinella cannabina & Bay of Taranto, Italy & 1977 & {$[16]$} \\
\hline \multirow{2}{*}{ cavernoisonitrile (Ax8) } & Acanthella cf. cavernosa & Hachijo-jima Island, Japan & 1992 & [19] \\
\hline & Acanthella cavernosa & Hachijo-jima Island, Japan & 1996 & [20] \\
\hline \multirow{2}{*}{ (-)-cavernothiocyanate (Ax9) } & Acanthella cf. cavernosa & Hachijo-jima Island, Japan & 1992 & [19] \\
\hline & Acanthella cavernosa & Hachijo-jima Island, Japan & 1996 & [20] \\
\hline \multirow{3}{*}{ 10-isothiocyanato-11-axene (Ax10) } & Acanthella cf. cavernosa & Hachijo-jima Island, Japan & 1992 & [19] \\
\hline & Phyllidia ocellata & Hachijo-jima Island, Japan & 1992 & [19] \\
\hline & Acanthella cavernosa & Hachijo-jima Island, Japan & 1996 & {$[20]$} \\
\hline
\end{tabular}


Table 1. Cont

\begin{tabular}{|c|c|c|c|c|}
\hline Trivial Name (Structure) & Organism & Origin & Year & References \\
\hline \multicolumn{5}{|c|}{ Eudesmanes } \\
\hline \multirow{2}{*}{ acanthellin-1 (Eu2) } & Acanthella acuta & Bay of Naples, Italy & 1974 & [3] \\
\hline & Axinella cannabina & Bay of Taranto, Porto Cesareo, Italy & 1984 & {$[21]$} \\
\hline $\mathrm{R}=\mathrm{NCS}(\mathrm{Eu} 3)$ & Axinella cannabina & Bay of Taranto, Porto Cesareo, Italy & 1984 & {$[21]$} \\
\hline $\mathrm{R}=\mathrm{NHCHO}(\mathbf{E u} 4)$ & Axinella cannabina & Bay of Taranto, Porto Cesareo, Italy & 1984 & [21] \\
\hline $\mathrm{R}=\mathrm{NC}(\mathbf{E u} 5)$ & Axinella cannabina & Bay of Taranto, Porto Cesareo, Italy & 1984 & [21] \\
\hline R=NCS (Eu6) & Axinella cannabina & Bay of Taranto, Porto Cesareo, Italy & 1984 & [21] \\
\hline $\mathrm{R}=\mathrm{NHCHO}(\mathbf{E u 7})$ & Axinella cannabina & Bay of Taranto, Porto Cesareo, Italy & 1984 & {$[21]$} \\
\hline $\begin{array}{c}6 \alpha \text {-isocyano- } 5 \alpha-\mathrm{H}, 7 \alpha-\mathrm{H} \\
10 \alpha \text {-eudesm- } 4(14) \text {-ene (Eu8) }\end{array}$ & Axinella cannabina and Acanthella acuta & Bay of Taranto, Porto Cesareo, Italy & 1987 & [22] \\
\hline $\begin{array}{l}6 \alpha \text {-isothiocyano- } 5 \alpha-\mathrm{H}, 7 \alpha-\mathrm{H} \\
10 \alpha \text {-eudesm- } 4(14) \text {-ene (Eu9) }\end{array}$ & Axinella cannabina and Acanthella acuta & Bay of Taranto, Porto Cesareo, Italy & 1987 & {$[22]$} \\
\hline $\begin{array}{c}6 \alpha \text {-formamido- } 5 \alpha-\mathrm{H}, 7 \alpha-\mathrm{H} \\
10 \alpha \text {-eudesm- } 4(14) \text {-ene }(\text { Eu10) }\end{array}$ & Axinella cannabina & Bay of Taranto, Porto Cesareo, Italy & 1987 & {$[22]$} \\
\hline \multirow[b]{2}{*}{ halichonadin C (Eu11) } & Halichondria sp. & Unten Port, Okinawa, Japan & 2005 & {$[24]$} \\
\hline & Phyllidia ocellata & Mudjimba Island, Mooloolaba, Australia & 2015 & [94] \\
\hline \multirow{2}{*}{ acanthene B (Eu12) } & Acanthella sp. & $\begin{array}{l}\text { Conehead Point, Rennell Sound, } \\
\text { Graham Island, British Columbia }\end{array}$ & 1993 & [23] \\
\hline & Acanthella cavernosa & $\begin{array}{c}\text { Tani's Reef, Gneerings Reef, Mooloolaba, } \\
\text { Australia }\end{array}$ & 2007 & {$[32,58]$} \\
\hline acanthene C (Eu13) & Cadlina luteomarginata & $\begin{array}{l}\text { Conehead Point, Rennell Sound, } \\
\text { Graham Island, British Columbia }\end{array}$ & 1993 & [23] \\
\hline halichonadin B (Eu14) & Halichondria sp. & Unten Port, Okinawa, Japan & 2005 & [24] \\
\hline halichonadin A (Eu15) & Halichondria sp. & Unten Port, Okinawa, Japan & 2005 & [24] \\
\hline
\end{tabular}


Table 1. Cont

\begin{tabular}{|c|c|c|c|c|}
\hline Trivial Name (Structure) & Organism & Origin & Year & References \\
\hline \multirow{6}{*}{ 11-isocyano-7 $\beta$-H-eudesm-5-ene (Eu16) } & Axinella cannabina & Taranto, near Porto Cesareo, Italy & 1987 & {$[25]$} \\
\hline & Phyllidia pustulosa & $\begin{array}{l}\text { Negros Island, Cebu Island, San Sebastian, } \\
\text { Cebu, Philippines }\end{array}$ & 1991 & {$[86]$} \\
\hline & $\begin{array}{l}\text { Acanthella sp. and } \\
\text { Cadlina luteomarginata }\end{array}$ & $\begin{array}{l}\text { Conehead Point, Rennell Sound, Graham } \\
\text { Island, British Columbia }\end{array}$ & 1993 & [23] \\
\hline & Axinyssa ambrosia & $\begin{array}{c}\text { Santa Marta Bay, Caribbean Coast, } \\
\text { Colombia }\end{array}$ & 2002 & {$[26]$} \\
\hline & Acanthella cavernosa & $\begin{array}{c}\text { Tani's Reef, Gneerings Reef, Mooloolaba, } \\
\text { Australia }\end{array}$ & 2007 & {$[32,58]$} \\
\hline & Phyllidiella pustulosa & Vietnam & 2010 & [27] \\
\hline \multirow{7}{*}{ 11-isothiocyano-7 $\beta$-H-eudesm-5-ene (Eu17) } & Axinella cannabina & Taranto, near Porto Cesareo, Italy & 1987 & {$[25]$} \\
\hline & Acanthella pulcherrima & Weed Reef, Darwin, Australia & 1988 & [28] \\
\hline & Phyllidia pustulosa & $\begin{array}{l}\text { Negros Island, Cebu Island, San Sebastian, } \\
\text { Cebu, Philippines }\end{array}$ & 1991 & {$[86]$} \\
\hline & Acanthella klethra & Pelorus Islands, Queensland, Australia & 1992 & {$[30]$} \\
\hline & $\begin{array}{l}\text { Acanthella sp. and } \\
\text { Cadlina luteomarginata }\end{array}$ & $\begin{array}{l}\text { Conehead Point, Rennell Sound, Graham } \\
\text { Island, British Columbia }\end{array}$ & 1993 & [23] \\
\hline & Axinyssa ambrosia & $\begin{array}{c}\text { Santa Marta Bay, Caribbean Coast, } \\
\text { Colombia }\end{array}$ & 2002 & [26] \\
\hline & Acanthella cavernosa & $\begin{array}{l}\text { Coral Gardens, Gneerings Reef, } \\
\text { Mooloolaba, Australia }\end{array}$ & 2007 & {$[32,58]$} \\
\hline \multirow{2}{*}{ 11-formamido-7 $\beta$-H-eudesm-5-ene (Eu18) } & Axinella cannabina & Taranto, near Porto Cesareo, Italy & 1987 & {$[25]$} \\
\hline & Axinyssa ambrosia & $\begin{array}{c}\text { Santa Marta Bay, Caribbean Coast, } \\
\text { Colombia }\end{array}$ & 2002 & {$[26]$} \\
\hline 4-Isothiocyanatoeudesm-11-ene (Eu19) & Axinyssa ambrosia & $\begin{array}{c}\text { Santa Marta Bay, Caribbean Coast, } \\
\text { Colombia }\end{array}$ & 2002 & {$[26]$} \\
\hline
\end{tabular}


Table 1. Cont

\begin{tabular}{|c|c|c|c|c|}
\hline Trivial Name (Structure) & Organism & Origin & Year & References \\
\hline \multirow{4}{*}{ 4-isothiocyanatoeudesm-11-ene (Eu20) } & Acanthella klethra & Pelorus Islands, Queensland, Australia & 1992 & {$[30]$} \\
\hline & Acanthella cavernosa & Heron Island, Great Barrier Reef, Australia & 2000 & [31] \\
\hline & Acanthella cavernosa & Mudjimba Island, Mooloolaba, Australia & 2007 & {$[32,58]$} \\
\hline & Axinyssa isabela & Isabel Island, Nayarit, Mexico & 2008 & [33] \\
\hline 4-formamidoeudesm-11-ene (Eu21) & Axinyssa ambrosia & $\begin{array}{c}\text { Santa Marta Bay, Caribbean Coast, } \\
\text { Colombia }\end{array}$ & 2002 & [26] \\
\hline stylostelline (Eu22) & Stylotella sp. & South East of New Caledonia & 1987 & [34] \\
\hline ent-stylotelline (Eu23) & Phyllidiella pustulosa & Hainan Island, South China Sea & 2004 & {$[35]$} \\
\hline \multirow{2}{*}{ 4-isothiocyanatoeudesm-11-ene (Eu24) } & Acanthella klethra & Pelorus Islands, Queensland, Australia & 1992 & [30] \\
\hline & $\begin{array}{c}\text { Acanthella sp. and Cadlina } \\
\text { luteomarginata }\end{array}$ & $\begin{array}{l}\text { Conehead Point, Rennell Sound, Graham } \\
\text { Island, British Columbia }\end{array}$ & 1993 & {$[23]$} \\
\hline axinisothiocyanate M (Eu25) & Axinyssa isabela & Isabel Island, Nayarit, Mexico & 2008 & [33] \\
\hline axinisothiocyanate N (Eu26) & Axinyssa isabela & Isabel Island, Nayarit, Mexico & 2008 & [33] \\
\hline 4-formamidoeudesm-7-ene (Eu27) & Axinyssa sp. & South China Sea & 2008 & [36] \\
\hline 4-formamidoeudesman-11-ol (Eu28) & Axinyssa sp. & South China Sea & 2008 & [36] \\
\hline halichonadin E (Eu29) & Halichondria sp. & Unten Port, Okinawa, Japan & 2008 & [37] \\
\hline halichonadin G (Eu30) & Halichondria sp. & Unten Port, Okinawa, Japan & 2011 & {$[38]$} \\
\hline halichonadin H (Eu31) & Halichondria sp. & Unten Port, Okinawa, Japan & 2011 & {$[38]$} \\
\hline halichonadin I (Eu32) & Halichondria sp. & Unten Port, Okinawa, Japan & 2011 & [38] \\
\hline halichonadin J (Eu33) & Halichondria sp. & Unten Port, Okinawa, Japan & 2011 & {$[38]$} \\
\hline
\end{tabular}


Table 1. Cont

\begin{tabular}{|c|c|c|c|c|}
\hline Trivial Name (Structure) & Organism & Origin & Year & References \\
\hline \multicolumn{5}{|c|}{ Cadinanes } \\
\hline \multirow{3}{*}{ (-)-10-isocyano-4-amorphene (Ca2) } & Halichondria sp. & North coast of $\mathrm{O}^{\prime}$ ahu, Hawaii & 1975 & {$[6,39,40]$} \\
\hline & Axinyssa & Gun Beach, Guam & 1989 & [43] \\
\hline & Phyllidia ocelata & Kamikoshiki-jima Island, Japan & 1996 & [42] \\
\hline \multirow{3}{*}{ (-)-10-isothiocyanato-4-amorphene (Ca3) } & Halichondria sp. & North coast of O'ahu, Hawaii & 1975 & {$[6,39,40]$} \\
\hline & Phyllidia pustulosa & Yakushima Island, Japan & 1996 & [42] \\
\hline & Phyllidiella pustulosa & Vietnam & 2010 & [27] \\
\hline (-)-10-isoformamido-4-amorphene (Ca4) & Halichondria sp. & North coast of $\mathrm{O}^{\prime}$ ahu, Hawaii & 1975 & {$[6,39,40]$} \\
\hline $\mathrm{R}=\mathrm{NC}(\mathrm{Ca} 5)$ & Axinella cannabina & Bay of Taranto, Porto Cesareo, Italy & 1986 & [44] \\
\hline $\mathrm{R}=\mathrm{NCS}(\mathrm{Ca}$ ) & Axinella cannabina & Bay of Taranto, Porto Cesareo, Italy & 1986 & {$[44]$} \\
\hline $\mathrm{R}=\mathrm{NHCHO}(\mathbf{C a} 7)$ & Axinella cannabina & Bay of Taranto, Porto Cesareo, Italy & 1986 & {$[44]$} \\
\hline$\left(3 S^{*}, 5 R^{*}, 6 R^{*}, 9 R^{*}\right)$-3-isocyano-1(10)-cadinene (Ca8) & Axinyssa aplysinoides & West of Malakal Harbor, Palau & 1995 & [46] \\
\hline halipanicine (Ca9) & Halochondria panacea & Okinawa, Japan & 1991 & [45] \\
\hline \multirow{2}{*}{$\begin{array}{c}\left(3 S^{*}, 5 R^{*}, 6 R^{*}, 9 R^{*}\right) \text {-3-formamido-1(10)-cadinene } \\
\text { (Ca10) }\end{array}$} & Axinyssa aplysinoides & West of Malakal Harbor, Palau & 1995 & [46] \\
\hline & Halichondria sp. & $\begin{array}{l}\text { PP Island, Andaman Sea, } \\
\text { Southern Thailand }\end{array}$ & 2011 & [59] \\
\hline $4 \alpha$-isocyano-9-amorphene (Ca11) & Phyllidia pustulosa & Hachijo-jima Island, Japan & 1991 & [47] \\
\hline \multirow{2}{*}{$10 \alpha$-isocyano-4-amorphene (Ca12) } & Acanthella cf. cavernosa & Hachijo-jima Island, Japan & 1992 & [19] \\
\hline & Phyllidia ocellata & Hachijo-jima Island, Japan & 1992 & [19] \\
\hline 10-isocyano-4-cadinene (Ca13) & Phyllidia pustulosa + varicosa & $\begin{array}{l}\text { Kamikoshiki-jima/Shimokoshiki Island, } \\
\text { Japan }\end{array}$ & 1996 & [42] \\
\hline
\end{tabular}


Table 1. Cont

\begin{tabular}{|c|c|c|c|c|}
\hline Trivial Name (Structure) & Organism & Origin & Year & References \\
\hline \multirow{3}{*}{ 10-isothiocyanate-4-cadinene (Ca14) } & Acanthella cavernosa & Heron Island, Great Barrier Reef, Australia & 2000 & {$[31]$} \\
\hline & Stylissa sp. & Iriomote Island, Okinawa, Japan & 2004 & {$[50]$} \\
\hline & Acanthella cavernosa & $\begin{array}{l}\text { Tani's Reef, Gneerings Reef, } \\
\text { Mooloolaba, Australia }\end{array}$ & 2007 & {$[32,58]$} \\
\hline \multirow{2}{*}{ R=NCS (Ca15) } & Acanthella pulcherrima & Weed Reef, Darwin, Australia & 1988 & {$[28]$} \\
\hline & Acanthella cavernosa & $\begin{array}{l}\text { Coral Gardens, Gneerings Reef, } \\
\text { Mooloolaba, Australia }\end{array}$ & 2007 & {$[32,58]$} \\
\hline \multirow{3}{*}{$\begin{array}{l}(1 R, 6 S, 7 S, 10 S)-10 \text {-isothiocyanato-4-amorphene } \\
\text { (Ca16) }\end{array}$} & Axinella fenestratus & Fiji & 1991 & [49] \\
\hline & Topsentia sp., Acanthella cavernosa & Thailand & 1991 & [49] \\
\hline & Acanthella cavernosa & $\begin{array}{l}\text { Tani's Reef, Gneerings Reef, } \\
\text { Mooloolaba, Australia }\end{array}$ & 2007 & {$[32,58]$} \\
\hline $\begin{array}{c}\left(1 R^{*}, 6 R^{*}, 7 S^{*}, 10 S^{*}\right) \text {-10-isothiocyanatocadin-4-ene } \\
\text { (Ca17) }\end{array}$ & Stylissa sp. & Coral reef, Iriomote Island, Okinawa, Japan & 2004 & {$[50]$} \\
\hline axinisothiocyanate K (Ca18) & Axinyssa & Gulf of California & 2008 & [51] \\
\hline \multirow{2}{*}{$\begin{array}{l}\left(1 R^{*}, 4 S^{*}, 6 R^{*}, 7 S^{*}\right) \text {-4-isothiocyanato-9-amorphene } \\
\text { (Ca19) }\end{array}$} & Axinella fenestratus & Fiji & 1991 & [49] \\
\hline & Topsentia sp., Acanthella cavernosa & Thailand & 1991 & [49] \\
\hline \multirow{2}{*}{$\left(1 S^{*}, 4 S^{*}, 6 S^{*}, 7 R^{*}\right)$-4-thiocyanato-9-cadinene (Ca20) } & Trachyopsis aplysinoides & Palau & 1989 & {$[52]$} \\
\hline & Phyllidia pustulosa & Katsuura, Kii Penisula, Japan & 1998 & [53] \\
\hline $\begin{array}{c}\left(1 S^{*}, 4 S^{*}, 7 R^{*}, 10 S^{*}\right) \text {-10-isocyano-5-cadinen-4-ol } \\
\text { (Ca21) }\end{array}$ & Phyllidia pustulosa & Katsuura, Kii Penisula, Japan & 1998 & {$[53]$} \\
\hline \multirow{2}{*}{ 10-isothiocyanatoamorph-5-en-4-ol (Ca22) } & Axinella fenestratus & Fiji & 1991 & [49] \\
\hline & Topsentia sp., Acanthella cavernosa & Thailand & 1991 & [49] \\
\hline
\end{tabular}


Table 1. Cont.

\begin{tabular}{|c|c|c|c|c|}
\hline Trivial Name (Structure) & Organism & Origin & Year & References \\
\hline axinisothiocyanate J (Ca23) & Axinyssa & Gulf of California & 2008 & [51] \\
\hline axinisothiocyanate A (Ca24) & Axinyssa & Gulf of California & 2008 & [51] \\
\hline axinisothiocyanate B (Ca25) & Axinyssa & Gulf of California & 2008 & [51] \\
\hline axinisothiocyanate C (Ca26) & Axinyssa & Gulf of California & 2008 & [51] \\
\hline axinisothiocyanate D (Ca27) & Axinyssa & Gulf of California & 2008 & {$[51]$} \\
\hline axinisothiocyanate E (Ca28) & Axinyssa & Gulf of California & 2008 & {$[51]$} \\
\hline axinisothiocyanate F (Ca29) & Axinyssa & Gulf of California & 2008 & [51] \\
\hline axinisothiocyanate G (Ca30) & Axinyssa & Gulf of California & 2008 & [51] \\
\hline axinisothiocyanate $\mathrm{H}$ (Ca31) & Axinyssa & Gulf of California & 2008 & [51] \\
\hline axinisothiocyanate I (Ca32) & Axinyssa & Gulf of California & 2008 & [51] \\
\hline axinisothiocyanate L (Ca33) & Axinyssa & Gulf of California & 2008 & [51] \\
\hline \multirow[t]{2}{*}{ Axiplyn C (Ca34) } & Axinyssa aplysinoides & Misali Island, Tanzania & 2008 & [54] \\
\hline & Spiroas & & & \\
\hline \multirow{11}{*}{ (+)-axisonitril-3 (Sp2) } & Axinella cannabina & Bay of Taranto, Italy & 1976 & [55] \\
\hline & Acanthella acuta & Mediterranean sea & 1987 & [57] \\
\hline & Topsentia sp. & Thailand & 1991 & [49] \\
\hline & Acanthella klethra & Pelorus Islands, Queensland, Australia & 1992 & [30] \\
\hline & Axinyssa aplysinoides & Mutok Harbor, Pohnpei & 1992 & [69] \\
\hline & Acanthella cf. cavernosa & Hachijo-jima Island, Japan & 1992 & [19] \\
\hline & Phyllidia ocellata & Hachijo-jima Island, Japan & 1992 & [19] \\
\hline & Phyllidia pustulosa & $\begin{array}{l}\text { Yakushima/Kuchinoerabu-jima/ } \\
\text { Tenegashima Islands, Japan }\end{array}$ & 1996 & {$[42]$} \\
\hline & Acanthella cavernosa & $\begin{array}{c}\text { Tani's Reef, Gneerings Reef, } \\
\text { Mooloolaba, Australia }\end{array}$ & 2007 & {$[32,58]$} \\
\hline & Acanthella sp. & Yalong Bay, Hainan Province, China & 2009 & [103] \\
\hline & Phyllidia ocellata & Mudjimba Island, Mooloolaba, Australia & 2015 & [94] \\
\hline
\end{tabular}


Table 1. Cont.

\begin{tabular}{|c|c|c|c|c|}
\hline Trivial Name (Structure) & Organism & Origin & Year & References \\
\hline \multirow{6}{*}{ (+)-axisothiocyanate-3 (Sp3) } & Axinella cannabina & Bay of Taranto, Italy & 1976 & [55] \\
\hline & Acanthella klethra & Pelorus Islands, Queensland, Australia & 1992 & {$[30]$} \\
\hline & Acanthella cf. cavernosa & Hachijo-jima Island, Japan & 1992 & [19] \\
\hline & Phyllidia ocellata & Hachijo-jima Island, Japan & 1992 & [19] \\
\hline & Acanthella cavernosa & Hachijo-jima Island, Japan & 1996 & [20] \\
\hline & Acanthella cavernosa & $\begin{array}{l}\text { Tani's Reef, Gneerings Reef, } \\
\text { Mooloolaba, Australia }\end{array}$ & 2007 & {$[32,58]$} \\
\hline \multirow{3}{*}{$(-)$-axamide-3 (Sp4) } & Axinella cannabina & Bay of Taranto, Italy & 1976 & [55] \\
\hline & Acanthella cf. cavernosa & Hachijo-jima Island, Japan & 1992 & [19] \\
\hline & Phyllidia ocellata & Hachijo-jima Island, Japan & 1992 & [19] \\
\hline axisocyanate-3 (Sp5) & Acanthella cavernosa & Mudjimba Island, Mooloolaba, Australia & 2007 & {$[32,58]$} \\
\hline (-)-axisonitrile-3 (Sp6) & Halichondria sp. & $\begin{array}{l}\text { PP Island, Andaman Sea, Southern } \\
\text { Thailand }\end{array}$ & 2011 & [59] \\
\hline \multirow{3}{*}{ (+)-axamide (Sp7) } & Axinella cannabina & Bay of Taranto, Italy & 1976 & [55] \\
\hline & Acanthella cavernosa & Hachijo-jima Island, Japan & 1996 & [20] \\
\hline & Halichondria sp. & $\begin{array}{l}\text { PP Island, Andaman Sea, } \\
\text { Southern Thailand }\end{array}$ & 2011 & [59] \\
\hline \multirow{2}{*}{ 10-epi-axisonitrile-3 (Sp8) } & Phyllidia pustulosa & $\begin{array}{l}\text { Yakushima/Kuchinoerabu-jima Islands, } \\
\text { Japan }\end{array}$ & 1996 & [42] \\
\hline & Geodia exigua & Oshima, Kagoshima Prefecture, Japan & 2003 & {$[60]$} \\
\hline exiguamide (Sp9) & Geodia exigua & Oshima, Kagoshima Prefecture, Japan & 2003 & {$[60]$} \\
\hline exicarbamate (Sp10) & Geodia exigua & Oshima, Kagoshima Prefecture, Japan & 2003 & {$[60]$} \\
\hline exigurin (Sp11) & Geodia exigua & Oshima, Kagoshima Prefecture, Japan & 2003 & {$[60]$} \\
\hline
\end{tabular}


Table 1. Cont.

\begin{tabular}{|c|c|c|c|c|}
\hline Trivial Name (Structure) & Organism & Origin & Year & References \\
\hline 3-Oxoaxisonitrile-3 (Sp12) & Acanthella sp. & South China Sea & 2006 & {$[61]$} \\
\hline $\mathrm{R}=\mathrm{NC}(\mathrm{Sp} 13)$ & Acanthella acuta & Bay of Naples, Italy & 1987 & {$[62]$} \\
\hline $\mathrm{R}=\mathrm{NCS}(\mathrm{Sp} 14)$ & Acanthella acuta & Bay of Naples, Italy & 1987 & [62] \\
\hline \multirow{3}{*}{$(2 R, 5 R, 10 S)$-2-isothiocyanato-6-axene (Sp15) } & Trachyopsis aplysinoides & Palau & 1989 & [52] \\
\hline & Axinyssa aplysinoides & Palau & 1992 & [69] \\
\hline & Amorphinopsis foetida & Madang region, Papua New Guinea & 2006 & {$[63]$} \\
\hline \multirow{3}{*}{$(2 R, 5 R, 10 S)$-2-formamido-6-axene (Sp16) } & Trachyopsis aplysinoides & Palau & 1989 & {$[52]$} \\
\hline & Axinyssa aplysinoides & Palau & 1992 & [69] \\
\hline & Axinyssa aplysinoides & Mele Bay, Vanuatu & 2006 & [63] \\
\hline $\mathrm{R}=\mathrm{NHCHO}(\mathrm{Sp} \mathbf{1 7})$ & Amorphinopsis foetida & Madang region, Papua New Guinea & 2006 & [63] \\
\hline N-Phenethyl-2-formamido-6-axene (Sp18) & $\begin{array}{l}\text { Amorphinopsis foetida and } \\
\text { Axinyssa aplysinoides }\end{array}$ & $\begin{array}{c}\text { Madang region, Papua New guinea and } \\
\text { Mele Bay, Vanuatu }\end{array}$ & 2006 & [63] \\
\hline N-Phenethyl-2-formamido-6-axene (Sp19) & $\begin{array}{l}\text { Amorphinopsis foetida and } \\
\text { Axinyssa aplysinoides }\end{array}$ & $\begin{array}{l}\text { Madang region, Papua New guinea and } \\
\text { Mele Bay, Vanuatu }\end{array}$ & 2006 & [63] \\
\hline \multicolumn{5}{|c|}{ Aromadendranes } \\
\hline \multirow{6}{*}{ axisonitrile-2 (Ar2) } & Axinella cannabina & Bay of Taranto, Italy & 1974 & [4] \\
\hline & Acanthella cannabina & Taranto, near Porto Cesareo, Italy & 1986 & {$[44]$} \\
\hline & Phyllidia pustulosa & Hachijo-jima Island, Japan & 1991 & [47] \\
\hline & Acanthella cf. cavernosa & Hachijo-jima Island, Japan & 1992 & [19] \\
\hline & Acanthella cavernosa & Hachiji-jima Island, Japan & 1996 & [20] \\
\hline & Phyllidia ocellata & Mudjimba Island, Mooloolaba, Australia & 2015 & [94] \\
\hline
\end{tabular}


Table 1. Cont.

\begin{tabular}{|c|c|c|c|c|}
\hline Trivial Name (Structure) & Organism & Origin & Year & References \\
\hline \multirow{3}{*}{ axamide-2 (Ar3) } & Axinella cannabina & Bay of Taranto, Italy & 1974 & [4] \\
\hline & Hexabrandies sanguinens & South China Sea & 2007 & [68] \\
\hline & Halichondria sp. & $\begin{array}{l}\text { PP Island, Andaman Sea, } \\
\text { Southern Thailand }\end{array}$ & 2011 & [59] \\
\hline \multirow{6}{*}{ axisothiocyanate-2/epipolasin B (Ar4) } & Axinella cannabina & Bay of Taranto, Italy & 1974 & [4] \\
\hline & Epipolasis kushimotoensis & & 1985 & {$[64]$} \\
\hline & Axinyssa aplysinoides & Ant Atoll, Pohnpei & 1992 & [69] \\
\hline & Acanthella cavernosa & Hachijo-jima Island, Japan & 1996 & [20] \\
\hline & Axinyssa sp. & Tsutsumi Island, Fukuoka prefecture, Japan & 2002 & [165] \\
\hline & Acanthella cavernosa & $\begin{array}{l}\text { Tani's Reef, Gneerings Reef, } \\
\text { Mooloolaba, Australia }\end{array}$ & 2007 & {$[32,58]$} \\
\hline epipolasinthiourea-B (Ar5) & Epipolasis kushimotoensis & & 1985 & {$[64]$} \\
\hline $10 \alpha$-isocyanoalloaromadendrane (Ar6) & Acanthella cannabina & Taranto, near Porto Cesareo, Italy & 1987 & [25] \\
\hline $10 \alpha$-formamidoalloaromadendrane (Ar7) & Acanthella cannabina & Taranto, near Porto Cesareo, Italy & 1987 & {$[25]$} \\
\hline \multirow{2}{*}{$10 \alpha$-isothiocyanatoalloaromadendrane (Ar8) } & Acanthella cannabina & Taranto, near Porto Cesareo, Italy & 1987 & [25] \\
\hline & Acanthella cavernosa & $\begin{array}{l}\text { Tani's Reef, Gneerings Reef, } \\
\text { Mooloolaba, Australia }\end{array}$ & 2007 & {$[32,58]$} \\
\hline \multirow{3}{*}{$\begin{array}{l}(1 R, 4 S, 5 S, 6 R, 7 S, 10 R)-(+)- \\
\text { isothiocyanatoalloaromadendrane (Ar9) }\end{array}$} & Acanthella cavernosa & Hachijo-jima Island, Japan & 1996 & {$[20]$} \\
\hline & Acanthella sp. & Yalong Bay, Hainan Province, China & 2009 & [103] \\
\hline & Phyllidiella pustulosa & Vietnam & 2010 & [27] \\
\hline Halochonadin F (Ar11) & Halichondria sp. & Unten Port, Okinawa, Japan & 2008 & {$[66]$} \\
\hline $\mathrm{R}=\mathrm{NCS}($ Ar12) & Axinyssa aplysinoides & Ant Atoll, Pohnpei & 1992 & [69] \\
\hline
\end{tabular}


Table 1. Cont.

\begin{tabular}{|c|c|c|c|c|}
\hline Trivial Name (Structure) & Organism & Origin & Year & References \\
\hline \multirow{5}{*}{$\mathrm{R}=\mathrm{NC}(\mathrm{Ar13})$} & Acanthella acuta & Bay of Naples, Italy & 1987 & {$[62]$} \\
\hline & Acanthella acuta & Banyuls, France & 1988 & [67] \\
\hline & Acanthella cavernosa & $\begin{array}{c}\text { Tani's Reef, Gneerings Reef, } \\
\text { Mooloolaba, Australia }\end{array}$ & 2007 & {$[32,58]$} \\
\hline & Phyllidiella pustulosa & Vietnam & 2010 & [27] \\
\hline & Phyllidia ocellata & Mudjimba Island, Mooloolaba, Australia & 2015 & [94] \\
\hline \multirow{4}{*}{$\mathrm{R}=\mathrm{NCS}$ (Ar14) } & Acanthella acuta & Bay of Naples, Italy & 1987 & [62] \\
\hline & Acanthella acuta & Banyuls, France & 1988 & [67] \\
\hline & Acanthella cavernosa & $\begin{array}{l}\text { Tani's Reef, Gneerings Reef, } \\
\text { Mooloolaba, Australia }\end{array}$ & 2007 & {$[32,58]$} \\
\hline & Phyllidiella pustulosa & Vietnam & 2010 & [27] \\
\hline \multirow[t]{2}{*}{$\mathrm{R}=\mathrm{NCO}(\mathrm{Ar} 15)$} & Acanthella cavernosa & $\begin{array}{l}\text { Coral gardens, Gneerings reef, } \\
\text { Mooloolba, Australia }\end{array}$ & 2007 & {$[32,58]$} \\
\hline & Acanthella acuta & Banyuls, France & 1988 & [67] \\
\hline R=NHCHO (Ar16) & Hexabrandies sanguinens & South China Sea & 2007 & [68] \\
\hline \multicolumn{5}{|c|}{ Epimaalianes } \\
\hline \multirow{2}{*}{$\mathrm{R}=\mathrm{NC}(\mathrm{Ep} 2)$} & Cadlina luteomarginata & San Diego, California & 1982 & [70] \\
\hline & $\begin{array}{l}\text { Acanthella sp. and } \\
\text { Cadlina luteomarginata }\end{array}$ & $\begin{array}{l}\text { Conehead Point, Rennell Sound, } \\
\text { Graham Island, British Columbia }\end{array}$ & 1993 & {$[23]$} \\
\hline
\end{tabular}


Table 1. Cont.

\begin{tabular}{|c|c|c|c|c|}
\hline Trivial Name (Structure) & Organism & Origin & Year & References \\
\hline \multirow{5}{*}{ (-)-epipolasin A (Ep3) } & Cadlina luteomarginata & San Diego, California & 1982 & [70] \\
\hline & Acanthella pulcherrima & Weed Reef, Darwin, Australia & 1988 & {$[28]$} \\
\hline & Acanthella sp. & $\begin{array}{l}\text { Conehead Point, Rennell Sound, } \\
\text { Graham Island, British Columbia }\end{array}$ & 1993 & {$[23]$} \\
\hline & Axinyssa sp. nov. & Great Barrier Reef & 1997 & {$[71]$} \\
\hline & Axinyssa sp. & Tsutsumi Island, Fukuoka prefecture, Japan & 2003 & [165] \\
\hline $\mathrm{R}=\mathrm{NHCHO}(\mathbf{E p} 4)$ & $\begin{array}{l}\text { Acanthella sp. and } \\
\text { Cadlina luteomarginata }\end{array}$ & $\begin{array}{l}\text { Conehead Point, Rennell Sound, } \\
\text { Graham Island, British Columbia }\end{array}$ & 1993 & {$[23]$} \\
\hline \multirow{2}{*}{ (+)-epipolasin A (Ep5) } & Epipolasis kushimotoensis & & 1985 & [64] \\
\hline & Axinyssa aplysinoides & Ant Atoll, Pohnpei & 1992 & [69] \\
\hline $\mathrm{R}=\mathrm{NHCSNHCH}_{2} \mathrm{CH}_{2} \mathrm{Ph}$ (Ep6) & Epipolasis kushimotoensis & & 1985 & [64] \\
\hline $\mathrm{R}=\mathrm{NC}(\mathrm{Ep} 7)$ & Axinella cannabina & Bay of Taranto, Italy & 1985 & {$[72]$} \\
\hline $\mathrm{R}=\mathrm{NCS}(\mathrm{Ep} 8)$ & Axinella cannabina & Bay of Taranto, Italy & 1985 & {$[72]$} \\
\hline R=NHCHO (Ep9) & Axinella cannabina & Bay of Taranto, Italy & 1985 & [72] \\
\hline \multicolumn{5}{|c|}{ Pupukeananes } \\
\hline \multirow{4}{*}{ 9-isocyanopupukeanane (Pu2) } & Phyllidia varicosa and Cyocalypta sp. & Pupukea, north shore of $\mathrm{O}^{\prime}$ ahu, Hawaii & 1975 & [73] \\
\hline & Phyllidia varicosa Lamarck 1801 & Pupukea, north shore of $\mathrm{O}^{\prime}$ ahu, Hawaii & 1979 & [77] \\
\hline & Phyllidia bourguini & Hachijo-jima Island, Japan & 1990 & [75] \\
\hline & Phyllidia pustulosa & Hachijo-jima Island, Japan & 1991 & {$[47]$} \\
\hline \multirow{2}{*}{ 9-epi-isocyanopupukeanane (Pu3) } & Phyllidia bourguini & Hachijo-jima Island, Japan & 1990 & [75] \\
\hline & Phyllidia pustulosa & Hachijo-jima Island, Japan & 1991 & [47] \\
\hline
\end{tabular}


Table 1. Cont.

\begin{tabular}{|c|c|c|c|c|}
\hline Trivial Name (Structure) & Organism & Origin & Year & References \\
\hline 9-isothiocyanatopupukeanane (Pu4) & Axinyssa sp. nov. & Great Barrier Reef & 1997 & {$[71]$} \\
\hline \multirow{2}{*}{ 9-thiocyanatopupukeanane (Pu5) } & Phyllidia varicosa Axinyssa aculeata & Pramuka Island, Indonesia & 2003 & [76] \\
\hline & Phyllidiella pustulosa & Vietnam & 2010 & [27] \\
\hline \multirow{2}{*}{ 9-epi-thiocyanatopupukeanane (Pu6) } & Phyllidia varicosa Axinyssa aculeata & Pramuka Island, Indonesia & 2003 & [76] \\
\hline & Phyllidiella pustulosa & Vietnam & 2010 & [27] \\
\hline 2-isocyanopupukeanane (Pu7) & Phyllidia varicosa Lamarck 1801 & Pupukea, north shore of $\mathrm{O}^{\prime}$ ahu, Hawaii & 1979 & [77] \\
\hline 2-thiocyanatopupukeanane (Pu8) & Axinyssa aplysinoides & Palau & 1992 & [69] \\
\hline 2-formamidopupukeanane (Pu9) & Phyllidia coelestis Bergh & Koh-Ha Islets, Thailand & 2013 & [78] \\
\hline 5-isothiocyanatopupukeanane (Pu10) & Axinyssa & Gun Beach, Guam & 1989 & [43] \\
\hline 9-isocyanoneopupukeanane (Pu11) & Ciocalypta sp. & O'ahu, Hawaii & 1989 & [155] \\
\hline \multirow{3}{*}{ 2-thiocyanatoneopupukeanane (Pu12) } & Phycopsis terpnis & Okinawa, Japan and Pohnpei & 1991 & [80] \\
\hline & Axinyssa aplysinoides & Mutok Harbor, Pohnpei & 1992 & [69] \\
\hline & Phyllidia pustulosa & Kuchinoerabu/Tanegoshima Island, Japan & 1996 & [42] \\
\hline \multirow{2}{*}{ 4-thiocyanatoneopupukeanane (Pu13) } & Phycopsis terpnis & Okinawa, Japan and Pohnpei & 1991 & [80] \\
\hline & Phyllidia pustulosa & Tanegoshima Island, Japan & 1996 & [42] \\
\hline 2-isocyanoallopupukeanane (Pu14) & Phyllidia pustulosa & Hachijo-jima Island, Japan & 1991 & [47] \\
\hline 1-formamido-10(1 $\rightarrow$ 2)-abeopupukeanane (Pu15) & Phyllidia coelestis Bergh & Koh-Ha Islets, Thailand & 2013 & [78] \\
\hline
\end{tabular}


Table 1. Cont

\begin{tabular}{|c|c|c|c|c|}
\hline Trivial Name (Structure) & Organism & Origin & Year & References \\
\hline \multicolumn{5}{|c|}{ Bisabolanes } \\
\hline \multirow{5}{*}{ 3-isocyanotheonellin (Bi2) } & Phyllidia sp. & Colombo, Sri Lanka & 1986 & [74] \\
\hline & Phyllidia pustulosa & Hachijo-jima Island, Japan & 1991 & [47] \\
\hline & Phyllidiella pustulosa & Hainan Island, South China Sea & 2004 & [35] \\
\hline & Lipastrotethya ana & Lingshui Bay, Hainan & 2007 & [166] \\
\hline & Raphoxya sp. & Blue Hole, Guam & 2012 & [82] \\
\hline \multirow{5}{*}{ 3-isothiocyanatotheonellin (Bi3) } & Theonella cf. swinhoei & Okinawa & 1984 & [81] \\
\hline & Phyllidia pustulosa & Tanegoshima Island, Japan & 1996 & [42] \\
\hline & Axinyssa & Micronesia & 1999 & {$[90]$} \\
\hline & Lipastrotethya ana & Lingshui Bay, Hainan & 2007 & [91] \\
\hline & Raphoxya sp. & Blue Hole, Guam & 2012 & [82] \\
\hline \multirow[b]{2}{*}{ 3-formamidotheonellin (Bi4) } & Theonella cf. swinhoei & Okinawa & 1984 & [81] \\
\hline & Axinyssa sp. & Inner coral reef, Andaman Sea, Thailand & 2014 & [92] \\
\hline 3-isocyanatotheonellin (Bi5) & Raphoxya sp. & Blue Hole, Guam & 2012 & [82] \\
\hline \multirow{3}{*}{ 7-isocyano-7,8-dihydro- $\alpha$-bisabolene (Bi6) } & Ciocalypta sp. & Pupukea, O'ahu, Hawaii & 1986 & [74] \\
\hline & Phyllidia pustulosa & Hachijo-jima Island, Japan & 1991 & [47] \\
\hline & Acanthella cavernosa & $\begin{array}{l}\text { Tani's Reef, Gneerings Reef, } \\
\text { Mooloolaba, Australia }\end{array}$ & 2007 & {$[32,58]$} \\
\hline
\end{tabular}


Table 1. Cont.

\begin{tabular}{|c|c|c|c|c|}
\hline Trivial Name (Structure) & Organism & Origin & Year & References \\
\hline \multirow{5}{*}{ 7-isothiocyanato-7,8-dihydro- $\alpha$-bisabolene (Bi7) } & Halichondria sp. & Ponape, Marshall Islands & 1986 & [83] \\
\hline & Phyllidia pustulosa & $\begin{array}{l}\text { Negros Island, Cebu Island, San Sebastian, } \\
\text { Cebu, Philippines }\end{array}$ & 1991 & [86] \\
\hline & Acanthella cf. cavernosa & Hachijo-jima Island, Japan & 1992 & [19] \\
\hline & Phyllidia pustulosa & Hachijo-jima Island, Japan & 1992 & [19] \\
\hline & Acanthella cavernosa & $\begin{array}{l}\text { Tani's Reef, Gneerings Reef, } \\
\text { Mooloolaba, Australia }\end{array}$ & 2007 & {$[32,58]$} \\
\hline$N, N^{\prime}$-Bis(6R,7S)-7,8-dihydro- $\alpha$-bisabolane (Bi8) & Halichondria sp. & Ponape, Marshall Islands & 1986 & [83] \\
\hline 7-formamido-7,8-dihydro- $\alpha$-bisabolene (Bi9) & Axinyssa sp. & Sanya, Hainan Province, China & 2008 & [84] \\
\hline 7-isocyano-7,8-dihydro- $\alpha$-bisabolene (Bi10) & Ciocalypta sp. & Pupukea, O'ahu, Hawaii & 1986 & [74] \\
\hline 7-isocyanato-7,8-dihydro- $\alpha$-bisabolene (Bi11) & Ciocalypta sp. & Pupukea, O'ahu, Hawaii & 1986 & [74] \\
\hline $\mathrm{R}=\mathrm{NC}(\mathrm{Bi12})$ & Phyllidiella pustulosa & Hainan Island, South China Sea & 2004 & [35] \\
\hline (E)-4-isocyanobisabolane-7,10-diene (Bi13) & Axinyssa & Okinawa & 2002 & {$[85]$} \\
\hline 3-isocyanobisabolane-8,10-diene (Bi14) & Phyllidia pustulosa & $\begin{array}{l}\text { Negros Island, Cebu Island, San Sebastian, } \\
\text { Cebu, Philippines }\end{array}$ & 1991 & {$[86]$} \\
\hline 3-formamidobisabolene-8,10-diene (Bi15) & Halichondria cf. lengenfeldi & Palau & 1991 & [86] \\
\hline axinythiocyanate A (Bi16) & Axinyssa isabela & Isabel Island, Nayarit, Mexico & 2008 & [33] \\
\hline 3-isocyano-7,8-epoxy- $\alpha$-bisabolane (Bi17) & Axinyssa sp. & Hainan & 2010 & [87] \\
\hline \multirow{2}{*}{ 3-formamido-7,8-epoxy- $\alpha$-bisabolane (Bi18) } & Axinyssa sp. & Hainan & 2010 & [87] \\
\hline & Axinyssa sp. & Inner coral reef, Andaman Sea, Thailand & 2014 & [92] \\
\hline axinysaline B (Bi19) & Axinyssa sp. & Formosa & 2014 & {$[88]$} \\
\hline axinysaline A (Bi20) & Axinyssa sp. & Formosa & 2014 & [88] \\
\hline
\end{tabular}


Table 1. Cont.

\begin{tabular}{|c|c|c|c|c|}
\hline Trivial Name (Structure) & Organism & Origin & Year & References \\
\hline $7 \alpha, 8 \alpha$-epoxy theonellin isothiocyanate (Bi21) & Phycopsis sp. & $\begin{array}{l}\text { Mandapam Coast, Gulf of Mannar, } \\
\text { Tamilnadu, India }\end{array}$ & 2009 & [89] \\
\hline 3-formamidobisabolane-14(7),9-dien-8-ol (Bi22) & Axinyssa & Micronesia & 1999 & {$[90]$} \\
\hline 3-formamidobisabolane-14(7),9-dien-8-one (Bi23) & Axinyssa & Micronesia & 1999 & {$[90]$} \\
\hline 11-ethoxy-3-formamidotheonellin (Bi24) & Axinyssa aff. variabilis & Lingshui Bay, Hainan & 2007 & [91] \\
\hline 7-ethoxy-3-formamidobisabolane-8,10-diene (Bi25) & Axinyssa aff. variabilis & Lingshui Bay, Hainan & 2007 & [91] \\
\hline axinyssine C (Bi26) & Axinyssa sp. & Inner coral reef, Andaman Sea, Thailand & 2014 & [92] \\
\hline axinyssine D (Bi27) & Axinyssa sp. & Inner coral reef, Andaman Sea, Thailand & 2014 & [92] \\
\hline axinyssine E (Bi28) & Axinyssa sp. & Inner coral reef, Andaman Sea, Thailand & 2014 & [92] \\
\hline axinyssine $F(\mathbf{B i 2 9})$ & Axinyssa sp. & Inner coral reef, Andaman Sea, Thailand & 2014 & [92] \\
\hline axinyssine G (Bi30) & Axinyssa sp. & Inner coral reef, Andaman Sea, Thailand & 2014 & {$[92]$} \\
\hline axinyssine $\mathrm{H}(\mathbf{B i 3 1})$ & Axinyssa sp. & Inner coral reef, Andaman Sea, Thailand & 2014 & [92] \\
\hline axinyssine I (Bi32) & Axinyssa sp. & Inner coral reef, Andaman Sea, Thailand & 2014 & [92] \\
\hline axinyssine J (Bi33) & Axinyssa sp. & Inner coral reef, Andaman Sea, Thailand & 2014 & [92] \\
\hline axinyssine K (Bi34) & Axinyssa sp. & Inner coral reef, Andaman Sea, Thailand & 2014 & [92] \\
\hline axinyssine L (Bi35) & Axinyssa sp. & Inner coral reef, Andaman Sea, Thailand & 2014 & [92] \\
\hline \multirow{2}{*}{$\begin{array}{l}\text { 3-formamido-8-methoxybisabolan-9-en-10-ol } \\
\text { (Bi36) }\end{array}$} & Axinyssa & Micronesia & 1999 & [90] \\
\hline & Axinyssa sp. & Inner coral reef, Andaman Sea, Thailand & 2014 & [92] \\
\hline
\end{tabular}


Table 1. Cont

\begin{tabular}{|c|c|c|c|c|}
\hline Trivial Name (Structure) & Organism & Origin & Year & References \\
\hline \multicolumn{5}{|c|}{ Guaianes } \\
\hline Guai-6-ene isocyanide (Gu2) & Not identified & Wakayama Prefecture, Japan & 1988 & [93] \\
\hline \multirow{2}{*}{ Guai-6-ene isothiocyanide (Gu3) } & Not identified & Wakayama Prefecture, Japan & 1988 & [93] \\
\hline & Acanthella cavernosa & $\begin{array}{l}\text { Tani's Reef, Gneerings Reef, } \\
\text { Mooloolaba, Australia }\end{array}$ & 2007 & {$[32,58]$} \\
\hline Guai-6-ene formamide (Gu4) & Not identified & Wakayama Prefecture, Japan & 1988 & [93] \\
\hline \multirow{2}{*}{$\begin{array}{r}\left(1 S^{*}, 4 S^{*}, 5 R^{*}, 10 S^{*}\right) \text {-10-Isothiocyanatoguaia-6-ene } \\
(\mathbf{G u 5})\end{array}$} & Trachyopsis aplysinoides & Palau & 1989 & [52] \\
\hline & Axinyssa aplysinoides & Palau & 1992 & [69] \\
\hline$\left(1 S^{*}, 4 S^{*}, 5 R^{*}, 10 S^{*}\right)$-10-Isocyanoguaia-6-ene (Gu6) & Phyllidiella pustulosa & Hainan Island, South China Sea & 2004 & [35] \\
\hline $\mathrm{R}=\mathrm{NC}(\mathrm{Gu} 7)$ & Phyllidia ocellata & Mudjimba Island, Mooloolaba, Australia & 2015 & [94] \\
\hline $0 \mathrm{R}=\mathrm{NCS}(\mathrm{Gu} 8)$ & Axinyssa sp. & Sanya Island, Hainan, China & 2008 & [84] \\
\hline $\mathrm{R}=\mathrm{NC}(\mathrm{Gu} \mathbf{9})$ & Acanthella acuta & Bay of Naples, Italy & 1987 & [62] \\
\hline R=NCS (Gu10) & Acanthella acuta & Bay of Naples, Italy & 1987 & [62] \\
\hline \multicolumn{5}{|c|}{ Further sesquiterpenoids } \\
\hline 2-isocyanotrachyopsane (Fu1) & Phyllidia varicosa & Shimokoshiki Island, Japan & 1996 & {$[42]$} \\
\hline \multirow{2}{*}{ 2-isothiocyanatotrachyopsane (Fu2) } & Trachyopsis aplysinoides & Palau & 1989 & {$[52]$} \\
\hline & Axinyssa aplysinoides & Palau & 1992 & [69] \\
\hline 2-(formylamino)trachyopsane (Fu3) & Axinyssa aplysinoides & Malakal Harbor, Palau & 1997 & [95] \\
\hline$N$-phenethyl- $N^{\prime}$-2-trachyopsane (Fu4) & Axinyssa aplysinoides & Malakal Harbor, Palau & 1997 & [95] \\
\hline $4 \alpha$-isocyanogorgon-11-ene (Fu5) & $\begin{array}{l}\text { Phyllidia varicosa and } \\
\text { Phyllidia pustulosa }\end{array}$ & $\begin{array}{c}\text { Negros Island, Cebu Island, San Sebastian, } \\
\text { Cebu, Philippines }\end{array}$ & 1991 & [86] \\
\hline
\end{tabular}


Table 1. Cont

\begin{tabular}{|c|c|c|c|c|}
\hline Trivial Name (Structure) & Organism & Origin & Year & References \\
\hline $4 \alpha$-isothiocyanatogorgon-11-ene (Fu6) & Phyllidia pustulosa & $\begin{array}{c}\text { Negros Island, Cebu Island, San Sebastian, } \\
\text { Cebu, Philippines }\end{array}$ & 1991 & {$[86]$} \\
\hline $4 \alpha$-formamidogorgon-11-ene (Fu7) & $\begin{array}{l}\text { Phyllidia varicosa and } \\
\text { Phyllidia pustulosa }\end{array}$ & $\begin{array}{c}\text { Negros Island, Cebu Island, San Sebastian, } \\
\text { Cebu, Philippines }\end{array}$ & 1991 & {$[86]$} \\
\hline $\begin{array}{c}(-)-(1 S, 2 R, 5 R, 8 R)-1 \text {-isothiocyanatoepicaryolane } \\
(\mathbf{F u} 8)\end{array}$ & Phyllidia ocellata & Mudjimba Island, Mooloolaba, Australia & 2015 & [94] \\
\hline $\begin{array}{c}\left(1 S^{*}, 2 R^{*}, 5 S^{*}, 6 S^{*}, 7 R^{*}, 8 S^{*}\right)-13 \text {-isothiocyanatocubebane } \\
(\mathbf{F u} \mathbf{9})\end{array}$ & Axinyssa aplysinoides & Ant Atoll, Pohnpei & 1992 & [69] \\
\hline $\begin{array}{c}\left(1 S^{*}, 2 S^{*}, 5 S^{*}, 6 S^{*}, 7 R^{*}, 8 S^{*}\right)-13 \text {-isocyanocubebane } \\
(\mathbf{F u 1 0})\end{array}$ & Phyllidia ocellata & Mudjimba Island, Mooloolaba, Australia & 2015 & [94] \\
\hline $\begin{array}{c}\left(1 S^{*}, 2 S^{*}, 5 S^{*}, 6 S^{*}, 7 R^{*}, 8 S^{*}\right) \text {-13-isothiocyanatocubebane } \\
(\text { Fu11) }\end{array}$ & Stylissa sp. & Iriomote Island, Okinawa, Japan & 2004 & {$[50]$} \\
\hline$(-)-(1 S, 5 S, 8 R)$-2-isocyanoclovene (Fu12) & Phyllidia ocellata & Mudjimba Island, Mooloolaba, Australia & 2015 & [94] \\
\hline$(-)-(1 S, 2 R, 5 S, 8 R)-2$-isocyanoclovane (Fu13) & Phyllidia ocellata & Mudjimba Island, Mooloolaba, Australia & 2015 & [94] \\
\hline axiplyn A (Fu14) & Axinyssa aplysinoides & Misali Island, Tanzania & 2008 & {$[54]$} \\
\hline axiplyn B (Fu15) & Axinyssa aplysinoides & Misali Island, Tanzania & 2008 & {$[54]$} \\
\hline axiplyn D (Fu16) & Axinyssa aplysinoides & Misali Island, Tanzania & 2008 & {$[54]$} \\
\hline axiplyn E (Fu17) & Axinyssa aplysinoides & Misali Island, Tanzania & 2008 & {$[54]$} \\
\hline
\end{tabular}


Table 1. Cont

\begin{tabular}{|c|c|c|c|c|}
\hline Trivial Name (Structure) & Organism & Origin & Year & References \\
\hline \multicolumn{5}{|c|}{ Diterpenoids } \\
\hline \multicolumn{5}{|c|}{ Acyclic } \\
\hline $\mathrm{R}=\mathrm{NC}(\mathrm{Acy} 1)$ & Halichondria sp. & North coast of $\mathrm{O}^{\prime} \mathrm{ahu}$, Hawaii & 1974 & {$[39,40]$} \\
\hline $\mathrm{R}=\mathrm{NCS}(\mathrm{Acy} 2)$ & Halichondria sp. & North coast of $\mathrm{O}^{\prime}$ ahu, Hawaii & 1974 & {$[39,40]$} \\
\hline $\mathrm{R}=\mathrm{NHCHO}(\mathbf{A c y} 3)$ & Halichondria sp. & North coast of $\mathrm{O}^{\prime} \mathrm{ahu}$, Hawaii & 1974 & {$[39,40]$} \\
\hline \multirow{2}{*}{ malonganenone C (Acy4) } & Leptogorgia gilchristi & Ponto Malongane, Mozambique & 2006 & [96] \\
\hline & Euplexaura nuttingi & Uvinage, Pemba Island, Tanzania & 2007 & [97] \\
\hline$\Delta^{11,12}-(E)($ Acy5) & Euplexaura nuttingi & Uvinage, Pemba Island, Tanzania & 2007 & [97] \\
\hline malonganenone K (Acy6) & Euplexaura robusta & Wei Zhou Island (Guanxi, China) & 2012 & [98] \\
\hline \multicolumn{5}{|c|}{ Kalihinoles } \\
\hline \multirow{10}{*}{ kalihinol A (Kol1) } & Acanthella sp. & Apra Harbor, Guam & 1984 & [100-102] \\
\hline & Acanthella cavernosa & Fiji & 1988 & [106] \\
\hline & Acanthella cavernosa & Pacific Harbor/Benga (=Beqa) Lagoon, Fiji & 1994 & [99] \\
\hline & Acanthella cavernosa & Yakushima Island, Japan & 1995 & {$[111]$} \\
\hline & Acanthella cavernosa & Yakushima Island, Japan & 1996 & [114] \\
\hline & Phakellia pulcherrima & Davao, Philippines & 1998 & [104] \\
\hline & Acanthella cavernosa & Coral reef, Ishigaki Island, Okinawa, Japan & 1998 & [105] \\
\hline & Phyllidiella pustulosa & Hainan Island, South China Sea & 2004 & [35] \\
\hline & Acanthella sp. & Yalong Bay, Hainan Province, China & 2009 & [103] \\
\hline & Acanthella cavernosa & Xisha Islets, South China Sea & 2012 & [107] \\
\hline
\end{tabular}


Table 1. Cont.

\begin{tabular}{|c|c|c|c|c|}
\hline Trivial Name (Structure) & Organism & Origin & Year & References \\
\hline \multirow{2}{*}{$10 \beta$-formamido kalihinol A (Kol2) } & Acanthella cavernosa & Hachiji-jima Island, Japan & 1996 & {$[20]$} \\
\hline & Acanthella cavernosa & Xisha Islets, South China Sea & 2012 & [107] \\
\hline \multirow{3}{*}{ kalihinol Z (Kol3) } & Acanthella sp. & Fish Patch, Vita Levu, Fiji & 1987 & [102] \\
\hline & Acanthella cavernosa & Fiji & 1988 & [106] \\
\hline & Phakellia pulcherrima & Davao, Philippines & 1998 & [104] \\
\hline \multirow{5}{*}{ kalihinol X (Kol4) } & Acanthella sp. & Fish Patch, Vita Levu, Fiji & 1987 & [102] \\
\hline & Acanthella cavernosa & Fiji & 1988 & [106] \\
\hline & Acanthella cavernosa & Thailand & 1991 & [49] \\
\hline & Phakellia pulcherrima & Philippines & 1998 & [104] \\
\hline & Acanthella cavernosa & Dibud, Philippines & 2004 & [109] \\
\hline \multirow{2}{*}{ 10-epi-kalihinol X (Kol5) } & Acanthella sp. & Yalong Bay, Hainan Province, China & 2009 & [103] \\
\hline & Acanthella cavernosa & Xisha Islets, South China Sea & 2012 & [107] \\
\hline \multirow{4}{*}{ kalihinol E (Kol6) } & Acanthella sp. & Apra Harbor, Guam & 1987 & {$[102]$} \\
\hline & Acanthella cavernosa & Hachiji-jima Island, Japan & 1996 & {$[20]$} \\
\hline & Phyllidiella pustulosa & Hainan Island, South China Sea & 2004 & [35] \\
\hline & Acanthella cavernosa & Xisha Islets, South China Sea & 2012 & [107] \\
\hline $10 \beta$-formamido kalihinol E (Kol7) & Acanthella cavernosa & Hachiji-jima Island, Japan & 1996 & {$[20]$} \\
\hline kalihinol O (Kol8) & Acanthella cavernosa & Xisha Islets, South China Sea & 2012 & [107] \\
\hline
\end{tabular}


Table 1. Cont.

\begin{tabular}{|c|c|c|c|c|}
\hline Trivial Name (Structure) & Organism & Origin & Year & References \\
\hline \multirow{5}{*}{ kalihinol Y(Kol9) } & Acanthella sp. & Fish Patch, Vita Levu, Fiji & 1987 & [102] \\
\hline & Acanthella cavernosa & Fiji & 1988 & [106] \\
\hline & Acanthella cavernosa & Thailand & 1991 & [49] \\
\hline & Phakellia pulcherrima & Philippines & 1998 & [104] \\
\hline & Acanthella cavernosa & Dibud, Philippines & 2004 & [109] \\
\hline \multirow{2}{*}{$\Delta^{9}$-kalihinol Y(Kol10) } & Phakellia pulcherrima & Davao, Philippines & 1998 & [104] \\
\hline & Acanthella cavernosa & Coral reef, Ishigaki Island, Okinawa, Japan & 1998 & [105] \\
\hline kalihinol P (Kol11) & Acanthella cavernosa & Xisha Islets, South China Sea & 2012 & [107] \\
\hline kalihinol S (Kol12) & Acanthella cavernosa & Xisha Islets, South China Sea & 2012 & [107] \\
\hline \multirow{2}{*}{ kalihinol J (Kol13) } & Acanthella cavernosa & Thailand & 1991 & [49] \\
\hline & Acanthella cavernosa & Dibud, Philippines & 2004 & [109] \\
\hline kalihinol I (Kol14) & Acanthella cavernosa & Thailand & 1991 & [49] \\
\hline \multirow{2}{*}{ 10-epi-kalihinol I (Kol15) } & Acanthella cavernosa & Coral reef, Ishigaki Island, Okinawa, Japan & 1998 & [105] \\
\hline & Acanthella cavernosa & Xisha Islets, South China Sea & 2012 & [107] \\
\hline \multirow[t]{2}{*}{$\begin{array}{l}10 \beta \text {-formamido- } 5 \beta \text {-isothiocyanato kalihinol A } \\
\text { (Kol16) }\end{array}$} & Acanthella cavernosa & Hachiji-jima Island, Japan & 1996 & {$[20]$} \\
\hline & Acanthella cavernosa & Xisha Islets, South China Sea & 2012 & [107] \\
\hline $10 \beta$-formamido- $5 \beta$-isocyanato kalihinol A (Kol17) & Acanthella cavernosa & Hachiji-jima Island, Japan & 1996 & {$[20]$} \\
\hline kalihinol Q (Kol18) & Acanthella cavernosa & Xisha Islets, South China Sea & 2012 & [107] \\
\hline kalihinol R (Kol19) & Acanthella cavernosa & Xisha Islets, South China Sea & 2012 & [107] \\
\hline
\end{tabular}


Table 1. Cont.

\begin{tabular}{|c|c|c|c|c|}
\hline Trivial Name (Structure) & Organism & Origin & Year & References \\
\hline \multirow{2}{*}{ kalihinol B (Kol20) } & Acanthella sp. & Apra Harbor, Guam & 1987 & [102] \\
\hline & Phakellia pulcherrima & Davao, Philippines & 1998 & [104] \\
\hline \multirow{4}{*}{ kalhinol F (Kol21) } & Acanthella sp. & Apra Harbor, Guam & 1987 & [100-102] \\
\hline & Acanthella cavernosa & Fiji & 1988 & [106] \\
\hline & Acanthella sp. & Cape Sada, Ehime Prefecture, Japan & 2003 & [108] \\
\hline & Acanthella cavernosa & Davao Gulf, Mindanao, Philippines & 2004 & [109] \\
\hline 10-formamido kalihinol F (Kol22) & Acanthella cavernosa & Davao Gulf, Mindanao, Philippines & 2004 & [109] \\
\hline 15-formamido kalihinol F(Kol23) & Acanthella cavernosa & Davao Gulf, Mindanao, Philippines & 2004 & [109] \\
\hline \multirow{2}{*}{ kalihinol G (Kol24) } & Acanthella sp. & Apra Harbor, Guam & 1987 & [102] \\
\hline & Acanthella cavernosa & Davao Gulf, Mindanao, Philippines & 2004 & [109] \\
\hline \multirow{2}{*}{ 10-isothiocyanato kalihinol G (Kol25) } & Phakellia pulcherrima & Philippines & 1998 & [104] \\
\hline & Acanthella cavernosa & Xisha Islets, South China Sea & 2012 & [107] \\
\hline kalihinol H (Kol26) & Acanthella sp. & Apra Harbor, Guam & 1987 & [102] \\
\hline 10-epi-kalihinol H (Kol27) & Phakellia pulcherrima & Davao, Philippines & 1998 & [104] \\
\hline \multirow{2}{*}{ kalihinol C (Kol28) } & Acanthella sp. & Apra Harbor, Guam & 1987 & [102] \\
\hline & Phakellia pulcherrima & Philippines & 1998 & [104] \\
\hline 10-isothiocyanato kalihinol C (Kol29) & Phakellia pulcherrima & Philippines & 1998 & [104] \\
\hline \multirow{2}{*}{ kalihinol D (Kol30) } & Acanthella sp. & Apra Harbor, Guam & 1987 & [102] \\
\hline & Acanthella sp. & Yalong Bay, Hainan Province, China & 2009 & [103] \\
\hline kalihinol T (Kol31) & Acanthella cavernosa & Xisha Islets, South China Sea & 2012 & [107] \\
\hline kalihinol K (Kol32) & Phakellia pulcherrima & Davao, Philippines & 1998 & [104] \\
\hline kalihinol L (Kol33) & Phakellia pulcherrima & Davao, Philippines & 1998 & [104] \\
\hline
\end{tabular}


Table 1. Cont

\begin{tabular}{|c|c|c|c|c|}
\hline Trivial Name (Structure) & Organism & Origin & Year & References \\
\hline 5,10-bisisothiocyanato kalihinol G (Kol34) & Acanthella cavernosa & Coral reef, Ishigaki Island, Okinawa, Japan & 1998 & [105] \\
\hline \multirow[t]{2}{*}{ isokalihinol B (Kol35) } & Acanthella cavernosa & $\begin{array}{c}\text { Kuchihoerabu Island, } \\
\text { Satsunan Archipel, Japan }\end{array}$ & 1990 & [110] \\
\hline & Acanthella cavernosa & Beau Vallon Beach, Mahé , Seychelles & 1994 & [112] \\
\hline \multirow{2}{*}{ isokalihinol F (Kol36) } & Acanthella cavernosa & Fiji & 1988 & [106] \\
\hline & Acanthella cavernosa & Pacific Harbor/Benga (=Beqa) Lagoon, Fiji & 1994 & [99] \\
\hline 10-epi-isokalihinol F (Kol37) & Acanthella cavernosa & Beau Vallon Beach, Mahé , Seychelles & 1994 & [112] \\
\hline 10-epi-isokalihinol H (Kol38) & Acanthella cavernosa & Beau Vallon Beach, Mahé, Seychelles & 1994 & [112] \\
\hline kalihinol M (Kol39) & Acanthella cavernosa & Xisha Islets, South China Sea & 2012 & [107] \\
\hline kalihinol N (Kol40) & Acanthella cavernosa & Xisha Islets, South China Sea & 2012 & [107] \\
\hline 8-OH-isokalihinol F (Kol41) & Acanthella cavernosa & Heron Island, Great Barrier Reef, Australia & 2000 & {$[31]$} \\
\hline \multicolumn{5}{|c|}{ kalihinenes } \\
\hline \multirow{6}{*}{ kalihinene (Ken1) } & Acanthella cavernosa & $\begin{array}{c}\text { Kuchihoerabu Island, } \\
\text { Satsunan Archipel, Japan }\end{array}$ & 1990 & [110] \\
\hline & Acanthella cavernosa & Pacific Harbor/Benga (=Beqa) Lagoon, Fiji & 1994 & [99] \\
\hline & Phakellia pulcherrima & Davao, Philippines & 1998 & [104] \\
\hline & Acanthella cavernosa & Coral reef, Ishigaki Island, Okinawa, Japan & 1998 & [105] \\
\hline & Phyllidiella pustulosa & Hainan Island, South China Sea & 2004 & [35] \\
\hline & Acanthella cavernosa & Davao Gulf, Mindanao, Philippines & 2004 & [109] \\
\hline
\end{tabular}


Table 1. Cont

\begin{tabular}{|c|c|c|c|c|}
\hline Trivial Name (Structure) & Organism & Origin & Year & References \\
\hline \multirow{3}{*}{ 15-formamido kalihinene (Ken2) } & Acanthella cavernosa & Pacific Harbor/Benga (=Beqa) Lagoon, Fiji & 1994 & [99] \\
\hline & Acanthella cavernosa & Yakushima Island, Japan & 1996 & [114] \\
\hline & Acanthella cavernosa & Xisha Islets, South China Sea & 2012 & [113] \\
\hline \multirow{4}{*}{ 10-formamido-kalihinene (Ken3) } & Acanthella cavernosa & Pacific Harbor/Benga (=Beqa) Lagoon, Fiji & 1994 & [99] \\
\hline & Acanthella cavernosa & Yakushima Island, Japan & 1995 & [111] \\
\hline & Acanthella cavernosa & Yakushima Island, Japan & 1996 & [114] \\
\hline & Acanthella cavernosa & Xisha Islets, South China Sea & 2012 & [113] \\
\hline 10,15-bisformamido kalihinene (Ken4) & Acanthella cavernosa & Pacific Harbor/Benga (=Beqa) Lagoon, Fiji & 1994 & [99] \\
\hline \multirow{2}{*}{ 6-hydroxy-kalihinene (Ken5) } & Acanthella cavernosa & Pacific Harbor/Benga (=Beqa) Lagoon, Fiji & 1994 & [99] \\
\hline & Acanthella cavernosa & Coral reef, Ishigaki Island, Okinawa, Japan & 1998 & [105] \\
\hline 6-hydroxy-15-formamido-kalihinene (Ken6) & Acanthella cavernosa & Pacific Harbor/Benga (=Beqa) Lagoon, Fiji & 1994 & [99] \\
\hline 6-hydroxy-10-formamido-kalihinene (Ken7) & Acanthella cavernosa & Pacific Harbor/Benga (=Beqa) Lagoon, Fiji & 1994 & [99] \\
\hline $\begin{array}{c}\text { 6-hydroxy-10-formamido-15- } \\
\text { isothiocyanato-kalihinene (Ken8) }\end{array}$ & Acanthella cavernosa & Pacific Harbor/Benga (=Beqa) Lagoon, Fiji & 1994 & [99] \\
\hline Kalihinene A/1,10-diepi-kalihinene (Ken9) & Acanthella cavernosa & Beau Vallon Beach, Mahé, Seychelles & 1994 & [112] \\
\hline \multirow{3}{*}{ Kalihinene B/1-epi-kalihinene (Ken10) } & Acanthella cavernosa & Beau Vallon Beach, Mahé, Seychelles & 1994 & [112] \\
\hline & Phakellia pulcherrima & Davao, Philippines & 1998 & [104] \\
\hline & Acanthella cavernosa & Heron Island, Great Barrier Reef, Australia & 2000 & [31] \\
\hline 15-isothiocyanato-1-epi-kalihinene (Ken11) & Acanthella cavernosa & Beau Vallon Beach, Mahé, Seychelles & 1994 & [112] \\
\hline
\end{tabular}


Table 1. Cont

\begin{tabular}{|c|c|c|c|c|}
\hline Trivial Name (Structure) & Organism & Origin & Year & References \\
\hline Kalihinene F (Ken12) & Acanthella cavernosa & Xisha Islets, South China Sea & 2012 & [113] \\
\hline Kalihinene E (Ken13) & Acanthella cavernosa & Xisha Islets, South China Sea & 2012 & [113] \\
\hline \multirow{3}{*}{ Kalihinene X (Ken14) } & Acanthella cavernosa & Yakushima Island, Japan & 1995 & [111] \\
\hline & Acanthella cavernosa & Yakushima Island, Japan & 1996 & [114] \\
\hline & Acanthella cavernosa & Xisha Islets, South China Sea & 2012 & [113] \\
\hline \multirow{3}{*}{ Kalihinene Y (Ken15) } & Acanthella cavernosa & Yakushima Island, Japan & 1995 & [111] \\
\hline & Acanthella cavernosa & Yakushima Island, Japan & 1996 & [114] \\
\hline & Acanthella cavernosa & Xisha Islets, South China Sea & 2012 & [113] \\
\hline \multirow{2}{*}{ Kalihinene Z (Ken16) } & Acanthella cavernosa & Yakushima Island, Japan & 1995 & [111] \\
\hline & Acanthella cavernosa & Yakushima Island, Japan & 1996 & [114] \\
\hline \multicolumn{5}{|c|}{ Kalihipyranes } \\
\hline \multirow{2}{*}{ Kalihipyran (Kpy1) } & Acanthella cavernosa & Beau Vallon Beach, Mahé, Seychelles & 1994 & [112] \\
\hline & Acanthella cavernosa & Heron Island, Great Barrier Reef, Australia & 2000 & {$[31]$} \\
\hline \multirow{2}{*}{ Kalihipyran A (Kpy2) } & Acanthella cavernosa & Yakushima Island, Japan & 1996 & [114] \\
\hline & Acanthella cavernosa & Xisha Islets, South China Sea & 2012 & [113] \\
\hline Kalihipyran B (Kpy3) & Acanthella cavernosa & Yakushima Island, Japan & 1996 & [114] \\
\hline Kalihipyran C (Kpy4) & Acanthella cavernosa & Xisha Islets, South China Sea & 2012 & [113] \\
\hline \multicolumn{5}{|c|}{ Intermediates } \\
\hline Cavernene A (Int1) & Acanthella cavernosa & Xisha Islets, South China Sea & 2012 & [113] \\
\hline Cavernene B (Int2) & Acanthella cavernosa & Xisha Islets, South China Sea & 2012 & [113] \\
\hline Cavernene C (Int3) & Acanthella cavernosa & Xisha Islets, South China Sea & 2012 & [113] \\
\hline Cavernene D (Int4) & Acanthella cavernosa & Xisha Islets, South China Sea & 2012 & [113] \\
\hline
\end{tabular}


Table 1. Cont

\begin{tabular}{|c|c|c|c|c|}
\hline Trivial Name (Structure) & Organism & Origin & Year & References \\
\hline (Int5) planar & Adocia & Miyako Island, Japan & 1992 & [116] \\
\hline $\begin{array}{l}\left(1 S^{*}, 6 R^{*}, 7 R^{*}, 10 S^{*}, 11 R^{*}\right)-10 \text { - } \\
\text { isothiocyanatobiflora-1,14-diene (Int5) }\end{array}$ & Cymbastela hooperi & Kelso Reef, Queensland, Australia & 1996 & [115] \\
\hline Pulcherrimol (Int6) & Phyllidiella pulcherrima & Davao, Philippines & 1998 & [104] \\
\hline 11,12-epoxy-10-isocyano-4,14-bifloradiene (Int7) & Acanthella cavernosa & Heron Island, Great Barrier Reef, Australia & 2000 & [31] \\
\hline 11,18-epoxy-10-isocyano-4,14-bifloradiene (Int8) & Acanthella cavernosa & Heron Island, Great Barrier Reef, Australia & 2000 & [31] \\
\hline \multicolumn{5}{|c|}{ Amphilectenes } \\
\hline \multirow{7}{*}{$\begin{array}{l}\text { 8,15-diisocyano-11(20)-amphilectene/(-)-DINCA } \\
\text { (Amp1) }\end{array}$} & Pseudoaxinella amphilecta & Glover Reef, Belize & 1978 & [119] \\
\hline & Phyllidiella pustulosa & Hainan Island, South China Sea & 2004 & [35] \\
\hline & Cribochalina sp. & Caribbean coast of Mexico & 2005 & [120] \\
\hline & Ciocalapata sp. (Halichondriidae) & Koh-Tao, Surat-Thani province, Thailand & 2009 & [122] \\
\hline & Pseudoaxinella flava & Sweeting Cay, Grand Bahamas & 2011 & [128] \\
\hline & Svenzea flava & Great Inagua Island, Bahamas & 2013 & [133] \\
\hline & Svenzea flava & Cabo Norte, Mona Island, Puerto Rico & $2012 / 2015$ & {$[125,160]$} \\
\hline \multirow{3}{*}{$\begin{array}{l}\text { 8-isocyano-15-formamido-11(20)-amphilectene } \\
\text { (Amp2) }\end{array}$} & Pseudoaxinella amphilecta & Glover Reef, Belize & 1978 & [119] \\
\hline & Svenzea flava & Great Inagua Island, Bahamas & 2013 & [133] \\
\hline & Svenzea flava & Cabo Norte, Mona Island, Puerto Rico & $2012 / 2015$ & {$[125,160]$} \\
\hline $\begin{array}{c}\text { 8-isocyano-15-isothiocyanato-11(20)-amphilectene } \\
\text { (Amp3) }\end{array}$ & Cribochalina sp. & Caribbean coast of Mexico & 2005 & [120] \\
\hline \multirow{2}{*}{$\begin{array}{l}\left(1 S^{*}, 3 S^{*}, 4 R^{*}, 7 S^{*}, 8 S^{*}, 12 S^{*}, 13 S^{*}\right)-8 \text {-isocyanato- } \\
\text { amphilecta-11(20),14-diene (Amp4) }\end{array}$} & Stylissa sp. & Coral reef, Iriomote Island, Okinawa, Japan & 2004 & [50] \\
\hline & Ciocalapata sp. (Halichondriidae) & Koh-Tao, Surat-Thani province, Thailand & 2009 & [122] \\
\hline
\end{tabular}


Table 1. Cont.

\begin{tabular}{|c|c|c|c|c|}
\hline Trivial Name (Structure) & Organism & Origin & Year & References \\
\hline 8-isocyano-10,14-amphilectadiene (Amp5) & Halichondria sp. & Palau & 1987 & [121] \\
\hline $\begin{array}{c}\left(3 S^{*}, 4 R^{*}, 7 S^{*}, 8 S^{*}, 11 S^{*}, 13 S^{*}\right) \text {-8-isocyanoamphilecta- } \\
\text { 1(12),14-diene (Amp6) }\end{array}$ & Stylissa sp. & Coral reef, Iriomote Island, Okinawa, Japan & 2004 & {$[50]$} \\
\hline 8-isocyanoamphilecta-11(20),15-diene (Amp7) & Ciocalapata sp. (Halichondriidae) & Koh-Tao, Surat-Thani province, Thailand & 2009 & [123] \\
\hline $\begin{array}{l}\text { 8-isocyanato-15-formamidoamphilect-11(20)-ene } \\
\text { (Amp8) }\end{array}$ & Stylissa cf. massa & Koh-Tao, Surat-Thani province, Thailand & 2012 & [123] \\
\hline $\begin{array}{l}\text { 8-isothiocyanato-15-formamidoamphilect-11(20)-ene } \\
\text { (Amp9) }\end{array}$ & Stylissa cf. massa & Koh-Tao, Surat-Thani province, Thailand & 2012 & [123] \\
\hline Monoamphilectine A (Amp10) & Svenzea flava & Cabo Norte, Mona Island, Puerto Rico & $\begin{array}{l}15 \\
\text { December } \\
2010\end{array}$ & {$[124,125,160]$} \\
\hline Monoamphilectine B (Amp11) & Svenzea flava & Cabo Norte, Mona Island, Puerto Rico & 2015 & [125] \\
\hline Monoamphilectine C (Amp12) & Svenzea flava & Cabo Norte, Mona Island, Puerto Rico & 2015 & [125] \\
\hline \multirow{3}{*}{$\begin{array}{c}\text { 7-isocyano-11(20),14-epiamphilectadien/ } \\
\left(1 R^{*}, 3 S^{*}, 4 R^{*}, 7 S^{*}, 8 S^{*}, 12 S^{*}, 13 S^{*}\right)-7- \\
\text { isocyanoamphilecta-11(20),14-diene (Amp13) }\end{array}$} & Adocia sp. & & 1980 & [126] \\
\hline & Cymbastela hooperi & Kelso Reef, Queensland, Australia & 1996 & [115] \\
\hline & Cribochalina sp. & Caribbean coast of Mexico & 2005 & [120] \\
\hline $\begin{array}{l}\left(1 R^{*}, 3 S^{*}, 4 R^{*}, 7 S^{*}, 8 S^{*}, 12 S^{*}, 13 S^{*}\right)-7 \text { - } \\
\text { formamidoamphilecta-11(20),14-diene (Amp14) }\end{array}$ & Cymbastela hooperi & Kelso Reef, Queensland, Australia & 2009 & [127] \\
\hline $\begin{array}{c}\left(1 R^{*}, 3 S^{*}, 4 R^{*}, 7 S^{*}, 8 S^{*}, 13 R^{*}\right)-7- \\
\text { isocyanoamphilecta-11,14-diene (Amp15) }\end{array}$ & Cymbastela hooperi & Kelso Reef, Queensland, Australia & 1996 & [115] \\
\hline \multirow{4}{*}{$\begin{array}{c}\left(1 S^{*}, 3 S^{*}, 4 R^{*}, 7 S^{*}, 8 S^{*}, 12 S^{*}, 13 S^{*}\right)-7- \\
\text { isocyanoamphilecta-11(20),15-diene (Amp16) }\end{array}$} & Cymbastela hooperi & Kelso Reef, Queensland, Australia & 1996 & [115] \\
\hline & Adocia sp. & & 1980 & [126] \\
\hline & Ciocalapata sp. (Halichondriidae) & Koh-Tao, Surat-Thani province, Thailand & 2009 & [122] \\
\hline & Svenzea flava & Cabo Norte, Mona Island, Puerto Rico & 2015 & [125] \\
\hline
\end{tabular}


Table 1. Cont

\begin{tabular}{|c|c|c|c|c|}
\hline Trivial Name (Structure) & Organism & Origin & Year & References \\
\hline $\begin{array}{l}\qquad\left(1 S^{*}, 3 S^{*}, 4 R^{*}, 7 S^{*}, 8 S^{*}, 12 S^{*}, 13 S^{*}\right)-7- \\
\text { Formamidoamphilecta-11(20),15-diene (Amp17) }\end{array}$ & Cymbastela hooperi & Kelso Reef, Queensland, Australia & 2009 & [127] \\
\hline $\begin{array}{c}\left(1 S^{*}, 3 S^{*}, 4 R^{*}, 7 S^{*}, 8 S^{*}, 12 S^{*}, 13 S^{*}-7-\right. \\
\text { isocyano-amphilecta-10,14-diene (Amp18) }\end{array}$ & Cymbastela hooperi & Kelso Reef, Queensland, Australia & 1996 & [115] \\
\hline $\begin{array}{c}\left(1 R^{*}, 3 S^{*}, 4 R^{*}, 7 S^{*}, 8 S^{*}, 12 S^{*}, 13 S^{*}\right)-7- \\
\text { isocyanoamphilecta-10,14-diene (Amp19) }\end{array}$ & Stylissa sp. & Iriomote Island, Okinawa, Japan & 2004 & {$[50]$} \\
\hline $\begin{array}{c}\left(1 R^{*}, 3 S^{*}, 4 R^{*}, 7 S^{*}, 8 S^{*}, 12 R^{*}, 13 R^{*}\right) \text {-12-hydroxy-7- } \\
\text { isothiocyanato-amphilecta-11(20),14-diene } \\
(\text { Amp20) }\end{array}$ & Cymbastela hooperi & Kelso Reef, Queensland, Australia & 1996 & [115] \\
\hline \multirow{3}{*}{ 7,15-diisocyano-11(20)-epiamphilectene (Amp21) } & Adocia sp. & & 1980 & [126] \\
\hline & Svenzea flava & Great Inagua Island, Bahamas & 2013 & [133] \\
\hline & Svenzea flava & Cabo Norte, Mona Island, Puerto Rico & 2015 & [125] \\
\hline $\begin{array}{c}\left(1 S^{*}, 3 S^{*}, 4 R^{*}, 7 S^{*}, 8 S^{*}, 12 S^{*}, 13 S^{*}\right)-7 \text {-isocyano- } \\
\text { 15-isothiocyanatoamphilecta-11(20)-ene (Amp22) }\end{array}$ & Cymbastela hooperi & Kelso Reef, Queensland, Australia & 1996 & [115] \\
\hline \multirow{3}{*}{ 7,15-diisocyano-11(20)-amphilectene (Amp23) } & Cribochalina sp. & Caribbean coast of Mexico & 2005 & [120] \\
\hline & Pseudoaxinella flava & Sweeting Cay, Grand Bahamas & 2011 & [128] \\
\hline & Svenzea flava & Cabo Norte, Mona Island, Puerto Rico & 2012 & [160] \\
\hline $\begin{array}{l}\text { 7-isocyano-15-isothiocyanato- } \\
\text { 11(20)-amphilectene (Amp24) }\end{array}$ & Cribochalina sp. & Caribbean coast of Mexico & 2005 & [120] \\
\hline \multirow{3}{*}{$\begin{array}{c}(1 S, 3 S, 4 R, 7 S, 8 R, 12 S, 13 S) \text {-7-isocyanoamphilecta- } \\
\text { 11(20),15-diene (Amp25) }\end{array}$} & Cribochalina sp. & Caribbean coast of Mexico & 2005 & [120] \\
\hline & Pseudoaxinella flava & Sweeting Cay, Grand Bahamas & 2011 & {$[128]$} \\
\hline & Svenzea flava & Cabo Norte, Mona Island, Puerto Rico & 2012 & {$[160]$} \\
\hline
\end{tabular}


Table 1. Cont

\begin{tabular}{|c|c|c|c|c|}
\hline Trivial Name (Structure) & Organism & Origin & Year & References \\
\hline (Amp26) & Pseudoaxinella flava & Sweeting Cay, Grand Bahamas & 2011 & {$[128]$} \\
\hline \multirow{3}{*}{ Biflora-4,9,15-triene (Amp27) } & Acanthella cavernosa & Hachiji-jima Island, Japan & 1996 & [20] \\
\hline & Acanthella cavernosa & Yakusha Island, Japan & 1996 & [114] \\
\hline & Cribochalina sp. & Caribbean coast of Mexico & 2005 & [120] \\
\hline \multicolumn{5}{|c|}{ Cycloamphilectenes } \\
\hline \multirow{2}{*}{ 8-isocyano-10-cycloamphilectene (Cam1) } & Adocia sp. & & 1980 & [126] \\
\hline & Cribochalina sp. & Caribbean coast of Mexico & 2005 & [120] \\
\hline 8-isothiocyanato-amphilect-10-ene (Cam2) & Stylissa sp. & Coral reef, Iriomote Island, Okinawa, Japan & 2004 & [50] \\
\hline 8-isocyanatocycloamphilect-10-ene (Cam3) & Stylissa sp. & Coral reef, Iriomote Island, Okinawa, Japan & 2004 & {$[50]$} \\
\hline \multirow{2}{*}{$\begin{array}{c}\left(3 S^{*}, 4 R^{*}, 7 S^{*}, 8 S^{*}, 11 S^{*}, 13 R^{*}\right) \text {-8-isocyano- } \\
1(12) \text {-cycloamphilectene (Cam4) }\end{array}$} & Halichondria sp. & Palau & 1987 & {$[121]$} \\
\hline & Adocia sp. & & 1980 & [126] \\
\hline $\begin{array}{c}\left(1 S^{*}, 3 S^{*}, 4 R^{*}, 7 S^{*}, 8 S^{*}, 12 S^{*}, 13 S^{*}\right)-7- \\
\text { isocyanocycloamphilect-11(20)-ene (Cam5) }\end{array}$ & Cymbastela hooperi & Kelso Reef, Queensland, Australia & 1996 & [115] \\
\hline $\begin{array}{l}\left(1 S^{*}, 3 S^{*}, 4 R^{*}, 7 S^{*}, 8 S^{*}, 12 S^{*}, 13 S^{*}\right)-7- \\
\text { Formamidocycloamphilect-11(20)-ene (Cam6) }\end{array}$ & Cymbastela hooperi & Kelso Reef, Queensland, Australia & 2009 & [127] \\
\hline $\begin{array}{c}\left(1 S^{*}, 3 S^{*}, 4 R^{*}, 7 S^{*}, 8 S^{*}, 12 S^{*}, 13 S^{*}\right)-7- \\
\text { isocyanocylcoamphilect-10-ene (Cam7) }\end{array}$ & Cymbastela hooperi & Kelso Reef, Queensland, Australia & 1996 & [115] \\
\hline $\begin{array}{c}\left(1 S^{*}, 3 S^{*}, 4 R^{*}, 7 S^{*}, 8 R^{*}, 13 R^{*}\right) \text {-7-isocyano- } \\
\text { 11-cycloamphilectene (Cam8) }\end{array}$ & Halichondria sp. & Palau & 1987 & [121] \\
\hline $\begin{array}{l}\left(1 S^{*}, 3 S^{*}, 4 R^{*}, 7 S^{*}, 8 R^{*}, 13 R^{*}\right) \text { - } N \text {-formyl-7- } \\
\text { amino-11-cycloamphilectene (Cam9) }\end{array}$ & Axinella sp. & Vanuatu & 2002 & [129] \\
\hline $\begin{array}{c}\left(3 S^{*}, 4 R^{*}, 7 S^{*}, 8 R^{*}, 11 S^{*}, 12 R^{*}, 13 S^{*}\right)-7- \\
\text { isocyano-1-cycloamphilectene (Cam10) }\end{array}$ & Halichondria sp. & Palau & 1987 & [121] \\
\hline
\end{tabular}


Table 1. Cont

\begin{tabular}{|c|c|c|c|c|}
\hline Trivial Name (Structure) & Organism & Origin & Year & References \\
\hline \multicolumn{5}{|c|}{ Isocycloamphilectanes } \\
\hline \multirow{3}{*}{$\begin{array}{c}\text { diisocyanoadociane } /(1 S, 3 S, 4 R, 7 S, 8 S, 11 S, 12 S \text {, } \\
13 S, 15 R, 20 R)-7,20 \text {-diisocyanoisocycloamphilectane } \\
\text { (Ica1) }\end{array}$} & Adocia & Great Barrier Reef, Townsville, Australia & 1976 & [130] \\
\hline & Cymbastela hooperi & Kelso Reef, Queensland, Australia & 1996 & [115] \\
\hline & Cribochalina sp. & Caribbean coast of Mexico & 2005 & [120] \\
\hline $\begin{array}{c}(1 S, 3 S, 4 R, 7 S, 8 S, 11 S, 12 S, 13 S, 15 R, 20 R)-20- \\
\text { isocyano-7-isocyanatoisocycloamphilectane (Ica2) }\end{array}$ & Cymbastela hooperi & Kelso Reef, Queensland, Australia & 1996 & [115] \\
\hline $\begin{array}{c}(1 S, 3 S, 4 R, 7 S, 8 S, 11 S, 12 S, 13 S, 15 R, 20 R)-20- \\
\text { isocyanato-7-isocyanoisocycloamphilectane (Ica4) }\end{array}$ & Cymbastela hooperi & Kelso Reef, Queensland, Australia & 1996 & [115] \\
\hline $\begin{array}{c}(1 S, 3 S, 4 R, 7 S, 8 S, 11 S, 12 S, 13 S, 15 R, 20 R)-7- \\
\text { Formamido-10-isocyanoisocycloamphilectane } \\
\text { (Ica5) }\end{array}$ & Cymbastela hooperi & Kelso Reef, Queensland, Australia & 2009 & [127] \\
\hline $\begin{array}{l}(1 S, 3 S, 4 R, 7 S, 8 S, 11 S, 12 S, 13 S, 15 R, 20 R)-7,20- \\
\text { Diformamidoisocycloamphilectane (Ica6) }\end{array}$ & Cymbastela hooperi & Kelso Reef, Queensland, Australia & 2009 & [127] \\
\hline 7,15-diisocyanoadociane (Ica7) & Adocia sp. & & 1980 & [126] \\
\hline $\begin{array}{l}\left(1 S^{*}, 3 S^{*}, 4 R^{*}, 7 S^{*}, 8 S^{*}, 11 R^{*}, 12 R^{*}, 13 S^{*}, 20 S^{*}\right)-7- \\
\text { isocyanoisocycloamphilect-14-ene (Ica8) }\end{array}$ & Cymbastela hooperi & Kelso Reef, Queensland, Australia & 1996 & [115] \\
\hline \multicolumn{5}{|c|}{ Neoamphilectenes } \\
\hline 7-isocyanoneoamphilecta-11,15-diene (Neo1) & Adocia & Miyako Island, Japan & 1992 & [116] \\
\hline
\end{tabular}


Table 1. Cont.

\begin{tabular}{|c|c|c|c|c|}
\hline Trivial Name (Structure) & Organism & Origin & Year & References \\
\hline \multicolumn{5}{|c|}{ Isoneoamphilectenes } \\
\hline \multirow[t]{2}{*}{ 7-isocyanoneoamphilecta-1(14),15-diene (Ina1) } & Cymbastela hooperi & Kelso Reef, Queensland, Australia & 1996 & [115] \\
\hline & Svenzea flava & Great Inagua Island, Bahamas & 2013 & [133] \\
\hline $\begin{array}{l}\text { 7-formamidoisoneoamphilecta-1(14),15-diene } \\
\text { (Ina2) }\end{array}$ & Svenzea flava & Great Inagua Island, Bahamas & 2013 & [133] \\
\hline $\begin{array}{l}\text { 7-methylaminoisoneoamphilecta-1(14),15-diene } \\
\text { (Ina3) }\end{array}$ & Svenzea flava & Great Inagua Island, Bahamas & 2013 & [133] \\
\hline \multicolumn{5}{|c|}{ Carbonimidic dichlorides } \\
\hline Stylotellane A (Dcl1) & Stylotella aurantium & $\begin{array}{l}\text { Coral Garden, Heron Island, } \\
\text { Great Barrier Reef, Australia }\end{array}$ & 1997 & {$[71]$} \\
\hline \multirow{4}{*}{ Stylotellane B (Dc12) } & Pseudoaxinella pitys & Indo-pacific & 1977 & [134] \\
\hline & Stylotella aurantium & $\begin{array}{l}\text { Coral Gardens, Heron Island, } \\
\text { Great Barrier Reef, Australia }\end{array}$ & 1997 & {$[71]$} \\
\hline & Ulosa spongia & Wistari Reef, Great Barrier Reef, Australia & 2001 & [136] \\
\hline & Stylotella aurantium & Iriomate Island, Okinawa, Japan & 2001 & [137] \\
\hline \multirow{2}{*}{ Ulosin A (Dcl3) } & Ulosa spongia & Wistari Reef, Great Barrier Reef, Australia & 2001 & [136] \\
\hline & Stylotella aurantium & Iriomate Island, Okinawa, Japan & 2001 & [137] \\
\hline Ulosin B (Dcl4) & Ulosa spongia & Wistari Reef, Great Barrier Reef, Australia & 2001 & [136] \\
\hline Axinyssimide A (Dcl5) & Axinyssa & Hachijo-jima Island, Japan & 1998 & [53] \\
\hline Axinyssimide B (Dcl6) & Axinyssa & Hachijo-jima Island, Japan & 1998 & [53] \\
\hline Axinyssimide C (Dcl7) & Axinyssa & Hachijo-jima Island, Japan & 1998 & [53] \\
\hline
\end{tabular}


Table 1. Cont.

\begin{tabular}{|c|c|c|c|c|}
\hline Trivial Name (Structure) & Organism & Origin & Year & References \\
\hline \multirow{3}{*}{$\begin{array}{c}\left(1 R^{*}, 5 S^{*}, 6 S^{*}\right)-6,14 \text {-dichloro-5-hydroxy-9,3(14)- } \\
\text { (Z)-axinyssadien-15-yl-carbonimidic dichloride } \\
\text { (Dcl8) }\end{array}$} & Pseudoaxinella pitys & Indo-pacific & 1977 & [134] \\
\hline & Reticulidia fungia & Irabu Island, Okinawa, Japan & 1999 & [141] \\
\hline & Stylotella aurantium & Iriomate Island, Okinawa, Japan & 2001 & [137] \\
\hline $\mathrm{R}=\mathrm{H}$ (Dc19) & Stylotella aurantium & & 2004 & [138] \\
\hline (Dcl10) & Stylotella aurantium & Iriomate Island, Okinawa, Japan & 2001 & [137] \\
\hline \multirow{2}{*}{ (Dcl11) } & Pseudoaxinella pitys & Indo-pacific & 1978 & [140] \\
\hline & Stylotella aurantium & Iriomate Island, Okinawa, Japan & 2001 & [137] \\
\hline \multirow{2}{*}{ (Dcl12) } & Pseudoaxinella pitys & Indo-pacific & 1978 & [140] \\
\hline & Stylotella aurantium & Iriomate Island, Okinawa, Japan & 2001 & [137] \\
\hline \multirow{2}{*}{ (Dcl13) } & Pseudoaxinella pitys & Indo-pacific & 1978 & [140] \\
\hline & Stylotella aurantium & Iriomate Island, Okinawa, Japan & 2001 & [137] \\
\hline (Dcl14) & Stylotella aurantium & Iriomate Island, Okinawa, Japan & 2001 & [137] \\
\hline \multirow{2}{*}{ Reticulidin A (Dcl15) } & Reticulidia fungia & Irabu Island, Okinawa, Japan & 1999 & [141] \\
\hline & Stylotella aurantium & Iriomate Island, Okinawa, Japan & 2001 & [137] \\
\hline \multirow{3}{*}{ Reticulidin B (Dcl16) } & Reticulidia fungia & Irabu Island, Okinawa, Japan & 1999 & [141] \\
\hline & Ulosa spongia & Wistari Reef, Great Barrier Reef, Australia & 2001 & [136] \\
\hline & Stylotella aurantium & Iriomate Island, Okinawa, Japan & 2001 & [137] \\
\hline \multirow{4}{*}{ Isoreticulidin B (Dcl17) } & Pseudoaxinella pitys & Indo-pacific & 1977 & [134] \\
\hline & Reticulidia fungia & Irabu Island, Okinawa, Japan & 1999 & [141] \\
\hline & Ulosa spongia & Wistari Reef, Great Barrier Reef, Australia & 2001 & [136] \\
\hline & Stylotella aurantium & Iriomate Island, Okinawa, Japan & 2001 & [137] \\
\hline
\end{tabular}


Table 1. Cont

\begin{tabular}{|c|c|c|c|c|}
\hline Trivial Name (Structure) & Organism & Origin & Year & References \\
\hline \multicolumn{5}{|c|}{ Other marine isonitriles } \\
\hline Farnesyl isothiocyanate (Mis1) & Stylotella aurantium & Heron Island, Great Barrier Reef, Australia & 1997 & [71] \\
\hline Farnesyl formamide (Mis2) & Axinyssa sp. & Sanya, Hainan Province, China & 2008 & [84] \\
\hline Isofarnesyl formamide (Mis4) & Axinyssa sp. & Sanya, Hainan Province, China & 2008 & {$[84]$} \\
\hline$(R)-(-)$-actisonitrile (Mis5) & Actinocyclis papillatus & Wei Zhou Island, South China Sea, China & 2011 & [142] \\
\hline $\begin{array}{c}(2 R, 3 S) \text {-2-formamide-1,3dihydroxy-octadecane } \\
\text { (Mis6) }\end{array}$ & Gracilaria verrucosa & Jeju Island, South Korea & 2008 & [143] \\
\hline Clavaminol L (Mis7) & Clavelina plegraea & Bay of Naples, Itlay & 2009 & [144] \\
\hline (Mis8-Mis28) & Pseudoaxinyssa sp. & Fiji & 1987 & [145] \\
\hline Axinyssina A (Mis29) & Axinyssa sp. & Inner coral reef, Andaman Sea, Thailand & 2014 & [92] \\
\hline Axinyssine B (Mis30) & Axinyssa sp. & Inner coral reef, Andaman Sea, Thailand & 2014 & [92] \\
\hline $\begin{array}{l}\text { 1-acetyl-4-formamido-4-methylcyclohexane } \\
\text { (Mis31) }\end{array}$ & Axinyssa sp. & Inner coral reef, Andaman Sea, Thailand & 2014 & [92] \\
\hline 1-acetyl-4-isocyano-4-methylcyclohexane (Mis32) & Phyllidia sp. & Colombo, Sri Lanka & 1986 & [74] \\
\hline Thiocyanatin A (Mis33) & Oceanapia sp. & Northern Rottnest shelf, Australia & 2001 & [146] \\
\hline Thiocyanatin B (Mis34) & Oceanapia sp. & Northern Rottnest shelf, Australia & 2001 & [146] \\
\hline Thiocyanatin C (Mis35) & Oceanapia sp. & Northern Rottnest shelf, Australia & 2001 & [146] \\
\hline Cylindricine A (Mis36) & Clavelina cylindrica & Deep Glen Bay, East Coast, Tasmania & 1994 & [147] \\
\hline
\end{tabular}


Table 1. Cont

\begin{tabular}{|c|c|c|c|c|}
\hline Trivial Name (Structure) & Organism & Origin & Year & References \\
\hline Cylindricine C (Mis37) & Clavelina cylindrica & Deep Glen Bay, East Coast, Tasmania & 1994 & [147] \\
\hline Cylindricine D (Mis38) & Clavelina cylindrica & Deep Glen Bay, East Coast, Tasmania & 1994 & [147] \\
\hline Cylindricine E (Mis39) & Clavelina cylindrica & Deep Glen Bay, East Coast, Tasmania & 1994 & [147] \\
\hline Cylindricine F (Mis40) & Clavelina cylindrica & $\begin{array}{c}\text { Bay of Islands, South Bruny Island, } \\
\text { Tasmania }\end{array}$ & 1994 & [147] \\
\hline Cylindricine G (Mis41) & Clavelina cylindrica & $\begin{array}{c}\text { Bay of Islands, South Bruny Island, } \\
\text { Tasmania }\end{array}$ & 1994 & [147] \\
\hline Cylindricine H (Mis42) & Clavelina cylindrica & Tasmania & 1995 & [148] \\
\hline Cylindricine I (Mis43) & Clavelina cylindrica & Tasmania & 1995 & [148] \\
\hline Cylindricine B (Mis44) & Clavelina cylindrica & Deep Glen Bay, East Coast, Tasmania & 1994 & [147] \\
\hline Cylindricine J (Mis45) & Clavelina cylindrica & Tasmania & 1995 & [148] \\
\hline Fasicularin (Mis46) & Nephtheis fasicularis & Micronesia & 1997 & [149] \\
\hline Psammaplin B (Mis47) & Psammaplysilla purpurea & & 1991 & [150] \\
\hline
\end{tabular}


Acknowledgments: We thank the Rhineland Palatinate Center for Natural Product Research and the Carl Zeiss foundation for financial support.

Conflicts of Interest: The authors declare no conflict of interest.

\section{References}

1. Rothe, W. Vorläufige Mitteilung über ein neues Antibiotikum. Pharmazie 1950, 5, 190.

2. Cafieri, F.; Fattorusso, E.; Magno, S.; Santacroce, C.; Sica, D. Isolation and structure of axisonitrile-1 and axisothiocyanate-1 two unusual sesquiterpenoids from the marine sponge Axinella cannabina. Tetrahedron 1973, 29, 4259-4262. [CrossRef]

3. Minale, L.; Riccio, R.; Sodano, G. Acanthellin-1, an unique isonitrile sesquiterpene from the sponge Acanthella acuta. Tetrahedron 1974, 30, 1341-1343. [CrossRef]

4. Fattorusso, E.; Magno, S.; Mayol, L.; Santacroce, C.; Sica, D. Isolation and structure of axisonitrile-2. Tetrahedron 1974, 30, 3911-3913. [CrossRef]

5. Fattorusso, E.; Magno, S.; Mayol, L.; Santacroce, C.; Sica, D. New sesquiterpenoids from the sponge Axinella cannabina. Tetrahedron 1975, 31, 269-270. [CrossRef]

6. Burreson, B.J.; Christophersen, C.; Scheuer, P.J. Cooccurrence of a terpenoid isocyanide-formamide pair in the marine sponge Halichondria species. J. Am. Chem. Soc. 1975, 97, 201-202. [CrossRef]

7. Edenborough, M.S.; Herbert, R.B. Naturally occurring isocyanides. Nat. Prod. Rep. 1988, 5, $229-245$. [CrossRef] [PubMed]

8. Chang, C.W.J.; Scheuer, P.J. Marine isocyano compounds. In Studies in Natural Products Chemistry; Scheuer, P.J., Ed.; Springer-Verlag: Berlin, Germany, 1993; Volume 167, pp. 33-75.

9. Chang, C.W.J. Naturally occurring isocyano/isothiocyanato and related compounds. In Fortschritte der Chemie Organischer Naturstoffe; Springer: New York, NY, USA, 2000; Volume 80.

10. Garson, M.J.; Simpson, J.S.; Flowers, A.E.; Dumdei, E.J. Cyanide and thiocyanate-derived functionality in marine organisms-Structures, biosynthesis and ecology. In Studies in Natural Products Chemistry; Atta ur, R., Ed.; Elsevier: Amsterdam, The Netherlands, 2000; Volume 21, Part B; pp. 329-372.

11. Garson, M.J. Biosynthetic studies on marine natural products. Nat. Prod. Rep. 1989, 6, 143-170. [CrossRef]

12. Chang, C.W.J.; Scheuer, P.J. Biosynthesis of marine isocyanoterpenoids in sponges. Comparative Biochem. Physiol. Part B: Comp. Biochem. 1990, 97, 227-233. [CrossRef]

13. Garson, M.J. The biosynthesis of marine natural products. Chem. Rev. 1993, 93, 1699-1733. [CrossRef]

14. Garson, M.J.; Simpson, J.S. Marine isocyanides and related natural products-Structure, biosynthesis and ecology. Nat. Prod. Rep. 2004, 21, 164-179. [CrossRef] [PubMed]

15. Schnermann, M.J.; Shenvi, R.A. Syntheses and biological studies of marine terpenoids derived from inorganic cyanide. Nat. Prod. Rep. 2015, 32, 543-577. [CrossRef] [PubMed]

16. Iengo, A.; Mayol, L.; Santacroce, C. Minor sesquiterpenoids from the sponge Axinella cannabina. Experientia 1977, 33, 11-12. [CrossRef]

17. Adinolfi, M.; de Napoli, L.; Di Blasio, B.; Iengo, A.; Pedone, C.; Santacroce, C. The absolute configuration of the axane sesquiterpenes from the sponge Axinella cannabina. Tetrahedron Lett. 1977, 18, 2815-2816. [CrossRef]

18. Piers, E.; Yeung, B.W.A. Total syntheses of the sesquiterpenoids $( \pm)$-axamide- $1,( \pm)$-axisonitrile- 1 , and the corresponding C-10 epimers. Can. J. Chem. 1986, 64, 2475-2476. [CrossRef]

19. Fusetani, N.; Wolstenholme, H.J.; Shinoda, K.; Asai, N.; Matsunaga, S.; Onuki, H.; Hirota, H. Two sesquiterpene isocyanides and a sesquiterpene thiocyanate from the marine sponge Acanthella cf. cavernosa and the Nudibranch Phyllidia ocellata. Tetrahedron Lett. 1992, 33, 6823-6826. [CrossRef]

20. Hirota, H.; Tomono, Y.; Fusetani, N. Terpenoids with antifouling activity against barnacle larvae from the marine sponge Acanthella cavernosa. Tetrahedron 1996, 52, 2359-2368. [CrossRef]

21. Ciminiello, P.; Fattorusso, E.; Magno, S.; Mayol, L. New nitrogenous sesquiterpenes from the marine sponge Axinella cannabina. J. Org. Chem. 1984, 49, 3949-3951. [CrossRef]

22. Ciminiello, P.; Magno, S.; Mayol, L.; Piccialli, V. Cis-Eudesmane nitrogenous metabolites from the marine sponges Axinella cannabina and Acanthella acuta. J. Nat. Prod. 1987, 50, 217-220. [CrossRef]

23. Burgoyne, D.L.; Dumdei, E.J.; Andersen, R.J. Acanthenes A to C: A chloro, isothiocyanate, formamide sesquiterpene triad isolated from the Northeastern Pacific marine sponge Acanthella sp. and the dorid nudibranch Cadlina luteomarginata. Tetrahedron 1993, 49, 4503-4510. [CrossRef] 
24. Ishiyama, H.; Hashimoto, A.; Fromont, J.; Hoshino, Y.; Mikami, Y.; Kobayashi, J.I. Halichonadins A-D, new sesquiterpenoids from a sponge Halichondria sp. Tetrahedron 2005, 61, 1101-1105. [CrossRef]

25. Ciminiello, P.; Fattorusso, E.; Magno, S.; Mayol, L. New nitrogenous sesquiterpenes based on alloaromadendrane and epi-eudesmane skeletons from the marine sponge Axinella cannabina. Can. J. Chem. 1987, 65, 518-522. [CrossRef]

26. Petrichtcheva, N.V.; Duque, C.; Dueñas, A.; Zea, S.; Hara, N.; Fujimoto, Y. New nitrogenous eudesmane-type compounds isolated from the Caribbean sponge Axinyssa ambrosia. J. Nat. Prod. 2002, 65, 851-855. [CrossRef] [PubMed]

27. Lyakhova, E.G.; Kolesnikova, S.A.; Kalinovskii, A.I.; Stonik, V.A. Secondary metabolites of the Vietnamese nudibranch mollusk Phyllidiella pustulosa. Chem. Nat. Compd. 2010, 46, 534-538. [CrossRef]

28. Capon, R.; Macleod, J. New Isothiocyanate Sesquiterpenes From the Australian Marine Sponge Acanthella pulcherrima. Aust. J. Chem. 1988, 41, 979-983. [CrossRef]

29. Angerhofer, C.K.; Pezzuto, J.M.; König, G.M.; Wright, A.D.; Sticher, O. Antimalarial activity of sesquiterpenes from the marine sponge Acanthella klethra. J. Nat. Prod. 1992, 55, 1787-1789. [CrossRef] [PubMed]

30. König, G.M.; Wright, A.D.; Sticher, O.; Fronczek, F.R. Two New Sesquiterpene Isothiocyanates from the Marine Sponge Acanthella klethra. J. Nat. Prod. 1992, 55, 633-638. [CrossRef]

31. Clark, R.J.; Stapleton, B.L.; Garson, M.J. New Isocyano and Isothiocyanato Terpene Metabolites from the Tropical Marine Sponge Acanthella cavernosa. Tetrahedron 2000, 56, 3071-3076. [CrossRef]

32. Jumaryatno, P.; Stapleton, B.L.; Hooper, J.N.A.; Brecknell, D.J.; Blanchfield, J.T.; Garson, M.J. A Comparison of Sesquiterpene Scaffolds across Different Populations of the Tropical Marine Sponge Acanthella cavernosa. J. Nat. Prod. 2007, 70, 1725-1730. [CrossRef] [PubMed]

33. Zubía, E.; Ortega, M.J.; Carballo, J.L. Sesquiterpenes from the Sponge Axinyssa isabela. J. Nat. Prod. 2008, 71, 2004-2010. [CrossRef] [PubMed]

34. Pais, M.; Fontaine, C.; Lauren, D.; La Barre, S.; Guittet, E. Stylotelline, a new sesquiterpene isocyanide from the sponge Stylotella sp., application of 2D-NMR in structure determination. Tetrahedron Lett. 1987, 28, 1409-1412. [CrossRef]

35. Manzo, E.; Ciavatta, M.L.; Gavagnin, M.; Mollo, E.; Guo, Y.-W.; Cimino, G. Isocyanide Terpene Metabolites of Phyllidiella pustulosa, a Nudibranch from the South China Sea. J. Nat. Prod. 2004, 67, 1701-1704. [CrossRef] [PubMed]

36. Lan, W.-J.; Wan, H.-P.; Li, G.-X.; Li, H.-J.; Chen, Y.-Y.; Liao, C.-Z.; Cai, J.-W. New Sesquiterpene Formamides from the Marine Sponge Axinyssa sp. Helv. Chim. Acta 2008, 91, 426-434. [CrossRef]

37. Kozawa, S.; Ishiyama, H.; Fromont, J.; Kobayashi, J. Halichonadin E. a Dimeric Sesquiterpenoid from the Sponge Halichondria sp. J. Nat. Prod. 2008, 71, 445-447. [CrossRef] [PubMed]

38. Suto, S.; Tanaka, N.; Fromont, J.; Kobayashi, J.I. Halichonadins G-J, new sesquiterpenoids from a sponge Halichondria sp. Tetrahedron Lett. 2011, 52, 3470-3473. [CrossRef]

39. Burreson, B.J.; Christophersen, C.; Scheuer, P.J. Co-occurrence of two terpenoid isocyanide-formamide pairs in a marine sponge (Halichondria sp.). Tetrahedron 1975, 31, 2015-2018. [CrossRef]

40. Burreson, B.J.; Scheuer, P.J. Isolation of a diterpenoid isonitrile from a marine sponge. J. Chem. Soc., Chem. Commun. 1974, 1035-1036. [CrossRef]

41. Young, R.M.; Adendorff, M.R.; Wright, A.D.; Davies-Coleman, M.T. Antiplasmodial activity: The first proof of inhibition of heme crystallization by marine isonitriles. Eur. J. Med. Chem. 2015, 93, 373-380. [CrossRef] [PubMed]

42. Okino, T.; Yoshimura, E.; Hirota, H.; Fusetani, N. New antifouling sesquiterpenes from four nudibranchs of the family Phyllidiidae. Tetrahedron 1996, 52, 9447-9454. [CrossRef]

43. Marcus, A.H.; Molinski, T.F.; Fahy, E.; Faulkner, D.J.; Xu, C.; Clardy, J. 5-Isothiocyanatopupukeanane from a sponge of the genus Axinyssa. J. Org. Chem. 1989, 54, 5184-5186. [CrossRef]

44. Ciminiello, P.; Fattorusso, E.; Magno, S.; Mayol, L. Minor nitrogenous sesquiterpenes from the marine sponge Axinella cannabina. A hypothesis for the biogenesis of the spiro-axane skeleton. Experientia 1986, 42, 625-627. [CrossRef]

45. Nakamura, H.; Deng, S.; Takamatsu, M.; Kobayashi, J.I.; Ohizumi, Y.; Hirata, Y. Structure of Halipanicine, a New Sesquiterpene Isothiocyanate from the Okinawan Marine Sponge Halichondria panicea (Pallas). Agricultural and Biological Chemistry 1991, 55, 581-583. [CrossRef] 
46. Compagnone, R.S.; Faulkner, D.J. Metabolites of the Palauan Sponge Axinyssa aplysinoides. J. Nat. Prod. 1995, 58, 145-148. [CrossRef] [PubMed]

47. Fusetani, N.; Wolstenholme, H.J.; Matsunaga, S.; Hirota, H. Two new sesquiterpene isonitriles from the nudibranch, phyllida pustulosa. Tetrahedron Lett. 1991, 32, 7291-7294. [CrossRef]

48. Nishikawa, K.; Umezawa, T.; Garson, M.J.; Matsuda, F. Confirmation of the Configuration of 10-Isothiocyanato-4-cadinene Diastereomers through Synthesis. J. Nat. Prod. 2012, 75, 2232-2235. [CrossRef] [PubMed]

49. Alvi, K.A.; Tenenbaum, L.; Crews, P. Anthelmintic Polyfunctional Nitrogen-Containing Terpenoids from Marine Sponges. J. Nat. Prod. 1991, 54, 71-78. [CrossRef] [PubMed]

50. Mitome, H.; Shirato, N.; Miyaoka, H.; Yamada, Y.; van Soest, R.W.M. Terpene Isocyanides, Isocyanates, and Isothiocyanates from the Okinawan Marine Sponge Stylissa sp. J. Nat. Prod. 2004, 67, 833-837. [CrossRef] [PubMed]

51. Zubía, E.; Ortega, M.J.; Hernández-Guerrero, C.J.; Carballo, J.L. Isothiocyanate Sesquiterpenes from a Sponge of the Genus Axinyssa. J. Nat. Prod. 2008, 71, 608-614. [CrossRef] [PubMed]

52. He, H.Y.; Faulkner, D.J.; Shumsky, J.S.; Hong, K.; Clardy, J. A sesquiterpene thiocyanate and three sesquiterpene isothiocyanates from the sponge Trachyopsis aplysinoides. J. Org. Chem. 1989, 54, 2511-2514. [CrossRef]

53. Hirota, H.; Okino, T.; Yoshimura, E.; Fusetani, N. Five new antifouling sesquiterpenes from two marine sponges of the genus Axinyssa and the nudibranch Phyllidia pustulosa. Tetrahedron 1998, 54, 13971-13980. [CrossRef]

54. Sorek, H.; Zelikoff, A.L.; Benayahu, Y.; Kashman, Y. Axiplyns A-E, new sesquiterpene isothiocyanates from the marine sponge Axinyssa aplysinoides. Tetrahedron Lett. 2008, 49, 2200-2203. [CrossRef]

55. Di Blasio, B.; Fattorusso, E.; Magno, S.; Mayol, L.; Pedone, C.; Santacroce, C.; Sica, D. Axisonitrile-3, axisothiocyanate-3 and axamide-3. Sesquiterpenes with a novel spiro[4,5]decane skeleton from the sponge Axinella cannabina. Tetrahedron 1976, 32, 473-478. [CrossRef]

56. Caine, D.; Deutsch, H. Total synthesis of (-)-axisonitrile-3. An application of the reductive ring opening of vinylcyclopropanes. J. Am. Chem. Soc. 1978, 100, 8030-8031. [CrossRef]

57. Braekman, J.C.; Daloze, D.; Deneubourg, F.; Huysecom, J.; Vandevyver, G. I-Isocyanoaromadendrane, A New Isonitrile Sesquiterpene from the Sponge Acanthella Acuta. Bull. Soc. Chim. Belg. 1987, 96, 539-543. [CrossRef]

58. Jumaryatno, P.; Rands-Trevor, K.; Blanchfield, J.T.; Garson, M.J. Isocyanates in marine sponges: Axisocyanate-3, a new sesquiterpene from Acanthella cavernosa. Arkivoc 2007, 157-166.

59. Prawat, H.; Mahidol, C.; Wittayalai, S.; Intachote, P.; Kanchanapoom, T.; Ruchirawat, S. Nitrogenous sesquiterpenes from the Thai marine sponge Halichondria sp. Tetrahedron 2011, 67, 5651-5655. [CrossRef]

60. Uy, M.M.; Ohta, S.; Yanai, M.; Ohta, E.; Hirata, T.; Ikegami, S. New spirocyclic sesquiterpenes from the marine sponge Geodia exigua. Tetrahedron 2003, 59, 731-736. [CrossRef]

61. Yan, X.H.; Zhu, X.Z.; Yu, J.L.; Jin, D.Z.; Guo, Y.W.; Mollo, E.; Cimino, G. 3-Oxo-axisonitrile-3, a new sesquiterpene isocyanide from the Chinese marine sponge Acanthella sp. J. Asian Nat. Prod. Res. 2006, 8, 579-584. [CrossRef] [PubMed]

62. Mayol, L.; Piccialli, V.; Sica, D. Nitrogenous sesquiterpenes from the marine sponge acanthella acuta: Three new isocyanide-isothiocyanate pairs. Tetrahedron 1987, 43, 5381-5388. [CrossRef]

63. Wegerski, C.J.; Sonnenschein, R.N.; Cabriales, F.; Valeriote, F.A.; Matainaho, T.; Crews, P. Stereochemical challenges in characterizing nitrogenous spiro-axane sesquiterpenes from the Indo-Pacific sponges Amorphinopsis and Axinyssa. Tetrahedron 2006, 62, 10393-10399. [CrossRef]

64. Tada, H.; Yasuda, F. Metabolites from the Marine Sponge Epipolasis kushimotoensis. Chem. Pharm. Bull. 1985, 33, 1941-1945. [CrossRef]

65. Da Silva, C.C.; Almagro, V.; Zukerman-Schpector, J.; Castellano, E.E.; Marsaioli, A.J. An Easy Route to $(-)-10(R)$-Isothiocyanoaromadendrane and (-)-10(S)-Isothiocyanoalloaromadendrane. J. Org. Chem. 1994, 59, 2880-2881. [CrossRef]

66. Ishiyama, H.; Kozawa, S.; Aoyama, K.; Mikami, Y.; Fromont, J.; Kobayashi, J.I. Halichonadin F and the Cu(I) Complex of Halichonadin C from the Sponge Halichondria sp. J. Nat. Prod. 2008, 71, 1301-1303. [CrossRef] [PubMed]

67. Braekman, J.-C.; Daloze, D.; Stoller, C.; Declercq, J.-P. The Configuration of Palustrol and Related Compounds. Bull. Soc. Chim. Belg. 1989, 98, 869-875. [CrossRef] 
68. Zhang, W.; Gavagnin, M.; Guo, Y.-W.; Mollo, E.; Ghiselin, M.T.; Cimino, G. Terpenoid metabolites of the nudibranch Hexabranchus sanguineus from the South China Sea. Tetrahedron 2007, 63, 4725-4729. [CrossRef]

69. He, H.Y.; Salva, J.; Catalos, R.F.; Faulkner, D.J. Sesquiterpene thiocyanates and isothiocyanates from Axinyssa aplysinoides. J. Org. Chem. 1992, 57, 3191-3194. [CrossRef]

70. Thompson, J.E.; Walker, R.P.; Wratten, S.J.; Faulkner, D.J. A chemical defense mechanism for the nudibranch cadlina luteomarginata. Tetrahedron 1982, 38, 1865-1873. [CrossRef]

71. Simpson, J.S.; Garson, M.J.; Hooper, J.N.A.; Cline, E.I.; Angerhofer, C.K. Terpene Metabolites from the Tropical Marine Sponge Axinyssa sp. nov. Aust. J. Chem. 1997, 50, 1123-1128. [CrossRef]

72. Ciminiello, P.; Fattorusso, E.; Magno, S.; Mayol, L. Sesquiterpenoids Based on the Epi-Maaliane Skeleton from the Marine Sponge Axinella cannabina. J. Nat. Prod. 1985, 48, 64-68. [CrossRef]

73. Burreson, B.J.; Scheuer, P.J.; Finer, J.; Clardy, J. 9-Isocyanopupukeanane, a marine invertebrate allomone with a new sesquiterpene skeleton. J. Am. Chem. Soc. 1975, 97, 4763-4764. [CrossRef]

74. Gulavita, N.K.; De Silva, E.D.; Hagadone, M.R.; Karuso, P.; Scheuer, P.J.; Van Duyne, G.D.; Clardy, J. Nitrogenous bisabolene sesquiterpenes from marine invertebrates. J. Org. Chem. 1986, 51, 5136-5139. [CrossRef]

75. Fusetani, N.; Wolstenholme, H.J.; Matsunaga, S. Co-occurrence of 9-isocyanopupukeanane and its C-9 epimer in the nudibranch phyllidia bourguini. Tetrahedron Lett. 1990, 31, 5623-5624. [CrossRef]

76. Yasman, Y.; Edrada, R.A.; Wray, V.; Proksch, P. New 9-Thiocyanatopupukeanane Sesquiterpenes from the Nudibranch Phyllidia varicosa and Its Sponge-Prey Axinyssa aculeata. J. Nat. Prod. 2003, 66, 1512-1514. [CrossRef] [PubMed]

77. Hagadone, M.R.; Burreson, B.J.; Scheuer, P.J.; Finer, J.S.; Clardy, J. Defense Allomones of the Nudibranch Phyllidia varicosa Lamarck 1801. Helv. Chim. Acta 1979, 62, 2484-2494. [CrossRef]

78. Jaisamut, S.; Prabpai, S.; Tancharoen, C.; Yuenyongsawad, S.; Hannongbua, S.; Kongsaeree, P.; Plubrukarn, A. Bridged Tricyclic Sesquiterpenes from the Tubercle Nudibranch Phyllidia coelestis Bergh. J. Nat. Prod. 2013, 76, 2158-2161. [CrossRef] [PubMed]

79. Karuso, P.; Poiner, A.; Scheuer, P.J. Isocyanoneopupukeanane, a new tricyclic sesquiterpene from a sponge. J. Org. Chem. 1989, 54, 2095-2097. [CrossRef]

80. Pham, A.T.; Ichiba, T.; Yoshida, W.Y.; Scheuer, P.J.; Uchida, T.; Tanaka, J.-I.; Higa, T. Two marine sesquiterpene thiocyanates. Tetrahedron Lett. 1991, 32, 4843-4846. [CrossRef]

81. Nakamura, H.; Kobayashi, J.I.; Ohizumi, Y.; Mitsubishi, K.; Hirata, Y. Novel bisabolene-type sesquiterpenoids with a conjugated diene isolated from the okinawan sea sponge theonella cf. swinhoei. Tetrahedron Lett. 1984, 25, 5401-5404. [CrossRef]

82. Wright, A.D.; Schupp, P.J.; Schrör, J.-P.; Engemann, A.; Rohde, S.; Kelman, D.; de Voogd, N.; Carroll, A.; Motti, C.A. Twilight Zone Sponges from Guam Yield Theonellin Isocyanate and Psammaplysins I and J. J. Nat. Prod. 2012, 75, 502-506. [CrossRef] [PubMed]

83. Sullivan, B.W.; Faulkner, D.J.; Okamoto, K.T.; Chen, M.H.M.; Clardy, J. (6R,7S)-7-amino-7,8-dihydroalpha-bisabolene, an antimicrobial metabolite from the marine sponge Halichondria sp. J. Org. Chem. 1986, 51, 5134-5136. [CrossRef]

84. Li, Z.-Y.; Yu, Z.-G.; Guo, Y.-W. New N-Containing Sesquiterpenes from Hainan Marine Sponge Axinyssa sp. Helv. Chim. Acta 2008, 91, 1553-1558. [CrossRef]

85. Iwashima, M.; Terada, I.; Iguchi, K.; Yamori, T. New Biologically Active Marine Sesquiterpenoid and Steroid from the Okinawan Sponge of the Genus Axinyssa. Chem. Pharm. Bull. 2002, 50, 1286-1289. [CrossRef] [PubMed]

86. Kassuhlke, K.E.; Potts, B.C.M.; Faulkner, D.J. New nitrogenous sesquiterpenes from two Philippine nudibranchs, Phyllidia pustulosa and P. varicosa, and from a Palauan sponge, Halichondria cf. lendenfeldi. J. Org. Chem. 1991, 56, 3747-3750. [CrossRef]

87. Sun, J.-Z.; Chen, K.-S.; Liu, H.-L.; van Soest, R.; Guo, Y.-W. New Epoxy-Substituted Nitrogenous Bisabolene-Type Sesquiterpenes from a Hainan Sponge Axinyssa sp. Helv. Chim. Acta 2010, 93, 517-521. [CrossRef]

88. Liu, W.; Liang, K.-J.; Chiang, C.-Y.; Lu, M.-C.; Su, J.-H. New Nitrogenous Bisabolene-Type Sesquiterpenes from a Formosan Sponge Axinyssa sp. Chem. Pharm. Bull. 2014, 62, 392-394. [CrossRef] [PubMed]

89. Kondempudi, C.M.; Singanaboina, R.; Manchala, N.; Gunda, V.G.; Janapala, V.R.; Yenamandra, V. Chemical Examination of the Sponge Phycopsis sp. Chem. Pharm. Bull. 2009, 57, 990-992. [CrossRef] [PubMed] 
90. Li, C.-J.; Schmitz, F.J.; Kelly, M. New Nitrogenous Bisabolene-Type Sesquiterpenes from a Micronesian Marine Sponge, Axinyssa Species. J. Nat. Prod. 1999, 62, 1330-1332. [CrossRef] [PubMed]

91. Mao, S.-C.; Guo, Y.-W.; van Soest, R.; Cimino, G. New Nitrogenous Bisabolene-Type Sesquiterpenes from a Hainan Sponge Axinyssa aff. variabilis. Helv. Chim. Acta 2007, 90, 588-593. [CrossRef]

92. Cheng, W.; Liu, D.; Zhang, F.; Zhang, Q.; Pedpradab, P.; Proksch, P.; Liang, H.; Lin, W. Formamidobisabolene-based derivatives from a sponge Axinyssa sp. Tetrahedron 2014, 70, 3576-3583. [CrossRef]

93. Tada, H.; Tozyo, T.; Shiro, M. A new isocyanide from a sponge. Is the formamide a natural product? J. Org. Chem. 1988, 53, 3366-3368. [CrossRef]

94. White, A.M.; Pierens, G.K.; Skinner-Adams, T.; Andrews, K.T.; Bernhardt, P.V.; Krenske, E.H.; Mollo, E.; Garson, M.J. Antimalarial Isocyano and Isothiocyanato Sesquiterpenes with Tri- and Bicyclic Skeletons from the Nudibranch Phyllidia ocellata. J. Nat. Prod. 2015, 78, 1422-1427. [CrossRef] [PubMed]

95. Patil, A.D.; Freyer, A.J.; Reichwein, R.; Bean, M.F.; Faucette, L.; Johnson, R.K.; Haltiwanger, R.C.; Eggleston, D.S. Two New Nitrogenous Sesquiterpenes from the Sponge Axinyssa aplysinoides. J. Nat. Prod. 1997, 60, 507-510. [CrossRef] [PubMed]

96. Keyzers, R.A.; Gray, C.A.; Schleyer, M.H.; Whibley, C.E.; Hendricks, D.T.; Davies-Coleman, M.T. Malonganenones A-C, novel tetraprenylated alkaloids from the Mozambique gorgonian Leptogorgia gilchristi. Tetrahedron 2006, 62, 2200-2206. [CrossRef]

97. Sorek, H.; Rudi, A.; Benayahu, Y.; Ben-Califa, N.; Neumann, D.; Kashman, Y. Nuttingins A-F and Malonganenones D-H, Tetraprenylated Alkaloids from the Tanzanian Gorgonian Euplexaura nuttingi. J. Nat. Prod. 2007, 70, 1104-1109. [CrossRef] [PubMed]

98. Zhang, J.-R.; Li, P.-L.; Tang, X.-L.; Qi, X.; Li, G.-Q. Cytotoxic Tetraprenylated Alkaloids from the South China Sea Gorgonian Euplexaura robusta. Chem. Biodivers. 2012, 9, 2218-2224. [CrossRef] [PubMed]

99. Rodríguez, J.; Nieto, R.M.; Hunter, L.M.; Diaz, M.C.; Crews, P.; Lobkovsky, E.; Clardy, J. Variation among known kalihinol and new kalihinene diterpenes from the sponge Acanthella cavernosa. Tetrahedron 1994, 50, 11079-11090. [CrossRef]

100. Chang, C.W.J.; Patra, A.; Roll, D.M.; Scheuer, P.J.; Matsumoto, G.K.; Clardy, J. Kalihinol-A, a highly functionalized diisocyano diterpenoid antibiotic from a sponge. J. Am. Chem. Soc. 1984, 106, 4644-4646. [CrossRef]

101. Patra, A.; Chang, C.W.J.; Scheuer, P.J.; Van Duyne, G.D.; Matsumoto, G.K.; Clardy, J. An unprecedented triisocyano diterpenoid antibiotic from a sponge. J. Am. Chem. Soc. 1984, 106, 7981-7983. [CrossRef]

102. Chang, C.W.J.; Patra, A.; Baker, J.A.; Scheuer, P.J. Kalihinols, multifunctional diterpenoid antibiotics from marine sponges Acanthella sp. J. Am. Chem. Soc. 1987, 109, 6119-6123. [CrossRef]

103. Sun, J.-Z.; Chen, K.-S.; Yao, L.-G.; Liu, H.-L.; Guo, Y.-W. A new kalihinol diterpene from the Hainan sponge Acanthella sp. Arch. Pharmacal Res. 2009, 32, 1581-1584. [CrossRef] [PubMed]

104. Wolf, D.; Schmitz, F.J. New Diterpene Isonitriles from the Sponge Phakellia pulcherrima. J. Nat. Prod. 1998, 61, 1524-1527. [CrossRef] [PubMed]

105. Miyaoka, H.; Shimomura, M.; Kimura, H.; Yamada, Y.; Kim, H.-S.; Yusuke, W. Antimalarial activity of kalihinol A and new relative diterpenoids from the Okinawan sponge, Acanthella sp. Tetrahedron 1998, 54, 13467-13474. [CrossRef]

106. Omar, S.; Albert, C.; Fanni, T.; Crews, P. Polyfunctional diterpene isonitriles from marine sponge Acanthella carvenosa. J. Org. Chem. 1988, 53, 5971-5972. [CrossRef]

107. Xu, Y.; Li, N.; Jiao, W.-H.; Wang, R.-P.; Peng, Y.; Qi, S.-H.; Song, S.-J.; Chen, W.-S.; Lin, H.-W. Antifouling and cytotoxic constituents from the South China Sea sponge Acanthella cavernosa. Tetrahedron 2012, 68, 2876-2883. [CrossRef]

108. Ohta, E.; Ohta, S.; Hongo, T.; Hamaguchi, Y.; Andoh, T.; Shioda, M.; Ikegami, S. Inhibition of Chromosome Separation in Fertilized Starfish Eggs by Kalihinol F, a Topoisomerase I Inhibitor Obtained from a Marine Sponge. Biosci. Biotechnol. Biochem. 2003, 67, 2365-2372. [CrossRef] [PubMed]

109. Bugni, T.S.; Singh, M.P.; Chen, L.; Arias, D.A.; Harper, M.K.; Greenstein, M.; Maiese, W.M.; Concepción, G.P.; Mangalindan, G.C.; Ireland, C.M. Kalihinols from two Acanthella cavernosa sponges: Inhibitors of bacterial folate biosynthesis. Tetrahedron 2004, 60, 6981-6988. [CrossRef] 
110. Fusetani, N.; Yasumuro, K.; Kawai, H.; Natori, T.; Brinen, L.; Clardy, J. Kalihinene and isokalihinol B, cytotoxic diterpene isonitriles from the marine sponge Acanthella klethra. Tetrahedron Lett. 1990, 31, 3599-3602. [CrossRef]

111. Okino, T.; Yoshimura, E.; Hirota, H.; Fusetani, N. Antifouling kalihinenes from the marine sponge Acanthella cavernosa. Tetrahedron Lett. 1995, 36, 8637-8640. [CrossRef]

112. Trimurtulu, G.; Faulkner, D.J. Six New Diterpene Isonitriles from the Sponge Acanthella cavernosa. J. Nat. Prod. 1994, 57, 501-506. [CrossRef] [PubMed]

113. Xu, Y.; Lang, J.-H.; Jiao, W.-H.; Wang, R.-P.; Peng, Y.; Song, S.-J.; Zhang, B.-H.; Lin, H.-W. Formamido-Diterpenes from the South China Sea Sponge Acanthella cavernosa. Marine Drugs 2012, 10, 1445. [CrossRef] [PubMed]

114. Okino, T.; Yoshimura, E.; Hirota, H.; Fusetani, N. New Antifouling Kalihipyrans from the Marine Sponge Acanthella cavernosa. J. Nat. Prod. 1996, 59, 1081-1083. [CrossRef]

115. König, G.M.; Wright, A.D.; Angerhofer, C.K. Novel Potent Antimalarial Diterpene Isocyanates, Isothiocyanates, and Isonitriles from the Tropical Marine Sponge Cymbastela hooperi. J. Org. Chem. 1996, 61, 3259-3267. [CrossRef]

116. Sharma, H.A.; Tanaka, J.-I.; Higa, T.; Lithgow, A.; Bernardinelli, G.; Jefford, C.W. Two New Diterpene Isocyanides from a Sponge of the Family Adocidae. Tetrahedron Lett. 1992, 33, 1593-1596. [CrossRef]

117. Braekman, J.-C.; Daloze, D.; Stoller, C.; Van Soest, R.W.M. Chemotaxonomy of Agelas (Porifera: Demospongiae). Biochem. Syst. Ecol. 1992, 20, 417-431. [CrossRef]

118. Ciavatta, M.L.; Fontana, A.; Puliti, R.; Scognamiglio, G.; Cimino, G. Structures and absolute stereochemistry of isocyanide and isothiocyanate amphilectenes from the Caribbean sponge Cribochalina sp. Tetrahedron 1999, 55, 12629-12636. [CrossRef]

119. Wratten, S.J.; Faulkner, D.J.; Hirotsu, K.; Clardy, J. Diterpenoid isocyanides from the marine sponge hymeniacidon amphilecta. Tetrahedron Lett. 1978, 19, 4345-4348. [CrossRef]

120. Ciavatta, M.L.; Gavagnin, M.; Manzo, E.; Puliti, R.; Mattia, C.A.; Mazzarella, L.; Cimino, G.; Simpson, J.S.; Garson, M.J. Structural and stereochemical revision of isocyanide and isothiocyanate amphilectenes from the Caribbean marine sponge Cribochalina sp. Tetrahedron 2005, 61, 8049-8053. [CrossRef]

121. Molinski, T.F.; Faulkner, D.J.; Van Duyne, G.D.; Clardy, J. Three new diterpene isonitriles from a Palauan sponge of the genus Halichondria. J. Org. Chem. 1987, 52, 3334-3337. [CrossRef]

122. Wattanapiromsakul, C.; Chanthathamrongsiri, N.; Bussarawit, S.; Yuenyongsawad, S.; Plubrukarn, A.; Suwanborirux, K. 8-Isocyanoamphilecta-11(20),15-diene, a new antimalarial isonitrile diterpene from the sponge Ciocalapata sp. Can. J. Chem. 2009, 87, 612-618. [CrossRef]

123. Chanthathamrongsiri, N.; Yuenyongsawad, S.; Wattanapiromsakul, C.; Plubrukarn, A. Bifunctionalized Amphilectane Diterpenes from the Sponge Stylissa cf. massa. J. Nat. Prod. 2012, 75, 789-792. [CrossRef] [PubMed]

124. Avilés, E.; Rodríguez, A.D. Monamphilectine A, a Potent Antimalarial $\beta$-Lactam from Marine Sponge Hymeniacidon sp: Isolation, Structure, Semisynthesis, and Bioactivity. Org. Lett. 2010, 12, 5290-5293. [CrossRef] [PubMed]

125. Avilés, E.; Prudhomme, J.; Le Roch, K.G.; Rodríguez, A.D. Structures, semisyntheses, and absolute configurations of the antiplasmodial $\alpha$-substituted $\beta$-lactam monamphilectines $\mathrm{B}$ and $\mathrm{C}$ from the sponge Svenzea flava. Tetrahedron 2015, 71, 487-494. [CrossRef] [PubMed]

126. Kazlauskas, R.; Murphy, P.T.; Wells, R.J.; Blount, J.F. New diterpene isocyanides from a sponge. Tetrahedron Lett. 1980, 21, 315-318. [CrossRef]

127. Wright, A.D.; Lang-Unnasch, N. Diterpene Formamides from the Tropical Marine Sponge Cymbastela hooperi and Their Antimalarial Activity in Vitro. J. Nat. Prod. 2009, 72, 492-495. [CrossRef] [PubMed]

128. Lamoral-Theys, D.; Fattorusso, E.; Mangoni, A.; Perinu, C.; Kiss, R.; Costantino, V. Evaluation of the Antiproliferative Activity of Diterpene Isonitriles from the Sponge Pseudoaxinella flava in Apoptosis-Sensitive and Apoptosis-Resistant Cancer Cell Lines. J. Nat. Prod. 2011, 74, 2299-2303. [CrossRef] [PubMed]

129. Ciasullo, L.; Cutignano, A.; Casapullo, A.; Puliti, R.; Mattia, C.A.; Debitus, C.; Riccio, R.; Gomez-Paloma, L. A New Cycloamphilectene Metabolite from the Vanuatu Sponge Axinella sp. J. Nat. Prod. 2002, 65, 1210-1212. [CrossRef] [PubMed]

130. Baker, J.T.; Wells, R.J.; Oberhaensli, W.E.; Hawes, G.B. A new diisocyanide of novel ring structure from a sponge. J. Am. Chem. Soc. 1976, 98, 4010-4012. [CrossRef] 
131. Fookes, C.J.R.; Garson, M.J.; MacLeod, J.K.; Skelton, B.W.; White, A.H. Biosynthesis of diisocyanoadociane, a novel diterpene from the marine sponge Amphimedon sp. Crystal structure of a monoamide derivative. J. Chem. Soc. Perkin Trans. 1 1988, 1003-1011. [CrossRef]

132. Corey, E.J.; Magriotis, P.A. Total synthesis and absolute configuration of 7,20-diisocyanoadociane. J. Am. Chem. Soc. 1987, 109, 287-289. [CrossRef]

133. Avilés, E.; Rodríguez, A.D.; Vicente, J. Two Rare-Class Tricyclic Diterpenes with Antitubercular Activity from the Caribbean Sponge Svenzea flava. Application of Vibrational Circular Dichroism Spectroscopy for Determining Absolute Configuration. J. Org. Chem. 2013, 78, 11294-11301. [CrossRef] [PubMed]

134. Wratten, S.J.; Faulkner, D.J. Carbonimidic dichlorides from the marine sponge Pseudaxinyssa pitys. J. Am. Chem. Soc. 1977, 99, 7367-7368. [CrossRef] [PubMed]

135. Simpson, J.S.; Raniga, P.; Garson, M.J. Biosynthesis of dichloroimines in the tropical marine sponge Stylotella aurantium. Tetrahedron Lett. 1997, 38, 7947-7950. [CrossRef]

136. Kehraus, S.; König, G.M.; Wright, A.D. New Carbonimidic Dichlorides from the Australian Sponge Ulosa spongia and Their Possible Taxonomic Significance. J. Nat. Prod. 2001, 64, 939-941. [CrossRef] [PubMed]

137. Musman, M.; Tanaka, J.; Higa, T. New Sesquiterpene Carbonimidic Dichlorides and Related Compounds from the Sponge Stylotella aurantium. J. Nat. Prod. 2001, 64, 111-113. [CrossRef] [PubMed]

138. Brust, A.; Garson, M.J. Dereplication of complex natural product mixtures by 2D NMR: Isolation of a new carbonimidic dichloride of biosynthetic interest from the tropical marine sponge Stylotella aurantium. ACGC Chem. Res. Commun. 2004, 17, 33-37.

139. Simpson, J.S.; Brust, A.; Garson, M.J. Biosynthetic pathways to dichloroimines; precursor incorporation studies on terpene metabolites in the tropical marine sponge Stylotella aurantium. Org. Biomol. Chem. 2004, 2, 949-956. [CrossRef] [PubMed]

140. Wratten; John, D.; Faulkner, S.J.; Van Engen, D.; Clardy, J. A vinyl carbonimidic dichloride from the marine sponge pseudaxinyssa pitys. Tetrahedron Lett. 1978, 19, 1391-1394. [CrossRef]

141. Tanaka, J.; Higa, T. Two New Cytotoxic Carbonimidic Dichlorides from the Nudibranch Reticulidia fungia. J. Nat. Prod. 1999, 62, 1339-1340. [CrossRef] [PubMed]

142. Manzo, E.; Carbone, M.; Mollo, E.; Irace, C.; Di Pascale, A.; Li, Y.; Ciavatta, M.L.; Cimino, G.; Guo, Y.-W.; Gavagnin, M. Structure and Synthesis of a Unique Isonitrile Lipid Isolated from the Marine Mollusk Actinocyclus papillatus. Org. Lett. 2011, 13, 1897-1899. [CrossRef] [PubMed]

143. Dang, H.T.; Lee, H.J.; Yoo, E.S.; Shinde, P.B.; Lee, Y.M.; Hong, J.; Kim, D.K.; Jung, J.H. Anti-inflammatory Constituents of the Red Alga Gracilaria verrucosa and Their Synthetic Analogues. J. Nat. Prod. 2008, 71, 232-240. [CrossRef] [PubMed]

144. Aiello, A.; Fattorusso, E.; Giordano, A.; Menna, M.; Navarrete, C.; Muñoz, E. Clavaminols G-N, six new marine sphingoids from the Mediterranean ascidian Clavelina phlegraea. Tetrahedron 2009, 65, 4384-4388. [CrossRef]

145. Karuso, P.; Scheuer, P.J. Long-chain $\alpha, \omega$-bisisothiocyanates from a marine sponge. Tetrahedron Lett. 1987, 28, 4633-4636. [CrossRef]

146. Capon, R.J.; Skene, C.; Liu, E.H.-T.; Lacey, E.; Gill, J.H.; Heiland, K.; Friedel, T. The Isolation and Synthesis of Novel Nematocidal Dithiocyanates from an Australian Marine Sponge, Oceanapia sp. J. Org. Chem. 2001, 66, 7765-7769. [CrossRef] [PubMed]

147. Li, C.; Blackman, A. Cylindricines C-G, Perhydropyrrolo[2,1-j]quinolin-7-one Alkaloids From the Ascidian Clavelina cylindrica. Aust. J. Chem. 1994, 47, 1355-1361. [CrossRef]

148. Li, C.; Blackman, A. Cylindricines H-K, Novel Alkaloids From the Ascidian Clavelina cylindrica. Aust. J. Chem. 1995, 48, 955-965. [CrossRef]

149. Patil, A.D.; Freyer, A.J.; Reichwein, R.; Carte, B.; Killmer, L.B.; Faucette, L.; Johnson, R.K.; Faulkner, D.J. Fasicularin, a novel tricyclic alkaloid from the ascidian Nephteis fasicularis with selective activity against a DNA repair-deficient organism. Tetrahedron Lett. 1997, 38, 363-364. [CrossRef]

150. Jiménez, C.; Crews, P. Novel marine sponge derived amino acids 13. Additional psammaplin derivatives from Psammaplysilla purpurea. Tetrahedron 1991, 47, 2097-2102. [CrossRef]

151. Iengo, A.; Santacroce, C.; Sodano, G. Metabolism in Porifera. X. On the intermediary of a formamide moiety in the biosynthesis of isonitrile terpenoids in sponges. Experientia 1979, 35, 10-11. [CrossRef] 
152. Hagadone, M.R.; Scheuer, P.J.; Holm, A. On the origin of the isocyano function in marine sponges. J. Am. Chem. Soc. 1984, 106, 2447-2448. [CrossRef]

153. Garson, M.J. Biosynthesis of the novel diterpene isonitrile diisocyanoadociane by a marine sponge of the amphimedon genus: Incorporation studies with sodium [14C]cyanide and sodium [2-14C]acetate. J. Chem. Soc., Chem. Commun. 1986, 35-36. [CrossRef]

154. McClintock, J.B.; Baker, B.J. Marine Chemical Ecology; CRC Press: Boca Raton, FL, USA, 2010; pp. 1-624.

155. Karuso, P.; Scheuer, P.J. Biosynthesis of isocyanoterpenes in sponges. J. Org. Chem. 1989, 54, $2092-2095$. [CrossRef]

156. Parker, W.; Roberts, J.S.; Ramage, R. Sesquiterpene biogenesis. Q. Rev. Chem. Soc. 1967, 21, $331-363$. [CrossRef]

157. Rücker, G. Sesquiterpenes. Angew. Chem. Int. Ed. 1973, 12, 793-806. [CrossRef]

158. Bülow, N.; König, W.A. The role of germacrene D as a precursor in sesquiterpene biosynthesis: Investigations of acid catalyzed, photochemically and thermally induced rearrangements. Phytochemistry 2000, 55, 141-168. [CrossRef]

159. Ugi, I. Isonitrile Chemistry; Academic press: New York, NY, USA, 1971; pp. 1-278.

160. Mayer, A.M.S.; Avilés, E.; Rodríguez, A.D. Marine sponge Hymeniacidon sp. amphilectane metabolites potently inhibit rat brain microglia thromboxane B2 generation. Bioorg. Med. Chem. 2012, 20, 279-282. [CrossRef] [PubMed]

161. Wright, A.D.; McCluskey, A.; Robertson, M.J.; MacGregor, K.A.; Gordon, C.P.; Guenther, J. Anti-malarial, anti-algal, anti-tubercular, anti-bacterial, anti-photosynthetic, and anti-fouling activity of diterpene and diterpene isonitriles from the tropical marine sponge Cymbastela hooperi. Org. Biomol. Chem. 2011, 9, 400-407. [CrossRef] [PubMed]

162. Wright, A.D.; König, G.M.; Angerhofer, C.K.; Greenidge, P.; Linden, A.; Desqueyroux-Faúndez, R. Antimalarial Activity: The Search for Marine-Derived Natural Products with Selective Antimalarial Activity. J. Nat. Prod. 1996, 59, 710-716. [CrossRef] [PubMed]

163. Wright, A.D.; Wang, H.; Gurrath, M.; König, G.M.; Kocak, G.; Neumann, G.; Loria, P.; Foley, M.; Tilley, L. Inhibition of Heme Detoxification Processes Underlies the Antimalarial Activity of Terpene Isonitrile Compounds from Marine Sponges. J. Med. Chem. 2001, 44, 873-885. [CrossRef] [PubMed]

164. Daub, M.E.; Prudhomme, J.; Le Roch, K.; Vanderwal, C.D. Synthesis and Potent Antimalarial Activity of Kalihinol B. J. Am. Chem. Soc. 2015, 137, 4912-4915. [CrossRef] [PubMed]

165. Kodama, K.; Higuchi, R.; Miyamoto, T.; Van Soest, R.W.M. (-)-Axinyssene: A Novel Cytotoxic Diterpene from a Japanese Marine Sponge Axinyssa sp. Org. Lett. 2003, 5, 169-171. [CrossRef] [PubMed]

166. Mao, S.-C.; Manzo, E.; Guo, Y.-W.; Gavagnin, M.; Mollo, E.; Ciavatta, M.L.; van Soest, R.; Cimino, G. New diastereomeric bis-sesquiterpenes from Hainan marine sponges Axinyssa variabilis and Lipastrotethya ana. Tetrahedron 2007, 63, 11108-11113. [CrossRef]

(C) 2016 by the authors; licensee MDPI, Basel, Switzerland. This article is an open access article distributed under the terms and conditions of the Creative Commons by Attribution (CC-BY) license (http://creativecommons.org/licenses/by/4.0/). 